\title{
WestVirginiaUniversity
}

THE RESEARCH REPOSITORY @ WVU

Graduate Theses, Dissertations, and Problem Reports

2019

\section{Defining the Late Style of Johannes Brahms: A Study of the Late Songs}

\author{
Natilan Casey-Ann Crutcher \\ nccrutcher@mix.wvu.edu
}

Follow this and additional works at: https://researchrepository.wvu.edu/etd

Part of the Musicology Commons

\section{Recommended Citation}

Crutcher, Natilan Casey-Ann, "Defining the Late Style of Johannes Brahms: A Study of the Late Songs" (2019). Graduate Theses, Dissertations, and Problem Reports. 3886.

https://researchrepository.wvu.edu/etd/3886

This Dissertation is protected by copyright and/or related rights. It has been brought to you by the The Research Repository @ WVU with permission from the rights-holder(s). You are free to use this Dissertation in any way that is permitted by the copyright and related rights legislation that applies to your use. For other uses you must obtain permission from the rights-holder(s) directly, unless additional rights are indicated by a Creative Commons license in the record and/ or on the work itself. This Dissertation has been accepted for inclusion in WVU Graduate Theses, Dissertations, and Problem Reports collection by an authorized administrator of The Research Repository @ WVU.

For more information, please contact researchrepository@mail.wvu.edu. 
Defining the Late Style of Johannes Brahms: A Study of the Late Songs

\title{
Natilan Crutcher
}

\author{
Dissertation submitted to the \\ College of Creative Arts \\ at \\ West Virginia University \\ In partial fulfillment of the requirements \\ for the degree \\ of
Doctor of Musical Arts
In
Voice Performance

\author{
Hope Koehler, DMA, Chair \\ Evan MacCarthy, Ph.D. \\ William Koehler, DMA \\ David Taddie, Ph.D. \\ General Hambrick, BFA \\ School of Music \\ Morgantown, West Virginia \\ 2019
}

Keywords: Johannes Brahms, Lieder, Late Style

Copyright 2019 Natilan Crutcher 


\begin{abstract}
Defining the Late Style of Johannes Brahms: A Study of the Late Songs
\end{abstract}

\title{
Natilan Crutcher
}

Johannes Brahms has long been viewed as a central figure in the Classical tradition during a period when the standards of this tradition were being altered and abandoned. His resistance to innovation creates some difficulty when trying to pinpoint his "late style", and how he fits into the late style concept. While existing scholarship on Brahms's late style tends to focus on his chamber works, this document focuses on his late Lieder. This document provides a study of Brahms's literary considerations, a comparison of his early and late songs, and a comparison between Brahms and some of his contemporaries. In the end, this study sheds light on when Brahms's late period begins, the characteristics of his late style, the contextual factors that contributed to its development, and how Brahms fits (or does not fit) into the established notions of the concept of the late style in music. 
To my parents, Hezekiah and Tredessa Crutcher,

who were my constant source of encouragement, love, and prayers 


\section{Acknowledgments}

I would like to express my deep gratitude to my research advisor Dr. Evan MacCarthy. Your guidance, support, and encouragement kept me from becoming overwhelmed and allowed me to enjoy the work and dedication that was required to complete this document.

I would like to thank my chair and voice teacher Dr. Hope Koehler for the time, encouragement, patience, and wisdom you have invested in me for the past 6 years. I am grateful for how you have helped me become who I am today, and I will always carry you in my heart.

I would like to thank the rest of my committee members Dr. William Koehler, Dr. David Taddie, and General Hambrick for your council and instruction. Thank you for pushing me to be better and fueling my desire to want more out of my education. 


\section{Table of Contents}

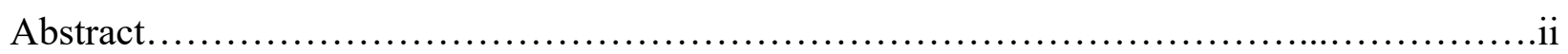

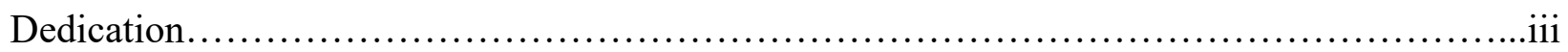

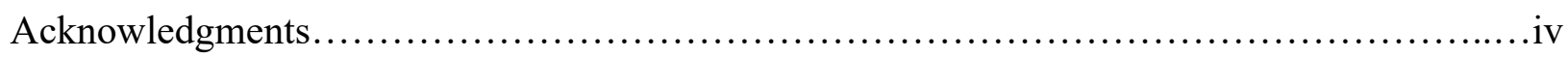

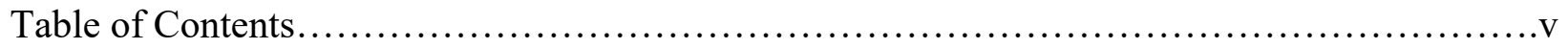

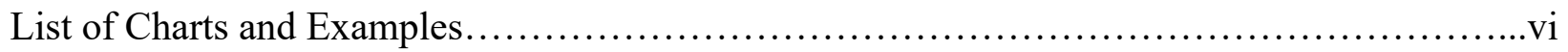

Chapter 1: Brahms and the Concept of Late Style........................................

Chapter 2: Literary Considerations in the Late Lieder of Brahms.......................... 16

Chapter 3: Early and Late Lieder of Brahms: Comparative Case Studies.......................30

Chapter 4: Brahms among Other Lied Composers.....................................60

Chapter 5: Conclusion: Reconsidering Brahms's Late Style.............................90

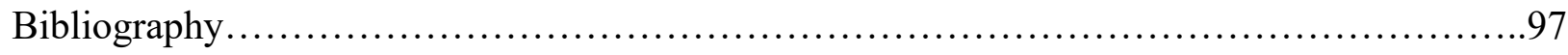




\section{Chapter1}

\section{List of Examples}

Example 1.1 Table of The Late Songs of Brahms....................................... 10

Example 1.2 Table of Textual Selections Discussed in Chapter 2............................14

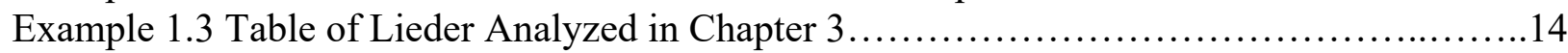

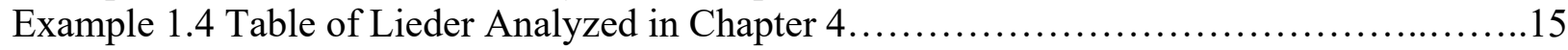

\section{Chapter 2}

Example 2.1 Table of Poets used by Brahms in the Late Lieder...............................18

Example 2.2 Text from Op. 6, no. 4, "Nachtigallen schwingen".............................21

Example 2.3 Text from Opus 94. No. 1, "Mit vierzig Jahren"..............................22

Example 2.4 Text from Op. 94, no. 3, "Mein Herz ist schwer" ...............................23

Example 2.5 Text from Op. 95, no. 4, "Der Jäger" .....................................24

Example 2.6 Text from Vier ernste Gesänge, no. 1, "Denn es gehet"............................26

Example 2.7 Text from Vier ernste Gesänge, no. 2, "Ich wandte mich".......................26

Example 2.8 Text from Vier ernste Gesänge, no. 3, "O Tod, wie bitter bist du".................27

Example 2.9 Text from Vier ernste Gesänge, no. 4, "Wenn ich mit Menschen"................27

\section{Chapter 3}

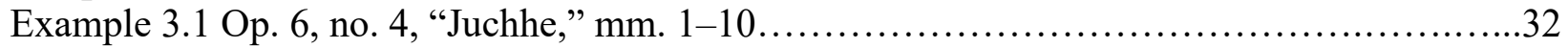

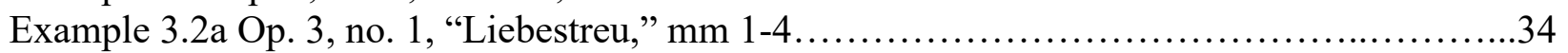

Example 3.2b Op. 6, no. 6, "Nachtigallen schwingen," mm. 1-11........................... 35

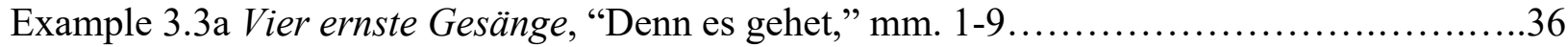

Example 3.3b Vier ernste Gesänge, "Denn es gehet," mm. 30-38..............................

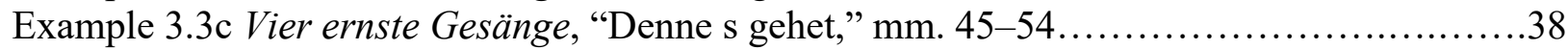

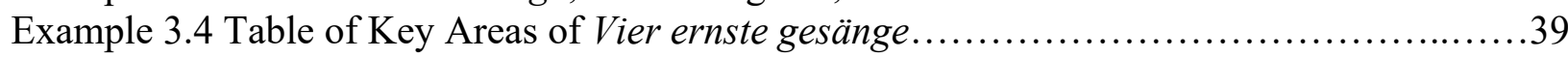

Example 3.5a WoO 32, no. 22, "Marias Wallfahrt" (1858), mm. 1-4 .......................40

Example 3.5b "Marias Wallfahrt" (1894), mm. 1-3.....................................41

Example 3.5c WoO 32, no. 23, "Das Mädchen und der Tod" (1858), mm. 1-3................41

Example 3.5d "Das Mädchen und der Tod" (1894), mm. 1-3............................41

Example 3.6a Op. 95, no. 6, "Mädchenlied" (Am jüngsten Tag), mm. 1-3...................43

Example 3.6b Op. 95, no. 6, "Mädchenlied" (Am jüngsten Tag), mm. 27-31.................43

Examples 3.7a Vier ernste Gesänge, "O Tod, wie bitter bist du," mm. 1-4....................44

Example 3.7b Vier ernste Gesänge, "O Tod, wie bitter bist du," mm. 37-40................44

Example 3.8a Op. 7, no. 1, "Treue Liebe," mm. 8-14 ..................................45

Example 3.8b Op. 95, no. 6, "Mädchenlied," mm. 1-14..................................46

Example 3.8c. Vier ernste Gesänge, "O Tod, O Tod," mm. 1-12 .............................47

Example 3.9 Form Chart of Op. 33, nos. 1, 3, 4, and 6...................................49

Example 3.10 Text of "Nachtigallen schwingen"........................................51

Example 3.11a Op. 6, no. 6, "Nachtigallen schwingen," mm.1-3 ...........................52

Example 3.11b Op. 6, no. 6, "Nachtigallen schwingen" mm. 16-26.........................53

Example 3.11c Op. 6, no. 6, "Nachtigallen schwingen" mm. 48-53..........................54

Example 3.12a Phrase Structure of Op. 72, no. 3, "O kühler Wald"..........................54

Example 3.12b Op. 72, no. 3, "O kühler Wald," mm. 1-5 ...............................55

Example 3.12c Op. 72, no. 3, "O kühler Wald," mm. 18-25 .............................56

Example 3.13a Vier ernste Gesänge, "O Tod, O Tod," mm. 1-7 ..........................57

Example 3.13b Vier ernste Gesänge, "O Tod, O Tod," mm.8-9............................58

Example 3.13c Vier ernste Gesänge, "O Tod, O Tod," mm.29-32............................58 


\section{Chapter 4}

Example 4.1 Liszt, Text from "Ihr Glocken von Marling"...................................68

Example 4.2 Liszt, S. 328, "Ihr Glocken von Marling," score................................70

Example 4.3 Liszt, Text from "Verlassen" .......................................... 73

Example 4.4 Liszt, S. 336, "Verlassen," score...................................... 75

Example 4.5 Timeline of Hugo Wolf's creative output................................... 78

Example 4.6 Wolf, Text from "In dem Schatten meiner locken" .............................81

Example 4.7a Wolf, Spanisches Liederbuch, no.25, "In dem Schatten meiner Locken," score...83

Example 4.8 Wolf, Text from"Alles endet, was entstehet"................................86

Example 4.9 Wolf, Michelangelo-Lieder, no. 21, "Alles endet, was entstehet," mm. 1-14......88 


\section{Chapter 1}

\section{Brahms and the Concept of Late Style}

Brahms represents the disillusioned end of the nineteenth century, Beethoven the more idealistic early years. ${ }^{1}$

Johannes Brahms (1822-1897) has long been viewed as a central figure in the continuation of the Classical tradition of Haydn, Mozart, and Beethoven during a period when the standards of this tradition were altered or even abandoned to allow space for radical innovation. Composers such as Liszt, Wolf, and Wagner, together with their aesthetic allies, rebuked Brahms's contributions as too old-fashioned or lacking in expression. Some scholars, such as Margaret Notley, have observed that this resistance to innovation presents a problem when trying to delineate and define Brahms's late style. ${ }^{2}$ Since there is no dramatic shift, it makes it even harder to pinpoint just when Brahms's late style begins and out of what exactly it grows. Although it is true that Brahms's style did not undergo a dramatic change in his later years, one can find an interesting evolution or refinement to his compositional process that is worthy of closer study.

The existing scholarship on the late works of Brahms has focused primarily on his chamber works for clarinet or the piano works. This may be due to the fact that his commitment to chamber music increased as he grew older. However, there is much to be said about the late style of Brahms through the lens of his later Lieder. Brahms composed approximately 206 songs during his life, in which he explored and developed his fondness for folk song, strophic form, developing variation, and more. This research document will explore and identify characteristics

\footnotetext{
${ }^{1}$ Margaret Notley, Lateness and Brahms: Music and Culture in the Twilight of Viennese Liberalism (New York: Oxford University Press, 2007), 37.

${ }^{2}$ Notley, Lateness and Brahms, 3-14.
} 
of the late style of Johannes Brahms through an analytical study of his Lieder for solo voice and piano composed between 1880 and his death in 1897. This study will define when Brahms's late period begins, the characteristics of his late style, the contextual factors that contributed to its development, and how Brahms fits (or does not fit) into the established notions of the concept of the late style in music.

\section{Defining the Concept of Late Style}

Before defining the concept of Late Style, we should establish first the meaning of "style" that will be used in this document. The term "style" can be used to define something wide or something very narrow. In fashion for example, the 70s "style" might refer to the many features of clothing and accessories that were popular during that time period. In a narrower view of fashion, we could say a cluster ring "style," which simply refers to the feature of arranging or combining multiple gems together into one setting. Both of these examples whether they are used in a broad or narrow sense include features that make up their particular style. Let us look at "Art" and an excerpt of its dictionary definitions to continue our discussion of style.

\section{$\underline{\text { Art- }}$}

I. Skill; its display, application, or expression.

1. Skill in doing something, esp. as the result of knowledge or practice.

2. Skill in the practical application of the principles of a particular field of knowledge or learning; technical skill.

3a. A practical application of knowledge; (hence) something which can be achieved or understood by the employment of skill and knowledge; (in early use also) a body or system of rules serving to facilitate the carry out of certain principles. ${ }^{3}$

If we take into consideration these definitions of what "Art" is, we see that a very wide range of media can fall into this category. We can narrow it further by listing some of these media, e.g.,

${ }_{3}$ Oxford English Dictionary, s.v. "art (n.)," accessed March 28, 2019, http://www.oed.com/. 
literature, theatre, music, design, etc. If we take literature from this list, we can narrow our view even further to plays, stories, novels, lyrics, poetry, etc. Each of these mediums have their own traits or characteristics that categorized them as one or the other. If you picked poetry out of this list, you could create a narrower view of style by distinguishing the different types of poetry there are. In the end, how we view a "style" strongly depends on the defining factors that come with it, or the defining factors that we deem necessary to how we identify it.

David Beard and Kenneth Gloag describe all the different ways that style can be used in music. ${ }^{4}$ They explain that music, in its broadest sense, can represent a style of art, while in a narrow sense, it can be applied to a single note. This single note can carry a tone, dynamic, or timbre that defines its style. "Style" can be applied to the single work of a composer or to the composer in order to define or distinguish their creative process or place among other composers. When used in this sense, style takes into account a composer's use of melody, texture, rhythm, text, harmony, etc. The adopted techniques and forms will grow, evolve or completely change, and these narrower inferences of "style" may combine to depict a broader view of the composer's over-all compositional "style." The term "style" will be used in this document to mean the musical techniques and compositional resources used consistently or at least habitually to compose a work. From this definition of "style," we can consider the meanings of "Late Style."

Discussion and analysis of the concept of Late Style has gone in and out of popularity as it developed over the past few centuries. The most influential revival appeared in 2006 with Edward Said's posthumously published On Late Style: Music and Literature against the Grain. ${ }^{5}$ This work contains a collection of Said's thoughts on the effects of age and mortality on the

${ }^{4}$ For examples, see David Beard and Kenneth Gloag, Musicology: The Key concepts, 2016, 2-4.

${ }^{5}$ Edward W. Said, On Late Style: Music and Literature against the Grain (New York: Vintage Books, 2007). 
creative process of an artist and their works. These thoughts are built on the work of Theodor Adorno (1903-1969), a German philosopher, sociologist, psychologist and composer. Adorno's contribution to late style theory was born and solidified in his study of Beethoven's late music, Beethoven: The Philosophy of Music. There Adorno begins chapter nine:

The maturity of the late works of important artist is not like the ripeness of fruit. As a rule, these works are not well rounded, but wrinkled, even fissured. They are apt to lack sweetness, fending off with prickly tartness those interested merely in sampling them. They lack all that harmony which the classicist aesthetic is accustomed to demand from the work of art, showing more traces of history than of growth. 6

Adorno's perspective came from his study of Beethoven's change in style toward the end of his life. In the midst of Beethoven's deafness, failing health, and family issues, his music became more jagged and unpredictable. Although Adorno continued to see Beethoven as an artist who was fully in command of his medium in his last years, Adorno points out that Beethoven's works seem to abandon many of the well-organized themes that had developed in his youth and middle age, taking on the spirit of unrest or irritability.

In On Late Style, Said responds to Adorno's notions of how age and health contribute or take away from the creative process. ${ }^{7}$ Although Said agrees that the style of some artists can present a lack of "ripeness" as they age, he does present other artists whose styles go in a different direction. In his late plays The Tempest or The Winter's Tale, Shakespeare returns to the forms of romance and parable, which Said points out creates a "sense of resolution" or "wise resignation" within these late plays. On yet another side of the spectrum, Said points out that through Verdi's Othello and Fallstaff, one sees a youthful vigor despite his later age and maturity.

\footnotetext{
${ }^{6}$ Theodor W. Adorno, Beethoven: The Philosophy of Music: Fragments and Texts, ed. Rolf. Tiedemann (Stanford, Calif:: Stanford University Press, 1998), 123.

${ }^{7}$ Said, On Late Style: "Timeliness and Lateness," 6-7.
} 
Over the years, there have been many conflicting views like these surrounding the definition and scope of the late style concept. Some construct their definitions from evidence connected to their favorite artist, then measure others by that paradigm. Others choose to remain objective, not using the late style concept to define an artist's last years in a positive or negative light, but simply as a tool to put their final years into perspective. In a study by Michael and Linda Hutcheon, the issues of pre-conceived notions of a late style is addressed thoroughly. ${ }^{8}$ They describe how "Late style" as an English term was combined from the German Spätstil (late style) and Altersstil (individual old-age style). ${ }^{9}$ Due to this combination, the English designation of "late style" has become an extremely vague expression. One could choose to associate "late style" with old age, while others would choose to view it as the last works of an artist not taking into account the age they died. In the midst of this vagueness, the concept has come to describe the last works of an artist regardless of the age that they died. At the beginning of the article, the Hutcheons point out two very important factors. One is the tendency to place more worth on a work when we indeed know that it is the final one. Although there may be groundbreaking and culminating achievements within that work, one can go too far to the point of fashioning stylistic features that are not present or that can be explained with other means. The second tendency and title of the article is the matter of ageism. By using the term late style, some scholars have put the "late style" concept into a box of preconceived notions that suit them. Hutcheon and Hutcheon explain this idea thus:

We wish to show how the universalized (rather than individualize) deployment of the term-whether positively or negatively- has led not only to falsifications, to elisions of distinction and differences, but also to explicit or implicit denigrations of later-life creativity that are, in fact ageist. ${ }^{10}$

\footnotetext{
${ }^{8}$ Michael Hutcheon and Linda Hutcheon, "Late Style(s): The Ageism of the Singular," 2012.

${ }^{9}$ Hutcheon and Hutcheon, "Late Style(s)", 1.

${ }^{10}$ Hutcheon and Hutcheon,"Late Style(s)", 3.
} 
They point out that a late style analysis of a composer's life and works will serve us best if we remember to remain open and objective. It is through this thought process that we will here examine the late style of Johannes Brahms.

\section{Brahms's Biography in His Late Years}

Malcolm MacDonald has addressed two influential aspects of Brahms's "final phase."11 One of these aspects is a change of scenery during most of his summers. During the most creative stage of his compositional process, when the sketching or drafting of his works took place, Brahms preferred to be in rural places with majestic views of lakes or mountains. From 1877 to the end of his life, he spent most of his summers at resorts and hideaways of Rügen, Pörtschach, the Upper Austrian resort of Ischl in the Salzakammergut, Pressbaum, Wiesbaden, the village of Mürzzuschlag in the Styrian Alps, and many other places. The second aspect that cruelly shadowed his late years was an accumulation of losses within his circle of friends and family. From 1877 to 1894, Brahms lost over a dozen friends, family members, and colleagues, and by 1892 , he had outlived all of his blood relatives. Many scholars, like MacDonald, believe that this experience of profound loss in his last twenty years certainly affected his outlook on life and mortality, and that this may be reflected in his late works. The impact of this second aspect of his late years on the selection of texts for his late Lieder will be explored in the next chapter.

\footnotetext{
${ }^{11}$ Malcolm MacDonald, Brahms, 1st American ed., Master Musicians Series (New York: Schirmer Books, 1990), 292-296.
} 


\section{Scholarship on Late Brahms}

In Lateness and Brahms: Music and Culture in the Twilight of Viennese Liberalism, Margaret Notley sheds light on how Brahms was seen by his contemporaries. ${ }^{12}$ Notley explains that in the years between the First and Second World Wars, scholars were attempting to bring order to the musical heritage of the eighteenth and nineteenth century, in a period known to some as the middle-class era, when a rise of liberalism and free market capitalism had dominated Europe. ${ }^{13}$ From this effort by historians to bring order and understanding to these events, scholars of music came to recognize Brahms's importance as a crucial representative of that period in its late phase. Instead of conforming to new trends, scholars saw him trying to force meaning back into many of the tonal procedures of Classical forms. Brahms's lack of conformity as new trends took their place in history makes his late period harder to pinpoint. However, we are given more clues to aid our endeavor through his chamber and orchestral works.

One major work that marked a turning point in Brahms career was the Third Symphony (Op. 90, 1883). MacDonald argues that the last dozen years of Brahms creative life brought no drastic change of style:

The last dozen years or so of Brahms's creative life brought no startling change of style- but his tendency, from at least the mid-1860s onward, always to create an organic unity, with every grater motivic economy and tonal fluidity yet increasing potency of ideas, had solidified by now into a 'late manner' which combined a masterly concision of structure with remarkable freedom and richness of thought. ${ }^{14}$

MacDonald believes that Brahms's Third Symphony was a great illustration of these tendencies. He explained that Brahms's contemporaries of the time reported hearing a new melodiousness in the Third Symphony and his First String Quintet in F Major (Op. 88, 1882).

\footnotetext{
12 Notley, Lateness and Brahms, ch 2.

${ }^{13}$ Notley, Lateness and Brahms, 6.

${ }^{14}$ MacDonald, Brahms, 302.
} 
After the Third Symphony, critics saw that Brahms was drawing from his great lyric talent and creating a work that offered pleasure not only to the expert through its artistic working out, but also to the ears of a naïve listener. There were many different views toward this more lyric and simplistic approach. While some critics praised the change of approach, others viewed it as a symptom of decline. Richard Pohl felt that while the change in style made his music more accessible, it was also made it less distinguished than his earlier chamber works. Notley wrote that in his 1887 review, Bernhard Vogel praised Brahms for ending his tendency of "addressing the listener with tonal puzzles, but rather with intimate heart-winning melodic openness." ${ }^{15} \mathrm{He}$ linked this to a possible solitary optimism in the composer's outlook. Vogel would later take a negative view towards Brahms's attempt of a more popular style. He later suggested that Brahms had compromised his integrity with the style change. Vogel explained that "the most characteristic Brahms is understood by only a few which is the problem with his individuality."16

As it has previously been stated, most existing scholarship on Braham's late style focuses on his chamber works. In Margaret Notley's study of Brahms's Second Cello Sonata in F Major (Op. 99, 1886), she discusses and demonstrates clearly his adaptation of sonata form. ${ }^{17}$ After the year 1840, Notley argues that sonata form was no longer a free development of stylistic principles, but an attempt to reach greatness through imitation of classical forms. Notley singles out Adornos's 1934 essay where he acknowledges that the sonata form had changed but argues that Brahms understood how to work within the changes. One example he points out is in his $\mathrm{F}$ Major Cello Sonata where Brahms creates a design that avoids every firmly imprinted shape. ${ }^{18}$ This flexibility in which Brahms uses sonata procedures refutes characterizations of his formal

\footnotetext{
${ }^{15}$ Notley, Lateness and Brahms, 48.

${ }^{16}$ Notley, Lateness and Brahms, 48.

${ }^{17}$ Notley, Lateness and Brahms, 76-77.

${ }^{18}$ Notley, Lateness and Brahms, 77.
} 
approach as academic. This relaxation of formal procedures and models is one of the themes that embodies the works of his late years.

\section{Defining the Repertory of the Late Songs of Brahms}

If we look back at the First String Quintet in F Major (Op. 88, 1882), the Third Symphony (1883) and the Second Cello Sonata in F Major (Op. 99, 1886), which have been highlighted by Notley as examples from Brahms's late works, we see a possible trend of changed starting to occur at least by the early 1880 s. Let us now change course and venture into the world of his art songs. If we analyze the output of Brahms art songs, we see that there is a gap between the Opp. 72 (1876-1877) and 84 (1881). This is evidently the evidence of a break he took away from Lieder to work on other works. When Brahms returns to song in Op. 84, he continues composing Lieder until the end of his life. From this evidence and the slight stylistic changes that appears with Op. 84, we will examine Opp. 84-121 as his late songs. 
Example 1.1 Table of the Late Songs of Brahms ${ }^{19}$

\begin{tabular}{|c|c|c|c|}
\hline Op.\# & $\underline{\text { Title }}$ & Poet/Text Source & $\begin{array}{l}\text { Composition } \\
\text { Date }\end{array}$ \\
\hline 84 & $\begin{array}{ll}\text { 1. } & \text { Sommeraben } \\
\text { 2. } & \text { Der Kranz } \\
\text { 3. } & \text { In den Beeren } \\
\text { 4. } & \text { Vergebliches Ständchen } \\
\text { 5. Spannung }\end{array}$ & $\begin{array}{l}\text { Hans Schmidt } \\
\text { Schmidt } \\
\text { Schmidt } \\
\text { Anon. (trans. Lower-Rhenish, and } \\
\text { Zuccalmaglio) } \\
\text { Anon. (trans. Lower-Rhenish, and } \\
\text { Zuccalmaglio) }\end{array}$ & $\begin{array}{l}1881 \\
1881 \\
1881 \\
1882\end{array}$ \\
\hline 85 & $\begin{array}{ll}\text { 1. } & \text { Sommerabend } \\
\text { 2. } & \text { Mondenschein } \\
\text { 3. } & \text { Mädchenlied } \\
\text { 4. } & \text { Ade! } \\
\text { 5. } & \text { Frühlingslied } \\
\text { 6. } & \text { In Waldeseinsamkeit }\end{array}$ & $\begin{array}{l}\text { Heinrich Heine } \\
\text { Heine } \\
\text { Anon., Serbian (trans. S. Kapper) } \\
\text { Anon., Czech (trans. S. Kapper) } \\
\text { Emanuel Geibel } \\
\text { Karl Lemcke }\end{array}$ & $\begin{array}{l}1878 \\
1878 \\
1878 \\
1882 \\
1878 \\
1878 \\
\end{array}$ \\
\hline 86 & $\begin{array}{ll}\text { 1. } & \text { Therese } \\
\text { 2. } & \text { Feldeinsamkeit } \\
\text { 3. Nachtwandler } \\
\text { 4. Über die Heide } \\
\text { 5. } & \text { Versunken } \\
\text { 6. } & \text { Todessehnen } \\
\end{array}$ & $\begin{array}{l}\text { Gottfried Keller } \\
\text { Hermann Allmers } \\
\text { Max Kalbeck } \\
\text { Theodor Storm } \\
\text { Felix Schumann } \\
\text { Max von Schenkendorf } \\
\end{array}$ & $\begin{array}{l}1878 \\
1882 \\
1877 \\
1882 \\
1878 \\
1878 \\
\end{array}$ \\
\hline 91 & $\begin{array}{l}\text { 1. Gestillte Sehnsucht } \\
\text { 2. Geistliches Wiegenlied }\end{array}$ & $\begin{array}{l}\text { Friedrich Rückert } \\
\text { Lope de Vega (trans. Geibel) }\end{array}$ & $\begin{array}{l}1884 \\
1863-4 \\
\end{array}$ \\
\hline 94 & $\begin{array}{ll}\text { 1. } & \text { Mit vierzig Jahren } \\
\text { 2. } & \text { Steig auf, geliebter Schatten } \\
\text { 3. } & \text { Mein Herz ist schwer } \\
\text { 4. } & \text { Sapphische Ode } \\
\text { 5. } & \text { Kein Haus, keine Heimat }\end{array}$ & $\begin{array}{l}\text { Friedrich Rückert } \\
\text { Friedrich Halm } \\
\text { Emanuel Geibel } \\
\text { Hans Schmidt } \\
\text { Halm } \\
\end{array}$ & $\begin{array}{l}1883 \\
1883-4 \\
1883-4 \\
1883-4 \\
1883-4 \\
\end{array}$ \\
\hline 95 & $\begin{array}{ll}\text { 1. } & \text { Das Mädchen } \\
\text { 2. } & \text { Bei dir sind meine Gedanken } \\
\text { 3. } & \text { Beim Abschied } \\
\text { 4. } & \text { Der Jäger } \\
\text { 5. Vorschneller Schwur } \\
\text { 6. Mädchenlied } \\
\text { 7. } \text { Schön war, das ich dir weihte }\end{array}$ & $\begin{array}{l}\text { Anon., Serbian (trans. S. Kapper) } \\
\text { Friedrich Halm } \\
\text { Halm } \\
\text { Halm } \\
\text { Anon.,Serbian (trans. S. Kapper) } \\
\text { Anon., Italian (trans. P. Heyse) } \\
\text { Georg Daumer (from the Turkish) }\end{array}$ & $\begin{array}{l}1883 \\
1884 \\
1884 \\
1884 \\
1884 \\
1884 \\
1883-4 \\
\end{array}$ \\
\hline 96 & $\begin{array}{ll}\text { 1. } & \text { Der Tod, das ist die kühle Nacht } \\
\text { 2. Wir wandelten } \\
\text { 3. Es schauen die Blumen } \\
\text { 4. } \\
\end{array}$ & $\begin{array}{l}\text { Heinrich Heine } \\
\text { Georg Daumer (from the Magyar) } \\
\text { Heine } \\
\text { Heine }\end{array}$ & $\begin{array}{l}1884-5 \\
1884-5 \\
1884-5 \\
1884-5 \\
\end{array}$ \\
\hline 97 & $\begin{array}{ll}\text { 1. } & \text { Nachtigall } \\
\text { 2. } & \text { Auf dem Schiffe } \\
\text { 3. } & \text { Entführung } \\
\text { 4. } & \text { Dort in den Weiden } \\
\text { 5. } & \text { Komm Bald } \\
\text { 6. } & \text { Trennung } \\
\end{array}$ & $\begin{array}{l}\text { Christian Reinhold } \\
\text { Reinhold } \\
\text { Willibald Alexis } \\
\text { Anonymous } \\
\text { Klaus Groth } \\
\text { Anonymous. Swabian } \\
\end{array}$ & $\begin{array}{l}1885 \\
1885 \\
1885 \\
1885 \\
1885 \\
1885 \\
\end{array}$ \\
\hline 105 & $\begin{array}{ll}\text { 1. } & \text { Wie Melodien zieht es mir } \\
\text { 2. Immer leiser wird mein.. } \\
\text { 3. Klage } \\
\text { 4. Auf dem Kirchhofe } \\
\text { 5. }\end{array}$ & $\begin{array}{l}\text { Klaus Groth } \\
\text { Hermann Lingg } \\
\text { Anonymous. (Lower Rhine) } \\
\text { Detlev von Liliencron } \\
\text { Karl Lemcke }\end{array}$ & $\begin{array}{l}1886 \\
1886 \\
1886 \\
1886 \\
1886\end{array}$ \\
\hline
\end{tabular}

${ }^{19}$ Eric. Sams, The Songs of Johannes Brahms (New Haven, Conn.: Yale University Press, 2000); George S. Bozarth and Walter Frisch, Brahms, Johannes (Oxford University Press, 2001), 


\begin{tabular}{|l|ll|l|l|}
\hline 106 & 1. & Ständchen & Franz Kugler & 1888 \\
& 2. & Auf dem See & Christian Reinhold & 1885 \\
& 3. & Es hing der Reif & Klaus Groth & 1888 \\
& 4. & Meine Lieder & Adolf Frey & 1888 \\
& 5. & Ein Wanderer & Reinhold & 1885 \\
\hline 107 & 1. & An die Stolze & Paul Flemming & 1886 \\
& 2. & Salamander & Karl Lemcke & 1888 \\
& 3. & Das Madchen spricht & Otto Gruppe & 1886 \\
& 4. Maienkätzchen & Detlev von Liliencron & 1887 \\
& 5. & Mädchenlied & Paul Heyse & 1888 \\
\hline 121 & 1. & Denne s gehet dem Menschen & Bible: Ecclesiastes iii.19-22 & 1896 \\
& 2. & Ich wandte mich, und sahe & Bible: Ecclesiastes iv.1-3 & \\
& 3. & O Tod, o Tod, wie bitter bist du & Apocrypha: Ecclesiasticus xii.1-2 & \\
& 4. Wenn ich mit Menschenund & Bible: 1 Corinthians xiii.1-4, 12-13 & \\
\hline
\end{tabular}

\section{Scholarship on the Late Songs of Brahms}

As scholars study and analyze the late songs and instrumental works of Brahms, there is one message or point that rings true across the scholarship: there was not a significant change in the art songs of Brahms composed later in his life. In his Guide to the Solo Songs of Brahms, Lucien Stark states that "The youthful songs exhibit a certain romantic excess but are already clearly the work of a master; maturity brought not so much a change of approach as a continuing process of refinement and concertation.." ${ }^{20}$ Brahms developed his compositional skills, and mastery at a young age. Stark claims that these skills just continued and expanded to a degree as he got older. He does go on to mentioned that his early arrangements of folk songs were simple and at times naïve. They could easily be compared to other folk songs that were composed during the time. However, as he matured in his skill, they began to assume more importance and independence.

One aspect of Brahms's late song output that is a popular subject of analysis is his textual choices. There are bigger issues and discussions about Brahms's overall text choices that will be discussed in chapter 2, but for now we will explore what is said about his later text choices.

\footnotetext{
${ }^{20}$ Lucien Stark, A Guide to the Solo Songs of Johannes Brahms (Bloomington: Indiana University Press, 1995), 1.
} 
When it comes to his Lieder in his late years, Brahms starts to introduce the subject of death and a contemplation of life. From Op. 86 to the end of his song writing, you start to see a lot more poetry speaking of death, life and loss of time. Stark points out that it seems that Brahms shifts to finding solace in "contemplating the path that lies at journeys end." ${ }^{21}$ He uses Op. 94, no. 1, "Mit vierzig Jahren" (At Forty), a text by Friedrich Rückert, as a key example. ${ }^{22}$ Rückert, himself at middle age, assesses his life and finds strength in the belief that the hardest part of the journey is nearly completed. This is made significant because up until this point we do not see poetry in Brahms's Lieder that engages as overtly with death and contemplation of life. His use of death in his texts comes to a peak with the Vier ernste Gesänge, Op.121. Ein Duetsches Requiem (1868) is an earlier significant case of Brahms drawing on Biblical texts concerning death and life. In his dissertation on Op. 121, Daniel Beller-McKenna compares the Biblical excerpts of Ein Deutsches Requiem with those used in the Vier ernste Gesänge. ${ }^{23}$ Beller-McKenna states that the consoling image of death offered by the third song of Vier ernste Gesänge, "O Tod", is less comforting than the image of death in his Ein Deutsches Requiem. Beller-McKenna wrote "Martin Meiser questioned whether Brahms would have chosen the same "God-trusting" texts for his Requiem of 1868 had he written the piece at the end, rather than the middle of his life." 24 Meiser felt that perhaps this was the result of Brahms's greater pessimism in his view toward life and proposes that nos. 1 and 2 of Vier Ernste Gesänge are far more pessimistic than any of the text that is found in the Requiem. We will explore the text from both of these works and Meiser's view on Brahms late text choices in more detail in Chapter 2.

\footnotetext{
${ }^{21}$ Stark, A Guide to the Solo Songs, 278.

${ }^{22}$ Stark, A Guide to the Solo Songs, 277.

${ }^{23}$ Daniel Beller-McKenna, "Brahms on Schopenhauer: The 'Vier Ernste Gesänge', Op. 121, and Late NineteenthCentury Pessimism” (Ph.D., diss, Harvard University, 1994).

${ }^{24}$ Beller-MacKenna, "Brahms on Schopenhauer," 182.
} 
Text is a one of the most significant subjects that is talked about when scholars think about Brahms's late song style, but there are other subjects that are discussed as well. One theme that is addressed by Alex Ross is about how Brahms's secret weapon was his use of rhythm. ${ }^{25} \mathrm{He}$ states that nineteenth-century classical music was not prized for its rhythmic invention, but Brahms had no problem pushing against standard uses of rhythm. This is why many scholars believe that he was so devoted to folk songs. He also ventured into the Hungarian dance style and produced his Zigeunderlieder (Op. 103 and 112, nos. 3-6) as well their arrangement for solo voice and piano. Gypsy music fascinated Brahms throughout his life and called upon its influence specifically at the lighter times of his life. Ross explains that within the Gypsy songs you see his love of dance like rhythm in the $2 / 4$ csárdás style of the Hungarian dance, and the changes of tempo, but not meter. Ross goes on to point out that his mature music is rife with syncopating accents, themes that hang back a beat or jump ahead, jaunty polyrhythms of three against two or three against four. ${ }^{26} \mathrm{He}$ tried to create tension or a tug of war between the perceived rhythm of the phrase, and the underlying metric pulse. His rhythmic invention follows and grows with him throughout his life.

To continue with our study of Brahms's late songs we will start in chapter 2 with a deeper analysis into Brahms's literary choices as it pertains to poets, setting, and subjects calling on examples listed in Example 1.2. We will use these examples to explore and analyze how and why his literary choices changed in his late songs.

\footnotetext{
${ }^{25}$ Alex Ross, "Blessed Are the Sad: Late Brahms," in Listen to This (New York, NY: Farrar, Straus, \& Giroux, 2010), 293-311.

${ }^{26}$ Ross, "Blessed Are the Sad," 315-316.
} 
Example 1.2 Table of Textual Selections Discussed in Chapter 2.

\begin{tabular}{|l|l|l|}
\hline Opus \# & Title & Poet/Source \\
\hline Opus 6/6 & "Nachtigallen schwingen" & August Heinrich Hoffmann von Fallersleben \\
\hline Opus 94/1 & "Mit vierzig Jahren" & Freidrich Rückert \\
\hline Opus 94/3 & "Mein Herz ist schwer" & Emanuel Geibel \\
\hline Opus 95/4 & "Der Jäger" & Friedrich Halm \\
\hline Opus 121 & Vier ernste gesänge & \\
\hline 1. & "Denn es gehet" & Ecclesiastes 3:19-22 \\
\hline 2. & "Ich wandte mich und sahe" & Ecclesiastes 4;1-3 \\
\hline 3. & "O Tod, wie bitter bist du" & Ecclesiasticus 41;1-2 \\
\hline 4. & "Wenn ich mit Menschen" & 1 Corinthians 13:1-3,12-13 \\
\hline
\end{tabular}

In chapter 3, we will explore what scholars have to say about the differences between Brahms's early and later songs. Looking at examples from the list in Example 1.3, we will trace the evolution of his use of melody, harmony, accompaniment, dynamics, and more in a comparison of his early and late songs.

Example 1.3 Table of Lieder Analyzed in Chapter 3.

\begin{tabular}{|l|l|l|}
\hline Opus \# & Title & Composition Date \\
\hline Opus 6/4 & "Juchhe" & 1852 \\
\hline Opus 3/1 & "Liebestreu" & 1853 \\
\hline Opus 6/6 & "Nachtigallen schwingen" & 1853 \\
\hline Opus 121/1 & "Denn es gehet" & 1896 \\
\hline Opus 121/3 & "O tod, O tod" & 1896 \\
\hline WoO 32/22 & "Marias Wallfahrt" & 1858 \\
\hline WoO 33/14 & "Marias Wallfahrt" & 1894 \\
\hline WoO 32/23 & "Das Mädchen und der Tod" & 1858 \\
\hline WoO33/21 & "Das Mädchen und der Tod" & 1894 \\
\hline Opus 95/6 & "Mädchenlied" & 1884 \\
\hline Opus 7/1 & "Treue Liebe" & 1852 \\
\hline Opus 72 & O Kühler wald & 1877 \\
\hline
\end{tabular}

In chapter 4, we will explore how Brahms's songs fits into the nineteenth century, comparing his late style with the styles of Franz Liszt and Hugo Wolf through a discussion of the songs and texts listed in Example 1.4. 
Example 1.4 Table of Lieder Analyzed in Chapter 4.

\begin{tabular}{|l|l|l|l|}
\hline Composer & Title & Date & Poet \\
\hline Franz Liszt & "Ihr Glocken von Marling" & 1874 & Emil Kuh \\
& "Verlassen" & 1880 & G. Michell \\
\hline \multirow{2}{*}{ Hugo Wolf } & "In dem Schatten meiner locken" & 1889 & Paul Heyse and Emanuel Geibel \\
& "Alles endet, was enstehet" & 1897 & Michelangelo Buonarroti \\
\hline
\end{tabular}

At the end of this exploration, chapter 5 will summarize what these analyses of text and music might yielded about the late style of Brahms as we know it, especially as it pertains to his Lieder, how this analysis speaks to the concept of late style, and how the late style concept and analysis can help us as scholars and performers. 


\section{Chapter 2}

\section{Literary Considerations in the Late Lieder of Brahms}

Love was, for Brahms, the greatest of the spiritual attributes that he addressed through the Bible..., for it was the one that allowed him to overcome his own melancholy and the cultural pessimism that he could no longer abide near the end of his life as he returned in so many way to the Romanticism of his youth. ${ }^{27}$

When it comes to song texts, Brahms stands out for his peculiar and indiscriminate way of choosing them. Lucien Stark, Carol Kimball, and Lorraine Gorrell all point out that Brahms's poetic choices and treatment were not always seen in a positive light. ${ }^{28}$ The text would often lead to unevenness in the phrases of his melodies or incorporate accents in strange places. His avoidance of the great lyrics sets by Schubert, Schumann, and Wolf and his carelessness in the declamation of his texts caused him to be put into a second-class category when it came to text setting. Some even saw him as a composer whose abilities declined as he moved into the realm of text and drama. This of course is a shallow observation that does not take into consideration the creative reasoning behind it. Hans Gal argues that there is actually a deeper reason for his text choices. ${ }^{29}$

For many composers of song, a significant aspect of a poem is its subject and the quality of its textual declamation, one that might follow a natural rhythm and accentuation of human speech. Brahms however, had an individual way of reading texts. When Brahms was composing his songs, Brahms honed in on the lyrical feeling of the poetry. He wanted the poems to appeal to his imagination and better yet, create no resistance to his creative process. He did not want to be

\footnotetext{
${ }^{27}$ Daniel Beller-MacKenna, "Brahms, the Bible, and Post-Romanticism: Cultural Issues in Johannes Brahms's Later Settings of Biblical Texts, 1877-1896" (Harvard University, 1994), 223.

${ }^{28}$ Carol Kimbal, Song: A Guide to Art Song Style and LIteratrue. Revised Editon. Milwaukee, WI: Hal Leonard Corporation, 2005.; Stark, A Guide to the Solo Songs, ; Lorraine Gorrell, The Nineteenth-Century German Lied. (Portland, Or.: Amadeus Press, 1993).

${ }^{29}$ Hans Gál, Johannes Brahms: His Work and Personality (London: Severn House, 1975), 185.
} 
held hostage to tight and even phrases but wanted the ability and freedom to create as much expression in the melody as he desired. It is this lack of poetic concerns that has alienated and caused him to be contrasted with Hugo Wolf. Wolf, on the other hand, refused to compromise his text selections for his songs. From the beginning of his first published songs, Brahms was aware of the criticism of his declamation. This speaks more to the fact that his faulty declamation was a conscious decision.

Sue Okuda observes that the lack of quality in his text choice and settings did not mean that he was lacking in understanding or consideration of literature. ${ }^{30}$ There is a fair amount of evidence to suggest Brahms at times promoted a careful attention to text declamation, as he was very academic in his study and reading of poetry. According to his student Gustave Jenner, Brahms required him to have a detailed understanding of the text. ${ }^{31}$ Brahms recommended that Jenner recite the text, then analyze the form and meter, paying close attention to the location of the pauses. It is evident that Brahms had a great appreciation and respect for the art of poetry. However, the expressiveness was a driving force in his Lieder, compelling him to overrule the poetic form to the point of often disregarding his own teachings about melodic structure and declamation. This discipline followed Brahms throughout his song-writing career.

When it came to poets, Brahms considered more than just the major poets for his songs. He often avoided texts that had already been set to music, and he had a strict discipline when it came to the possible ranges within the text setting. For Brahms, it seemed pointless to set texts, which were already complete within themselves. This is another reason we see him use less of the great lyrics that other composers of his generation used throughout his career. Each of his

\footnotetext{
${ }^{30}$ Sue S Okuda, "Brahm's Late Song Style:The Vier Ernste Gesänge, Op.121” (M.A. thesis, California State University, 1981), 17.

${ }^{31}$ Rufus E. Hallmark, German Lieder in the Nineteenth Century, Second edition., Routledge Studies in Musical Genres (New York: Routledge, 2010), 144.
} 
sets could feature texts from as many as six different poets. His most frequently used poets throughout his career were Klaus Groth (1819-1899), Max Kalbeck (1850-1921), Carl Lemcke (1831-1913), Friederich Halm (1806-1871), Hans Schmidt (1854-1923), Josef Wenzig (18071876), Carl Candidus (1817-1872), and G.F. Daumer (1800-1875). In the songs of his late years, one finds him drawing on over twenty different literary sources. The most frequently used being Heine, Kapper, F. Halm, and Reinhold. We also see him call on Scriptures, from Ecclesiastes, Ecclesiasticus (Sirach) ${ }^{32}$ and 1 Corinthians, in his final work for voice, Vier ernste Gesänge.

Brahms was never exclusive with his text choices from the beginning to the end of his career, choosing texts based on the form, flexibility, and inspiration that they provided.

\section{Example 2.1 Table of Poets used by Brahms in the Late Lieder ${ }^{33}$}

\begin{tabular}{|l|l|}
\hline Poet & Birth and Death Dates \\
\hline Hans Schmidt & $1856-?$ \\
\hline Anton Willhelm Florentin von Zuccalmaglio & $1803-1869$ \\
\hline Heinrich Heine & $1797-1856$ \\
\hline Siegfried Kapper & $1821-1879$ \\
\hline Emanuel Geibel & $1815-1884$ \\
\hline Karl Lemcke & $1831-1913$ \\
\hline Gottfried Keller & $1819-1890$ \\
\hline Hermann Allmers & $1821-1901$ \\
\hline Max Kalbeck & $1850-1921$ \\
\hline Theodor Storm & $1817-1888$ \\
\hline Felix Schumann & $1854-1879$ \\
\hline Max von Schenkendorf & $1783-1817$ \\
\hline Friedrich Rückert & $1788-1866$ \\
\hline Emanuel Geibel & $1815-1884$ \\
\hline Friedrich Halm & $1806-1871$ \\
\hline Paul von Heyse & $1830-1914$ \\
\hline Georg Friedrich Daumer & $1800-1875$ \\
\hline Christian Reinhold Köstlin & $1813-1856$ \\
\hline Willibald Alexis( Wilhelm Häring) & $1798-1871$ \\
\hline Klaus Groth & $1819-1899$ \\
\hline Hugo Conrat & $1845-1906$ \\
\hline
\end{tabular}

\footnotetext{
${ }^{32}$ The Wisdom of Jesus the Son of Sirach is a Deuterocanonical Scripture recognized by the Roman Catholic, Greek Orthodox, and Russian Orthodox Churches.

${ }^{33}$ Stark, A Guide to the Solo Songs, 242-252.
} 


\begin{tabular}{|l|l|}
\hline Hermann Lingg & $1820-1905$ \\
\hline Lower Rhine & $?$ \\
\hline Detlev von Liliencron & $1844-1909$ \\
\hline Franz Kugler & $1808-1858$ \\
\hline Adolf Frey & $1855-1920$ \\
\hline Paul Flemmling & $1609-1640$ \\
\hline Otto Friedrich Gruppe & $1804-1876$ \\
\hline Joseph von Eichendorff & $1788-1857$ \\
\hline
\end{tabular}

One of the strongest influences on Brahms's songs, especially his early songs was his adaptation of folk songs. Brahms was attracted to folk song throughout his life. This interest was encouraged by his teacher Eduard Marxen (1806-1887). Of his solo song output, there are about thirty-five original settings of folk song texts. He arranged over 200 pre-existing folk song melodies. During the nineteenth century, the popular trends with folk art was to make it more expressive through the lens of regional traits. ${ }^{34}$ Sally Horgan explains that Brahms's songs were considered "volksthumlich," which means, "artistically idealizing the folk song style." 35 As he progressed in his career his arrangements of folk songs came to be considered both popular and actual folk songs themselves. There were often questions about the authenticity of his folksongs. Horgan points out that he was more concerned with the spirit of folk music, and he wanted to use that spirit to create his own version of folk song that was a reflection of his heritage and culture during that time. His devotion to folk song would start to wane in his later period, but he would retain many traits. They follow and grow with him as we see in his exploration of his Zigeunerlieder, where he continues to demonstrate his love of folk song through his adaptation of Hungarian folksong. Horgan explains that Brahms tried to bring the words and melodies of the Zigeunerlieder as close as he could to the original spirit of Hungarian folk songs. ${ }^{36}$ Brahms used

\footnotetext{
${ }^{34}$ On the divisions of folk and art music in the nineteenth century, see Matthew Gelbart, The Invention of 'Folk Music' and 'Art Music' (New York: Cambridge University Press, 2007).

35 Sally Horgan, "The Spirit of Folk Song in the Lieder of Johannes Brahms" n.d., 3. http://www.calstatela.edu/sites/default/files/centers/Wagner/documents/Brahms.pdf

${ }^{36}$ Horgan, "The Spirit of Folk Song," 2.
} 
the texts brought to him by Hugo Conrat, who with the help of his Hungarian nanny Fräulein Witzl translated them into German. It is believed that Brahms took on the task of setting them musically out of pleasure together with a continued fascination with gypsy music throughout his career.

\section{Message and Mood: Early and Late}

There are some significant staples to the early settings of Brahms's texts. Max Friedlaender notices that the text declamation is handled less carefully in the early songs than in the later. ${ }^{37}$ In Op. 6, no. 4, he points to Brahms's frequent repetition of the text which is not seen often in the later works. The texts of Brahms's early songs are often seen as melodramatic when compared to his late. His early songs are usually of tales of chivalrous character, love, and feeling isolated because of the absence of a lover. He would often concentrate on certain themes that would create an immediate emotional response. Though the exuberance of fantasy and romance is heard best in the music, the text of "Nachtigallen schwingen" demonstrates a little of Brahms early emotional excess. The English translation provided by Eric Sams of this text tells the story of a maiden witnessing a scene of fantasy where nightingales are singing, and flowers are blooming. In the midst of all this, she solemnly wonders where her flower could be. ${ }^{38}$

\footnotetext{
${ }^{37}$ Max Friedlaender, Brahms's Lieder: An Introduction to the Songs for One and Two Voices (New York: AMS Press, 1976), 6.

${ }^{38}$ Sams, The Songs of Johannes Brahms, 49.
} 


\section{Example 2.2 Op. 6, no. 4, "Nachtigallen schwingen" (August Heinrich Hoffmann von Fallersleben).}

Nachitgallen schwingen lustig ihr Gefieder, Nachtigallen singen ihre alten Lieder.

Und die Blumen alle, sie erwachen wieder

Bei dem Klang und Schalle aller dieser Lieder.

Und meine sehnsucht wird zur Nachtigall

Und fliegt in die blühende welt hinein, Und fragt bei den blumen überall,

Wo mag doch mein, mein Blümchen sein?

Und die Nachtigallen schwingen ihren reigen

Unter Laubeshallen zwischen blütenzweigen,

Von den blumen allen aber ich muß schweigen.

Unter ihnen steh' ich Traurig sinnend still:

Eine Blume seh ich, die nicht blühen will.

These themes of lovelorn fantasy follow Brahms throughout his career, mellowing slightly in character as maturity, hard life experiences, and thoughts of mortality bring a new character into the texts of his late songs.

As Malcom MacDonald argues, Brahms suffered a significant amount of loss in the last 20 years of his life. ${ }^{39}$ His friends Tausig and Feuerbach died in 1877 and 1880 . He was able to be at his friend Nottebohms's bedside when he passed in1882, and Grädener followed in 1883. His past teacher Marxsen and his friend Richard Pohl both died in 1887. He was later deeply grieved when he lost Lisl von Herzogenberg in 1892 who died at the age of forty-four. Later that same year he would lose his sister and become the last of his blood relatives still living. He would go on to lose several more of his close friends in the following years leading up until his death in 1897. In the midst of all this grief, in addition to his own possible contemplations of mortality as he grew older, we find more texts selected by Brahms that seem to circulate around death or a loss of youth or time.

\footnotetext{
${ }^{39}$ MacDonald, Brahms, 295-296.
} 
With this in mind, it is important to observe that not all of his songs share a dark and contemplative mood. MacDonald explains that from Opp. 94-97 Brahms goes back and forth between darker and more positive moods. In Opp. 94 and 96, one hears grimmer and ambiguous songs. However, in Opp. 95 and 97 one encounters lighter songs. Since all the songs within each set were not necessarily composed during the same year, it is a little harder to pinpoint why these shifts occurred. For example, the songs in Op. 94 are documented as being composed either in 1883 or 1884 . What we do know is that they were composed during a time in Brahms's life when he was dealing with losing many loved ones amid his own thoughts of mortality.

\section{Example 2.3 Opus 94. No. 1, “Mit vierzig Jahren” ( Freiedrich Rückert).}

Mit vierzig Jahrenist der Berg erstiegen, Wir stehen still und schaun zurück; Dort sehen wir der Kindheit stilles liegen Und dort der Jugend lautes Glück.

Noch einmal schau', und dann gekräftigt weiter Ergebe Deinen Wanderstab! Hidehnt ein Bergesrücken sich ein breiter Und hier nicht, drübe gehts hinab.

Nicht athemend aufwärts brauchst du mehr zu steigen, Die Eben zieht von selbst dich fort; Dann wird sie sich mit dir unmerklich neigen, Und eh du's denkst, bist du im Port.

The first song in Op. 94, "Mit vierzig Jahren," gives us one of the first clear examples of Brahms tapping into a reminiscent spirit. The title translates to "At Forty years old," and the poem speaks from the point of view of someone who, at the age of forty, is looking back and remembering the joys of youth. ${ }^{40}$ Although this he is looking back at life and at the time that has been lost, he is also sharing his hope for the future in that the hard part of the journey is over

\footnotetext{
${ }^{40}$ Sams, The Songs of, 274.
} 
now. This is not exactly the darkest text that Brahms uses, but it gives us a peek inside his possible state of mind during the time. At the time that he composed this song Brahms would have been around fifty years old and possibly relating very much to this text.

“Mein Herz ist schwer," in Example 2.4, carries once again a theme of looking back at one's life, but there is not a hopeful ending as there was with "Mit vierzing Jahren." ${ }^{41}$ In this narration, the maiden's heart is heavy with grief over the time that she has lost and the poem ends with the wind carrying her grief through the air. We see these kinds of themes sprinkled throughout Brahms late songs. However, as stated before it is not the only theme/mood that Brahms explores.

\section{Example 2.4 Op. 94, no. 3, "Mein Herz ist schwer" (Emanuel Geibel).}

Mein Herz ist schwer, mein Augu wacht, Der wind fährt seufzend durch die nacht; Die wipfel rauschen weit und breit, Sie rauschen von vergagner zeit.

Sie rauschen von vergagner zeit, Von großen Glück und herzeleid Vom schloß und von der Jungfrau drinWo is das alles, alles hin?

Wo is das alles, alles hin, Leid, Lieb' und Lust und Jugendsinn? Der wind fährt seufzend durch die nacht, Mein herz ist schwer, mein auge wacht.

In Example 2.5, we see Brahms calling on a familiar theme in "Der Jäger" (Op. 95), one that he also used in his youth. In a folk song performance, this song presents a bright and sunny mood much different from the previous two texts. In this poem the maiden sings of her lover who is a huntsman and describes what a great huntsman he is.

\footnotetext{
${ }^{41}$ Sams, The Songs of, 277.
} 


\section{Example 2.5 Op. 95, no. 4, "Der Jäger" (Friedrich Halm).}

Mein Lieb ist ein Jäger, und grün ist sein kleid,

Und blau ist sein auge, nur sein herz ist zu weit.

Mein lieb ist ein Jäger, trifft immer ins ziel, Und mädchen berückt er, so viel er nur will.

Mein Lieb ist ein Jäger, kennt wege und spur, Zu mir aber kommt er durch die kirchtüre nur!

This may show us that even though Brahms allowed mortality to come into his creative process, he did not completely give over to it when it came to the type of songs he wanted to compose. We see the theme of mortality in text come to a peak in his final work for voice, Vier ernste Gesänge, Op. 121. In this set Brahms calls on Biblical texts found in Ecclesiastes, Ecclesiasticus, and 1 Corinthians. While Brahms was composing Vier ernste Gesänge, Clara Schumann was suffering from an illness that would eventually take her life on the 20 May 1896. Although the creation of Vier ernste Gesänge and the death of Clara Schumann fell in the same year, it is not believed that she was Brahms's primary inspiration for the work. Some scholars, including Lucian Stark, suggest that it could have been the inevitability of her death mixed with his already somber mood brought on by the recent deaths in his life.

There is a letter, dated 8 May 1896, written by Brahms to his friend Fritz Simrock, stating that he intended them to be for someone else. ${ }^{42}$ In this letter, Brahms announces that he is finishing the songs that will become the Vier ernste Gesänge and that he intends to dedicate them to Max Klinger. The letter from Brahms speaks volumes about his emotional state alone. He speaks of writing a "few small songs," which is documented as being the Four Serious Songs,

\footnotetext{
42 Johannes Brahms and Styra. Avins, Johannes Brahms: Life and Letters (Oxford ; Oxford University Press, 1997), 733.
} 
Op. 121. What is interesting about this exchange is that there seems to be no sorrow shadowing them. There are actually some humorous jabs made at their existence and the possible effects they could have on the public. It is almost as if Brahms is taking the thoughts of mortality and recent losses in his life all in his stride, not in a way that would suggest that he does not care, but rather in a way that suggests that he has made peace with its inevitability. Other scholars, such as Martin Meiser, believe Brahms's outlook on the subject was a bit bleaker that this letter would suggest. ${ }^{43}$

Daniel Beller-McKenna explains some of the views behind Brahms's use of such dark biblical text, pointing to Martin Meiser's account that had the Requiem of 1868 been written at the end of Brahms's life, the text Brahms would have chosen would have been much darker along the lines of those used in the Four Serious Songs. ${ }^{44}$ Meiser believed that one had to account for Brahms acquiring a bit more skepticism towards the hopeful views of death that are present in the German Requiem. ${ }^{45}$ This assessment of course completely disregards the message of the fourth and last song which is completely different from the first three. Although the fourth song is recorded as being composed a year before, there has to be a reason why Brahms felt that it belonged with the set. Many have felt that Brahms setting of op.121 was connected to the philosophical trend of the age cultivated by Schopenhauer. By the 1880s, the middle-class liberalism was under attack in Vienna by the anti-liberal movements of the 1880 s and 1890 s. There was a new intellectual branch that fueled this endeavor that embraced the philosophy and ideas of Schopenhauer, Nietzsche, and Wagner. In Schopenhauer's philosophy of the Will, he eliminates the spiritual aspect of our existence, arguing that there is no God guiding us all with

\footnotetext{
${ }^{43}$ For a detailed account of Martin Meiser's point of view see, Beller-MacKenna, "Brahms, the Bible," ch 5.

${ }^{44}$ Beller-MacKenna, "Brahms, the Bible,"182.

45 Beller-MacKenna, "Brahms and the Bible," 182.
} 
his divine plan. Looking at the texts of Op. 121, we can see the parallel between this philosophy

and the message of the Ecclesiastes texts.

\section{Example 2.6 Vier ernste Gesänge, no. 1, "Denn es gehet" (Ecclesiastes 3:19-22).}

\begin{abstract}
19.Denn es gehet dem Menschen wie dem Vieh, wie dies stirbt, so stirbt er auch; und haben alle einerlei Odem; und der Mensch hat nichts mehr den das Vieh; den es ist alles eitel.
\end{abstract}

20.Es fährt alles an einen Ort; es ist alles von Staub gemacht, und wird wieder zu Staub.

21.Wer weiß, ob der Geist des Menschen aufwärts fahre, und der Odem des Viehes unterwärts unter die Erde fahre?

22.Darum sahe ich, daß nichts besser's ist, den daß der Mensch frölich sei in seiner Arbeit; den das ist sein Teil. Denn wer will ihn dahin bringen, daß er sehe, was nach ihm geschehen wird?
19.For that which happens to the sons of men happens to animals. Even one thing happens to them. As the one dies, so the other dies. Yes, they have all one breath; and man has no advantage over the animals; for all is vanity.

20.All go to one place. All are from the dust, and all turn to dust again.

21. Who knows the spirit of man, whether it goes upward, and the spirit of the animal, whether it goes downward to the earth?

22. Therefore I saw that there is nothing better than that a man should rejoice in his works; for that is his portion: for who can bring him to see what will be after him ? $^{46}$

\section{Example 2.7 Vier ernste Gesänge, no. 2, "Ich wandte mich," (Ecclesiastes 4:1-3).}

1.Ich wandte mich und sahe an alle, die Unrecht leiden unter der Sonne; und sehe, da waren Tränen derer, die Unrecht litten und hatten keinen Tröster, und die ihnen Unrech täten, waren zu mächtig, daß sie keinen Tröster haben konnten.

2.Da lobte ich die Toten, die schon gestorben waren, mehr also die Lebendigen, die noch das Leben Hatten;

3.Und der noch nicht ist, ist besser also alle beide, und des Bösen nicht inne wird, das unter der Sonne geschieht.
1.Then I returned and saw all the oppression that are done under the sun: and behold, the tears of those who were oppressed, and they had no comforter; and on the side of their oppressors there was power; but they had no comforter.

2.Therefore I praised the dead who have been long dead more than the living who are yet alive.

3.Yes, better than them both is him who has not yet been, who has not seen the evil work that is done under the sun. ${ }^{47}$

\footnotetext{
${ }^{46}$ Michael Paul Johnson, "World English Bible with Deuterocanon,” https://ebible.org/web/.

47 Johnson, "World English Bible with Deuterocanon".
} 
Example 2.8 Vier ernste Gesänge, no. 3, "O Tod, wie bitter bist du" (Ecclesiasticus 41:1-2).

1.O Tod, wie bitter bist du, wenn an dich gedenket ein Mensch, der gute Tage und genug hat und ohne Sorge lebet; und dem es wohl geht in allen Dingen und noch wohl essen mag!

2.O Tod, wie wohl tust du dem Dürftigen, der da schwach und alt ist, der in allen Sorgen steckt, und nichts Besser's zu hoffen, noch zu erwarten hat!
1. O death, how bitter is the remembrance of you to a man that is at peace in his possessions, to the man that has nothing to distract him, and has prosperity in all things, and that still has strength to receive meat!

2.O death, acceptable is your sentence to a man that is needy, and that fails in strength, that is in extreme old age, and is distracted about all things, and is perverse, and has lost patience! ${ }^{48}$

Example 2.9 Vier ernste Gesänge, no. 4, "Wenn ich mit Menschen" (1 Corinthians 13:13,12-13).

1.Wenn ich mit Menschen-und mit Engelzungen redete, und Hätte der Liebe nicht, so wär ich ein tönend Erz, oder eine klingende Schelle.

2.Und wenn ich weissagen könnte und wüßte alle Geheimnisse und alle Erkenntnis, und hätte allen Glauben, also, daß ich Berge versetzte; und hätte der Liebe nicht, so wäre ich nichts.

3.und wenn ich alle meine Habe den Armen gäbe, und ließe meinen Leib Brennen; und hätte der Liebe nicht, so wäre mir's nichts nütze.

12. Wir sehen jetzt durch einen Spiegel in einem dunkeln Worte, dann aber von Angesicht zu Angesichte. Jetzt erkenne ich's stückweise, dann aber werd' ich's erkennen, gleichwie ich erkennet bin.

13.Nun aber bleibet Glaube, Hoffnung, Liebe, diese drei; aber die Liee ist die größeste unter ihnen.
1.If I speak with the languages of men and of angels, but don't have love, I have become sounding brass, or a clanging cymbal.

2.If I have the gift of prophecy and know all mysteries and all knowledge; and if I have all faith, so as to remove mountains, but don't have love, I am nothing.

3.If I give away all my goods to feed the poor, and if I give my body to be burned, but don't have love, it profits me nothing.

12.For now we see in a mirror, dimly, but then face to face. Now I know in part, but then I will know fully, even as I was also fully known.

13.But now faith, hope, and love remain - these three. The greatest of these is love. ${ }^{49}$

The excerpts selected by Brahms from Ecclesiasticus certainly seem to be devoid of God's presence in the midst of darkness and negativity. Beller-McKenna explains that the parallels are definitely evident if you think about the message that Schopenhauer frequently reminded his readers of which was "nothingness is preferable to life, which is full of misery." 50

\footnotetext{
48 Johnson, "World English Bible with Deuterocanon".

49 Johnson, "World English Bible with Deuterocanon".

${ }^{50}$ Beller-McKenna, "Brahms, the Bible," 187.
} 
McKenna's study demonstrates there is strong evidence that Brahms was very knowledgeable in Schopenhauer's idea, having read a lot of Schopenhauer's writings and maintaining an interest in them later in his life. Furthermore, he gives the strongest evidence in an account by Joseph Suk of a conversation that he had with Brahms, Dvorak, and Dvorak's wife Anna. During this conversation Suk recounts hearing Brahms talk about how his reading of Schopenhauer may have affected his views towards faith. Suk expressed that hearing Brahms speak this way made it seem as if Brahms believed in nothing. ${ }^{51}$

This conversation seems to be strong evidence that Brahms's outlook had almost been tainted by the philosophy of Schopenhauer. However, according to Beller-Mckenna, this evidence still does not account for the spiritual side of Brahms that still remained throughout his life. Although it seems that Brahms was not an overly religious man, he did maintain a sense of spirituality. Later remarks made by Brahms provide more evidence against the idea that Brahms succumbed completely to Schopenhauer's pessimism. In fact, Eduard Hanslick once wrote about a moment when Brahms shared his disgust about all the new music critics who quoted Schopenhauer and Nietzsche..$^{52}$

Op. 121 seems not to be a product of Schopenhauer pessimism, but rather a product of Brahms finding his way through it and still coming out on the other side with hope. One of the most debated topics about Vier ernste Gesänge is that the last song does not belong in the set. The text and the music are completely different from the first three. There may have however been a deliberateness to this contrast. The first three songs present thoughts of death and despair with no consolation on the horizon. It falls very much into the realm of a pessimistic person devoid of positivity, hope, joy, or compassion. Then the fourth song completely flips the mood

\footnotetext{
${ }^{51}$ Beller-McKenna, "Brahms, and the Bible," 191.
}

${ }^{52}$ Beller-McKenna, "Brahms, and the Bible," 192. 
of the set. If you look at the text of the fourth song from 1 Corinthians, you see that the overall point of the text is love. Paul reminds the church at Corinth that if you have power, wealth, gifts, knowledge, etc., but not love, you have nothing. If we did not know all that had previously been presented in this chapter, we would find the placement of this text very odd. However, now that we do know the climate that Brahms composed this work, it puts our understanding of them all under a different light. What if we looked at the work not as a result of Schopenhauer pessimism, but as a response to it? It would be an exact mirror of how Brahms looked at death later in life. The set altogether says yes death is inevitable, and makes life seem meaningless, but what good is living a life without love. In other words, what good is living out the rest of your life as a pessimist or without any hope. If we look back at what we've discovered about Brahms's last songs the view is solidified. He embraced thoughts of death in some of his later song text, but he did not dwell in them and allow them to take him into darkness. Which is why we see him bringing back lighter folk songs with tales of love and honor. In August of 1894, Brahms wrote to Clara Schumann about the Volkslieder. In his correspondence with Schumann, he asks her if she noticed that his last songs seem to recall his early songs. He goes on to explain how the revelation creates an image of a closed circle of his life's work. ${ }^{53}$

Once again, this points back to Brahms's nostalgia and melancholy, as well as to the possible idea that Brahms's Romantic connotations may have represented his spirituality in his music. Where before there was a line drawn between the Bible and Brahms's Romantic youth, he had now brought them together at the end of his life to combat the negative effects of pessimism that were trying to take over him as he grew closer to death.

\footnotetext{
${ }^{53}$ Beller-McKenna, "Brahms, and the Bible," 222.
} 


\section{Chapter 3}

\section{Early and Late Lieder of Brahms: Comparative Case Studies}

He was a diligent student and collector of old manuscripts, and his mastery of the musical techniques and forms of the past allowed him to superimpose his own unique style of them. ${ }^{54}$

As it has been revealed in previous chapters, many scholars have not seen much of a change between the early and late songs of Brahms. We see in chapter 2 that there definitely was an interesting change when it came to the narrative, mood, or overall effect of the texts used in his Lieder in later years. Now we will explore if the same can be said about the musical elements of his song compositions. For Brahms, his natural gifts were already prodigious even before he met Robert and Clara Schumann. Brahms's mastered his technique very early, the first performances featuring his works were well received. His early songs present elements that are characteristic of his mature style in both their simplest and most extreme form. In this chapter, we will explore just what scholars have to say about the differences (or lack thereof) between Brahms's early and late songs and take a look at some of the examples that they reference. Through their examples and others, we will examine whether any significant changes took place between his early and late songs and what they might have been.

\section{Melody}

Robert Schumann's musical influence, together with Brahms's fascination with folk song, played a heavy role in the development of Brahms's early song melodies. He aimed to make them simple and fluently melodious. Stark also believed that folk songs aided Brahms in

\footnotetext{
${ }^{54}$ Kimball, Song: A Guide to Art Song, 103.
} 
his early songs. ${ }^{55}$ They offered him the simplest structures and opportunities for melodic inventions around text, through exploring different images of romantic poetry. Although some of his earliest songs like "Liebestreu" (Op. 6, no. 1, 1853) and "Treue Liebe” (Op. 7, no. 1, 1851) showed the potential of his creative power, Freidlaender does notice at moments in his early development where his lack of experience shines through. ${ }^{56}$ In "Juchhe" (1852), he observes that the melody is continuously interrupted and there are frequent repetitions of the text. If you look in Example 1, you can see the first page of "Juchhe". There is a noticeable difference in phrase structure when we take into consideration his other early songs. The phrases seem more linear than we're used to seeing and interrupted. Friedlaender believes this a moment in his early works where Brahms has not yet solidified the lyrical talent that he achieves since these traits are not seen in his later songs.

55 Stark, "A Guide to the Solo Songs," 2.

${ }^{56}$ Friedlaender, Brahms's Lieder, 9. 
Example 3.1 Op. 6, no. 4, “Juchhe," mm. 1-10. ${ }^{57}$

\section{J U C H HE !}

Vum K. Brimin h.
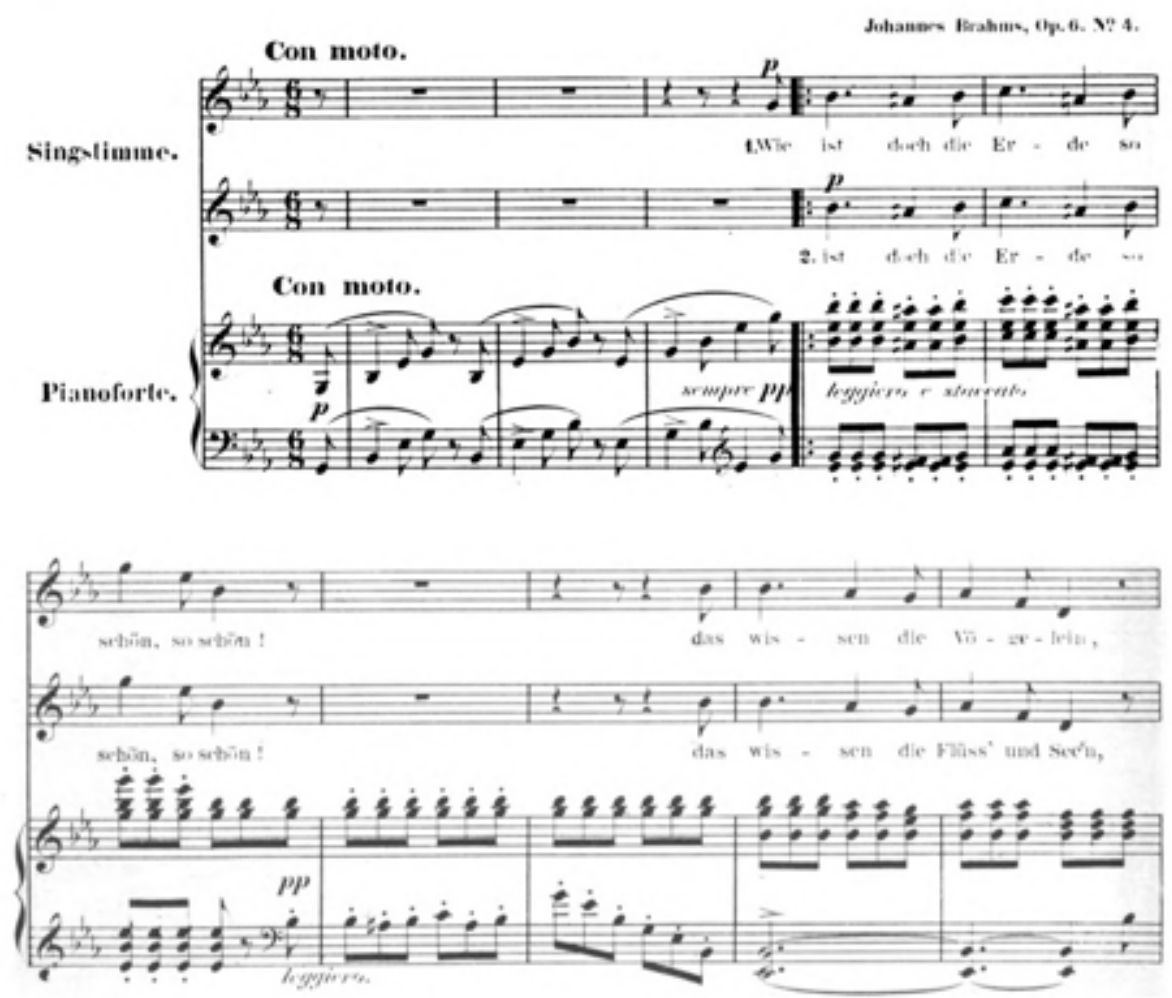

si, 84

Lucien Stark believes that the choppiness and irregularities in the phrases have to do with the poem itself and how Brahms sets it. ${ }^{58}$ Stark observes that one of the issues with the song is that it does not fit easily into the strophic mold that Brahms employed. ${ }^{59}$ Reinick's poem creates an alternation between iambic and anapestic metrical feet (an iamb is unstressed-stressed; an anapest is unstressed-unstressed-stressed). Brahms accommodates this by using single eighth note upbeats which seems to work for most of the song. However, Stark notes several inconsistencies throughout the song, including how Brahms has to remove a syllable from the

\footnotetext{
${ }^{57}$ Johannes Brahms, Sechs Gesänge für eine Sopran- oder Tenor-Stimme mit Begleitung des Pianoforte: Op. 6. (Leipzig: B. Senff, 1853), 12.

58 Stark, A Guide to the Solo Songs. 25-26.

${ }^{59}$ Stark, A Guide to the Solo Songs. 25-26.
} 
line in the last stanza to avoid the anapestic anacrusis. ${ }^{60}$ Stark goes on to say that the disorganization of this setting could be a result of Brahms being unprepared when it comes to musical consideration. ${ }^{61}$ Another reason for Brahms's melodic writing could be a result of Brahms wanting the singer to project or mirror the excitement of the poem. However, if you look at "Nachtigallen schwingen" which has a similar theme in the poetry, but does not share the melodic interruption and choppiness, it is harder to see that as a possible reason.

Most scholars acknowledge that the melody carries the expression, character, and narration. Following the German folk song tradition, the melodies were simple, and diatonic. Although his early melodies are highly expressive with bold chromaticism implemented at times for expression, the melodic development is seen as more advanced in his later songs. Scholars also observe that his early melodies carry the most melodramatic display noting how he didn't waste anytime immersing you into the drama.

In Example 3.2a, "Liebestreu," and Example 3.2b, "Nachtigallen Schwigen," he immediately presents the drama of the song instead of taking his time to slowly build up the excitement.

\footnotetext{
${ }^{60}$ Stark, A Guide to the Solo Songs, 26.
}

${ }^{61}$ Stark, A Guide to the Solo Songs, 26. 
Example 3.2a. Op. 3, no. 1, "Liebestreu," mm 1-4. ${ }^{62}$

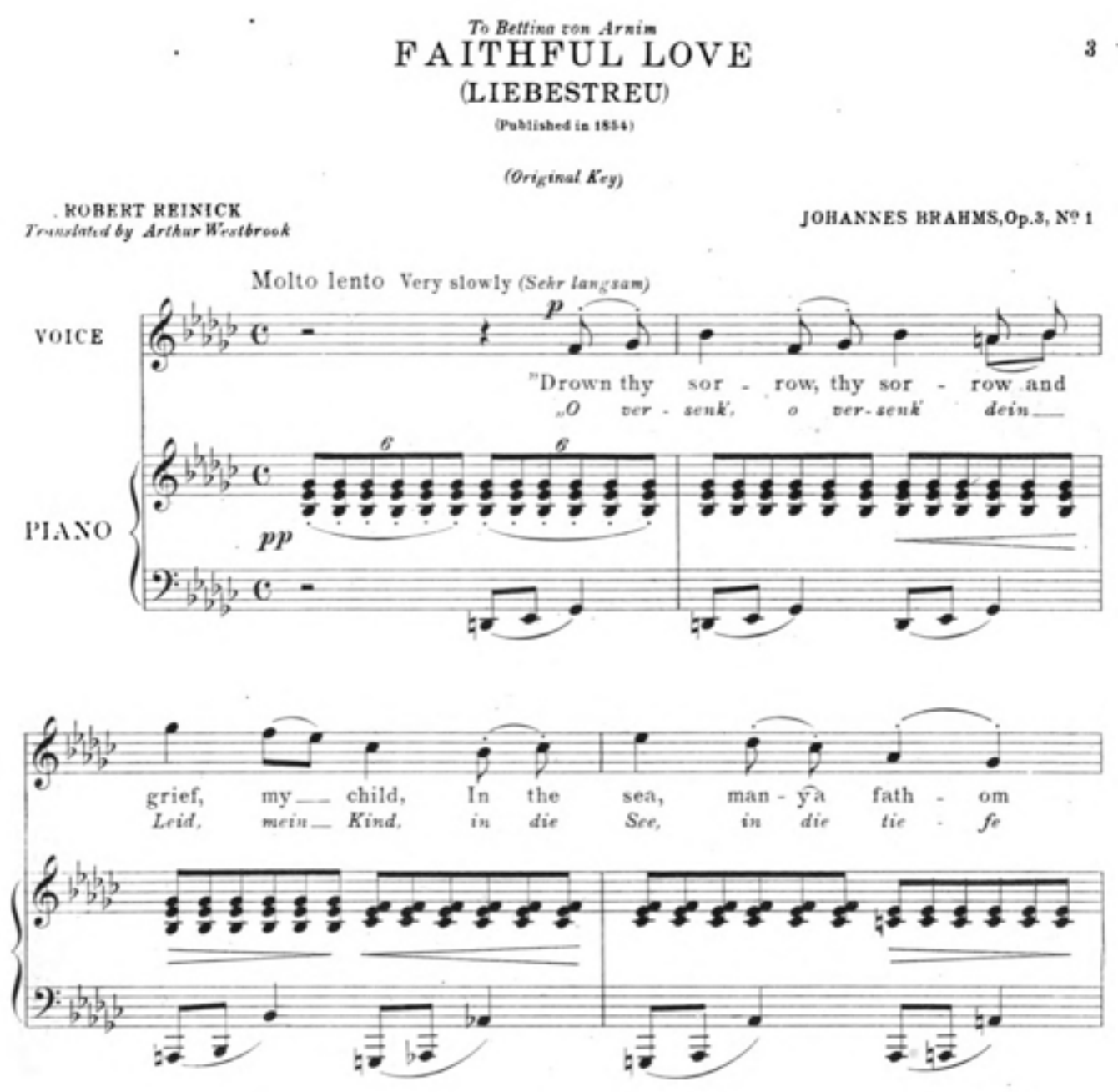

In the first few measures of "Liebesteu," you immediately hear the drama of the mother singing to her daughter. In "Nachtigallen schwingen," the singer immediately opens the songs with a broad arching melody accompanied by the piano’s joyous birdsong. In both of these examples the highest notes and most exciting moments of the melody are achieved in the first few measures.

${ }^{62}$ Johannes Brahms, Forty Songs, ed. James Huneker (New York: Oliver Ditson Company, 1903), 3. 
Example 3.2b. Op. 6, no. 6, “Nachtigallen schwingen," mm. 1-11.63

\section{"NACHTICALLEN SCHWINGEN"}

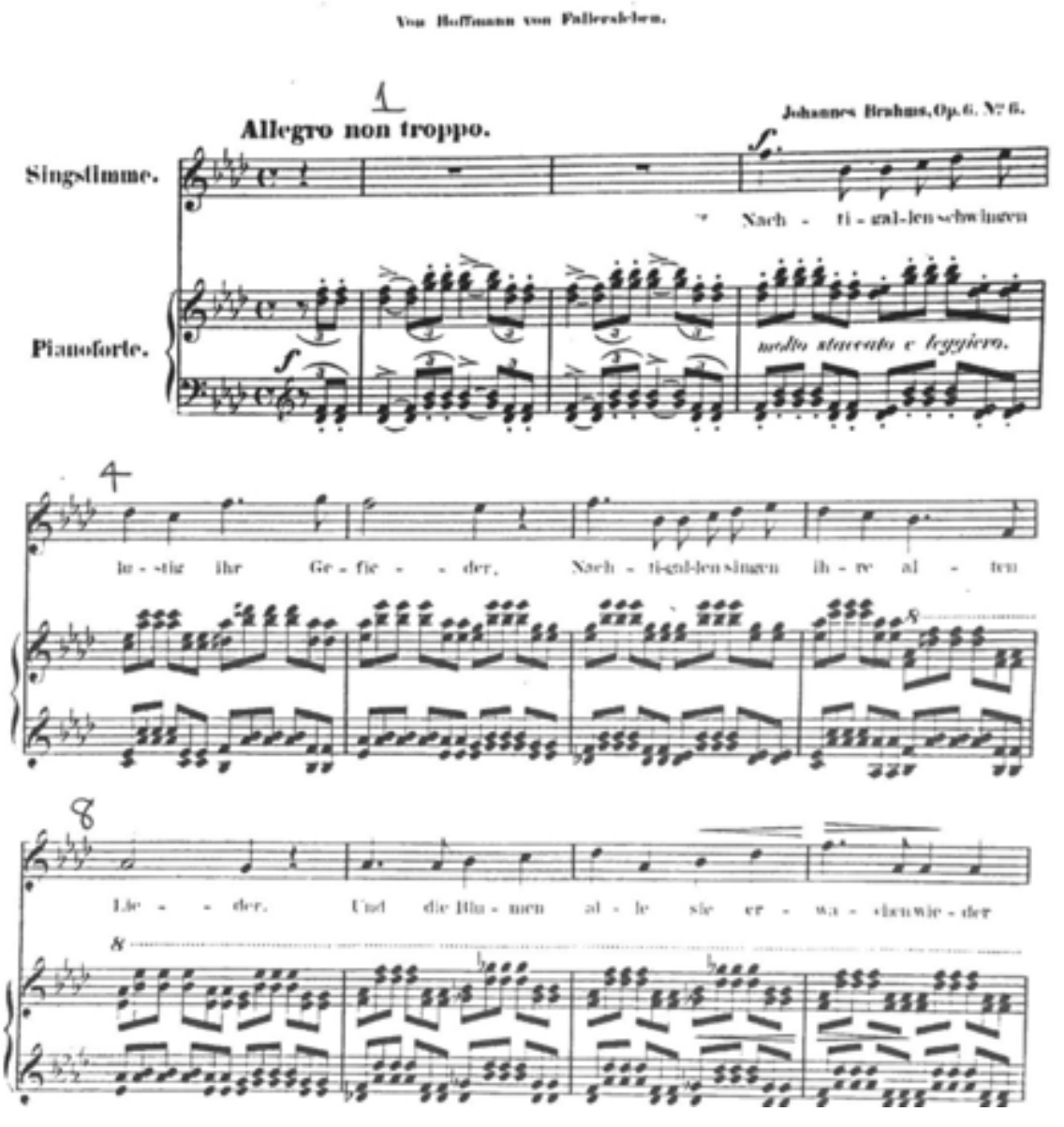

If we look at "Denn es gehet", in Example 3.3a, which is the first song from Vier ernste

Gesänge, we see some of these features carried over, however Brahms takes his time to develop the most dramatic moments in the songs.

The opening of "Denn es gehet" is already less melodramatic with its slow and brooding melody. Once again, you get a sense of the building drama in the first few measures and the highest note of the song is presented in measure 8, but Brahms withholds the more exciting

\footnotetext{
${ }^{63}$ Brahms, Sechs Gesänge, 20.
} 
moments of the song until later. Where in "Liebestreu" and "Nachtigallen schwingen," you are immediately presented with the most exciting melodic material, Brahms continues to develop the melodic excitement in "Denn es gehet" by presenting new melodies. In Example 3.3b, the Allegro section of "Denn es gehet" presents a new moment of excitement in the melody in the form of a chromatic rising line. Then, in Example 3c, you have the most exciting moments in the melody starting at measure 45 .

Example 3.3a Vier ernste Gesänge, "Denn es gehet," mm. 1-9. ${ }^{64}$

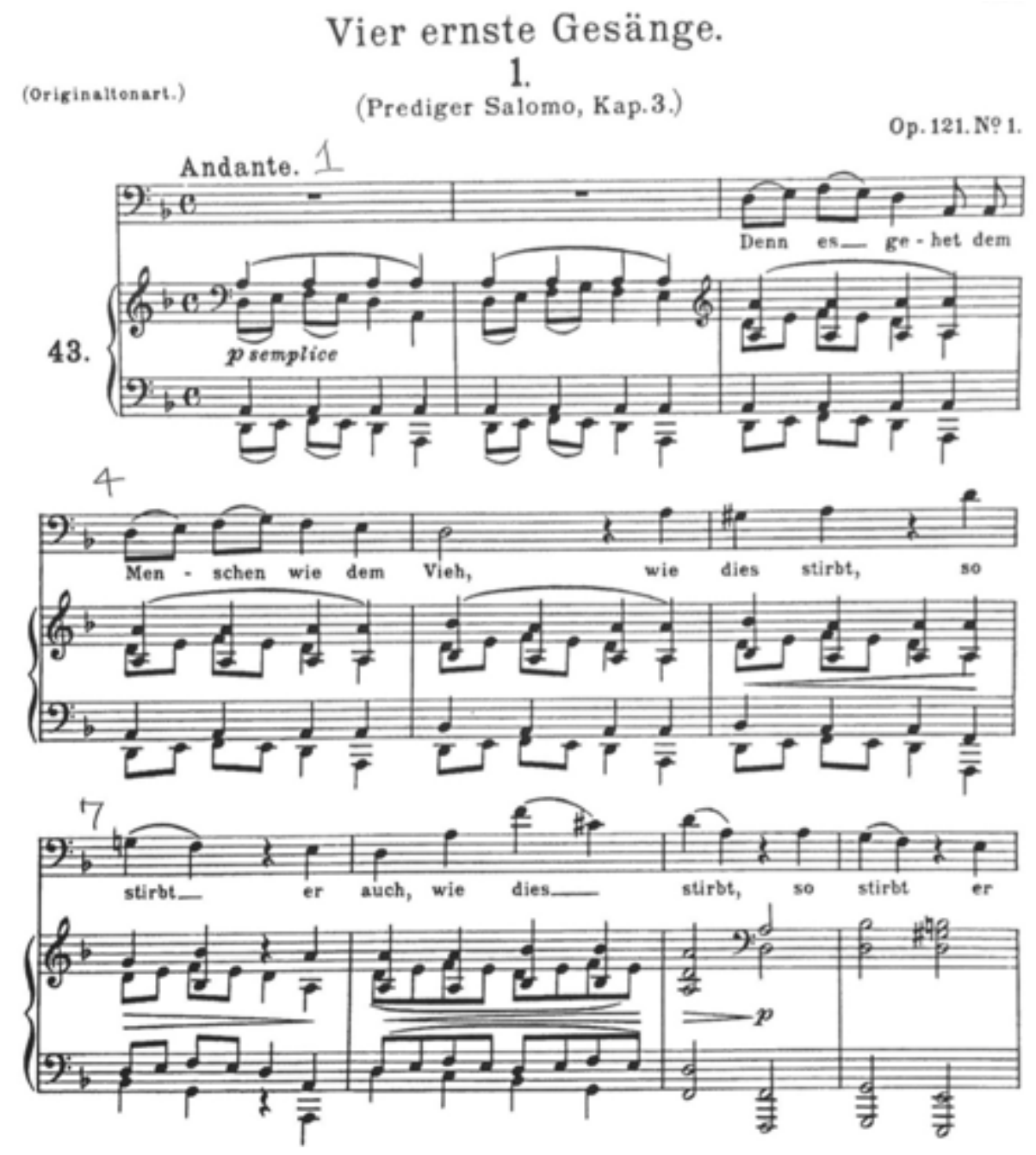

${ }^{64}$ Johannes Brahms, Vier Ernste Gesänge, ed. Max Friedlaender (Leipzig: Edition Peters, 1920), 137. 
Example 3.3b Vier ernste Gesänge, "Denn es gehet," mm. 30-38. ${ }^{65}$

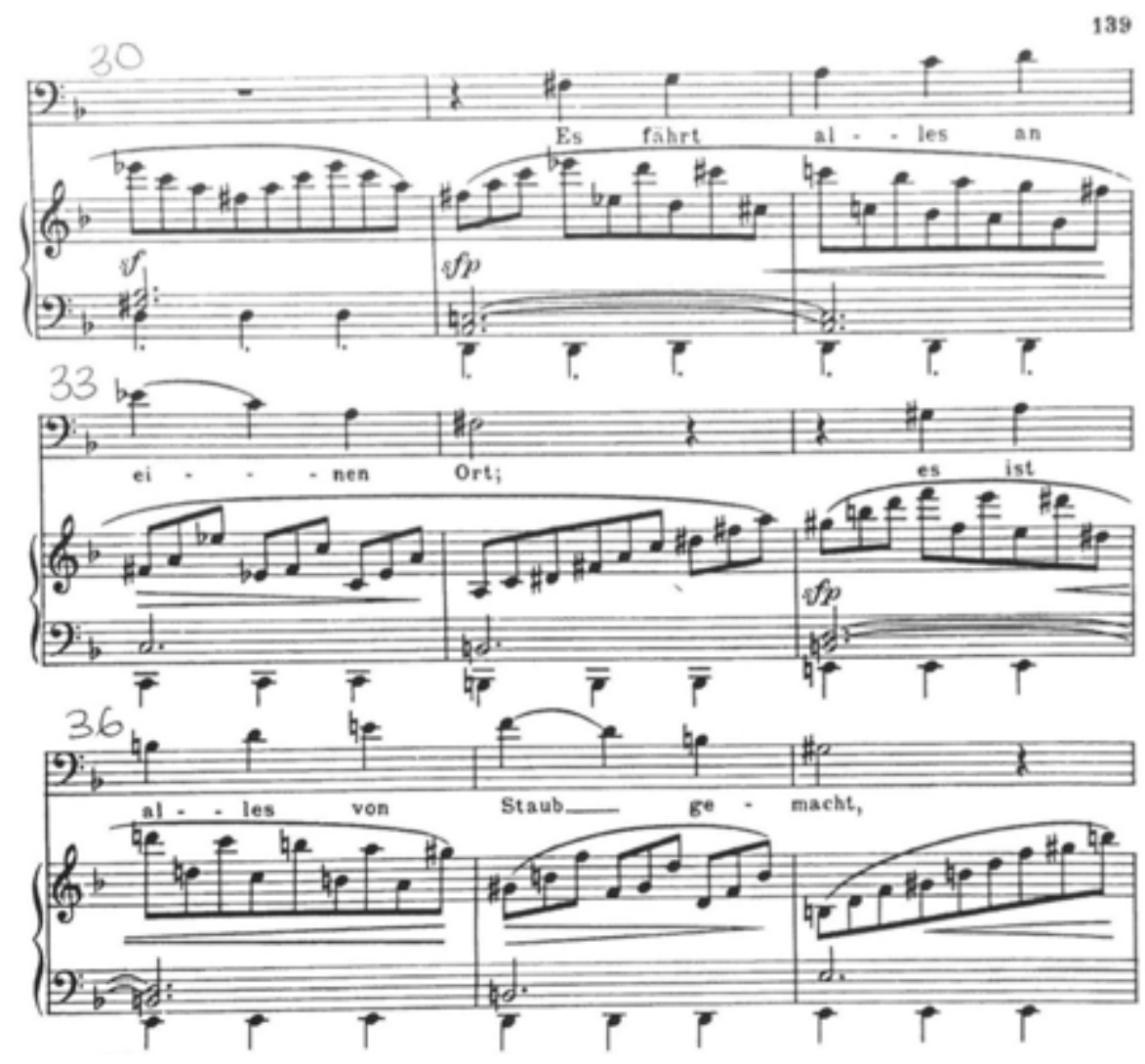

${ }^{65}$ Brahms, Vier Ernste Gesänge, 139. 
Example 3.3c Vier ernste Gesänge, "Denn es gehet," mm. 45-54. ${ }^{66}$

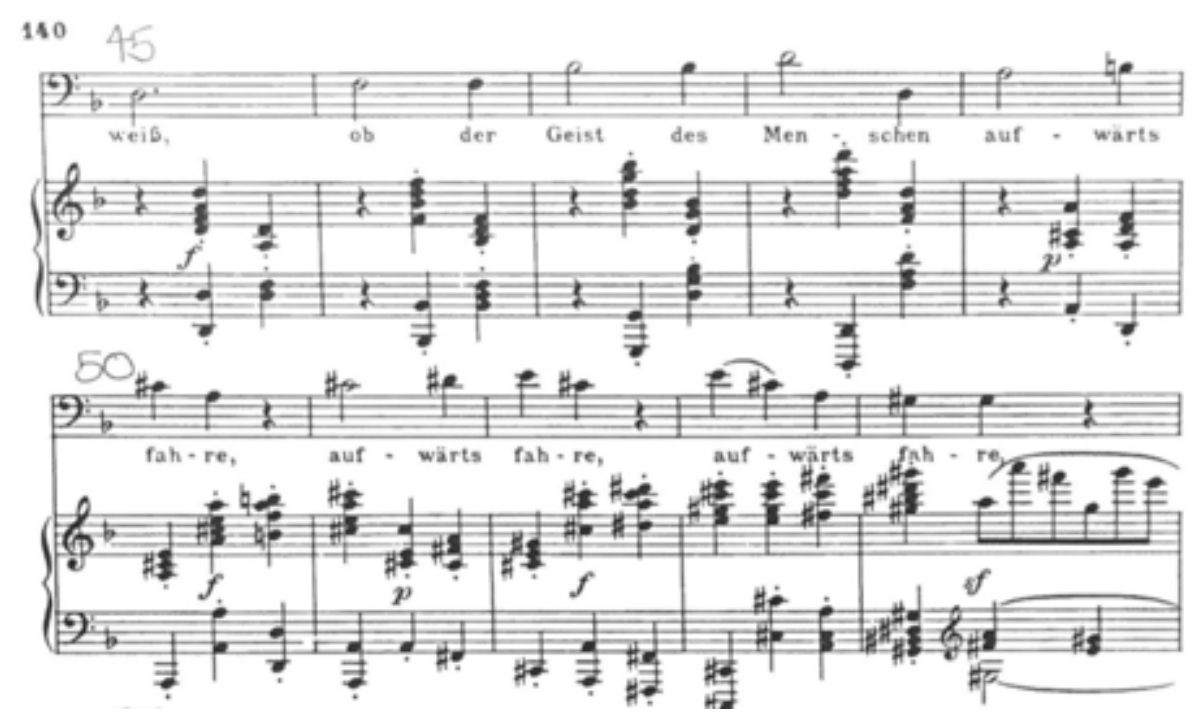

\section{Harmony and Accompaniment}

There has not been a lot of significant findings when it comes to changes in Brahms's harmonic style. Brahms's deployment of harmony is for the most part seen in the traditionally diatonic. However, he would call upon special chromatic and modal effects for expressional purposes. In his early sets, one of his greatest features is his use of harmony. He would use modal affects with chord progressions that would avoid the dominant and therefore the leading tone. He would also use prolongation to create a faraway effect often in the form of widening the tonality and give significance to secondary harmonies as tonal centers. In her dissertation on Brahm's Vier ernste Gesänge, Sue Okuda points out some of the features in his harmony that are true both to his early songs and his late songs, and points out that his harmonic use seems to be built on his traditional harmonic procedures, using chromaticism for color and expression. ${ }^{67}$ As shown in Example 4, he clearly establishes the tonal centers of each the four songs, however Okuda notes a possible device that he uses that could be attributed to a $19^{\text {th }}$ century trend.

\footnotetext{
${ }^{66}$ Brahms, Vier Ernste Gesänge, 140.

${ }^{67}$ Okuda, "Brahms's Late Song Style,"115.
} 
Example 3.4 Table of Key Areas of Vier ernste gesänge. ${ }^{68}$

\begin{tabular}{|l|l|l|l|l|}
\hline Title & "Denn es gehet" & "Ich wandte Mich" & "O Tod" & $\begin{array}{l}\text { "Wenn ich mit } \\
\text { Menschen" }\end{array}$ \\
\hline Key Areas & D minor & G minor/G Major & E minor/E Major & $\begin{array}{l}\text { Eb Major/B } \\
\text { Major/Eb Major }\end{array}$ \\
\hline
\end{tabular}

In her analysis she finds the relationship between "Denn es gehet" in $d$ minor and "Wenn ich mit Menschen", in Eb minor may suggest his use of the Neapolitan principle, where Eb is interpreted as bII of $d$ minor. She also points out that if you look at "O Tod" which is in E Major as its' enharmonic spelling of $\mathrm{Fb}$ Major, it too bears a Neapolitan relationship to Eb Major, which is the key of "Wenn Ich mit Menschen". ${ }^{69}$ The practice of relating songs in sets by minor seconds was widely being implemented into the harmonic development of the $19^{\text {th }}$ century.

Okuda suggest that this might be a moment in Brahms's harmonic development that was affected by nineteenth century trends.

In the 1860 s, which is what some consider Brahms's 'first maturity', you start to perceive an increase of strong harmonies. This appears to be a peak in his harmonic use if you consider Michael Musgraves' findings which reveal that his harmonic development actually became more refined and subtle in his later songs. ${ }^{70}$ His harmonies have a renaissance quality using simple chord progressing and avoiding seventh chords, and frequently calling on complex counterpoint, pedal point and augmentation. Through this refinement of his skills, Brahms developed a vast harmonic vocabulary that he tended to use in the most subtle or cerebral way. In Example 3.5, Musgraves takes two folk songs that Brahms set in 1858 and compares them to the setting that Brahms did of the same two folk songs in 1894. Musgraves provides the examples to show how

\footnotetext{
${ }^{68}$ Okuda, “Brahms's Late Song Style," 115.

${ }^{69}$ Okuda, "Brahms's Late Song Style," 115-116.

${ }^{70}$ Michael Musgrave, The Music of Brahms (Oxford: Clarendon Press, 1994).
} 
Brahms approaches the same folk songs in his later years. The changes are minimal to the eyes, but the "subtle" changes that Musgrave points out are good examples of Brahms's harmonic refinement in his later songs. Example 3.5a and 3.5b show the first few measures of "Marias Wallfahrt" from 1858 and 1894. If you compare the two, you see that harmony in the piano part has been filled out or expanded to create a richer texture. Musgrave notes that in the 1894 setting of "Marias Wallfahrt," Brahms refines his love of modal effects through contrapuntal means.

Example 3.5c and 3.5d provides the first 4 measures of "Das Mädchen und der Tod" from 1858 and 1894. In these examples, the refinement falls once again in the harmonic treatment. The harmonization of the 1894 settings use pedal and chromatic inner parts to establish a richer and more ambiguous harmony. Musgraves points out that Brahms's harmonization in the 1858 setting is clumsy in his mind. However, in the 1894 setting his harmonic treatment is refined through modal effects, use of pedal, and his use of chromatic inner parts.

\section{Example 3.5a WoO 32, no. 22, "Marias Wallfahrt" (1858), mm. 1-4.}

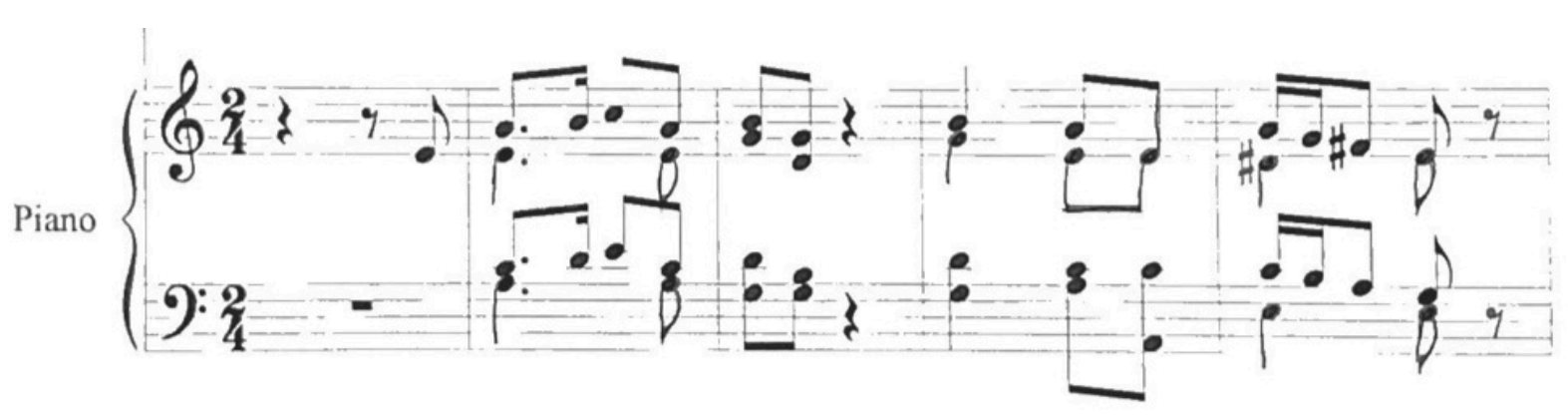


Example 3.5b "Marias Wallfahrt" (1894), mm. 1-3. ${ }^{71}$

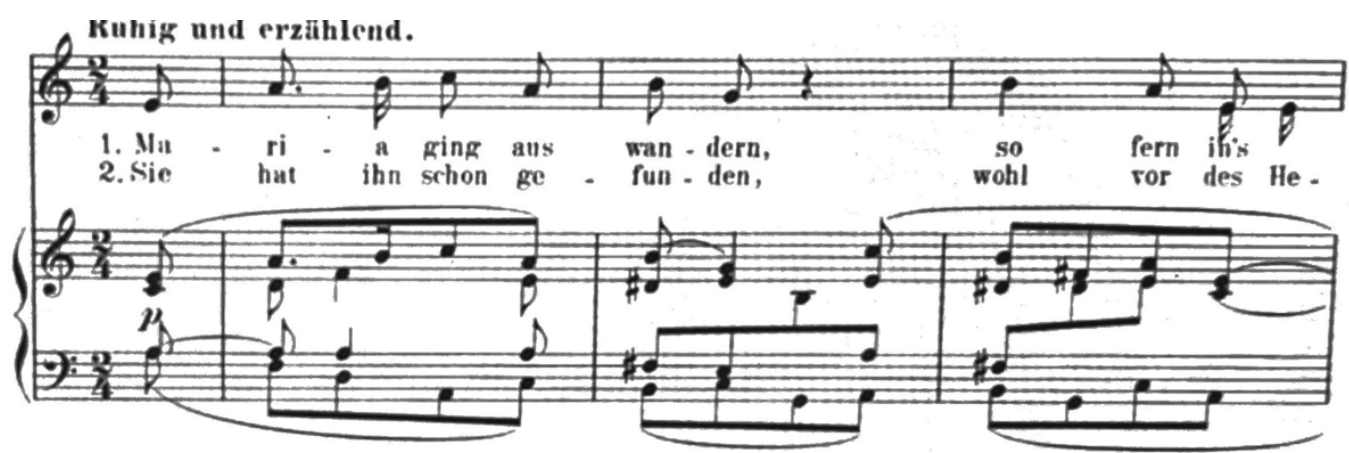

Example 3.5c WoO 32, no. 23, “Das Mädchen und der Tod” (1858), mm. 1-3.

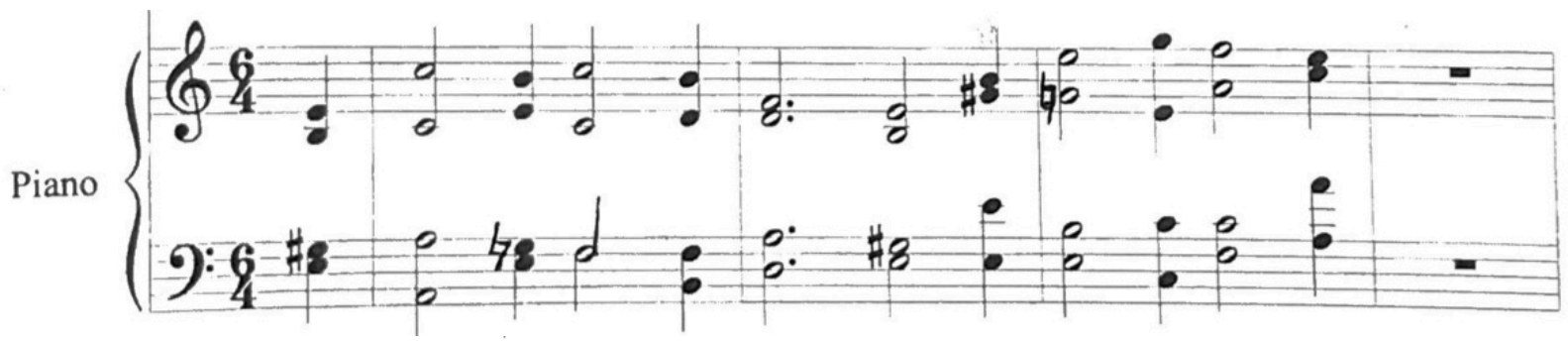

Example 3.5d "Das Mädchen und der Tod" (1894), mm. 1-3.72

Gehend und dem Gedicht angemessen erzählend.

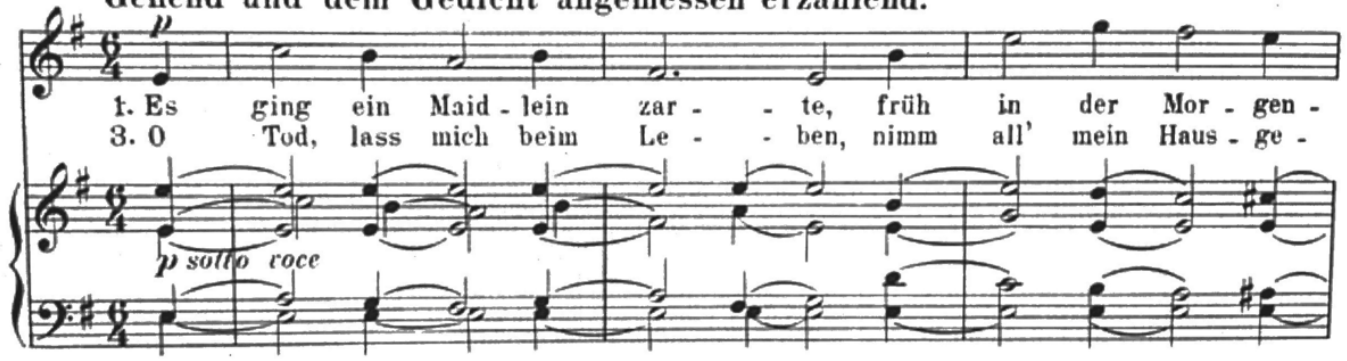

71 Johannes Brahms, 49 Deutsche Volkslieder, First Edition (Berlin: N.Simrock, 1894), 108.

72 Brahms, 49 Deutsche, 118. 
With Brahms's early songs, the piano gives only the simplest support to the melody and harmony. As with the melody, Brahms drew from the simplicity of folksongs accompaniment as well as classical models. Lucian Stark viewed his early folk song accompaniment as simple and naïve, and believed that the accompaniment in his later years grew to assume more importance and independence. ${ }^{73}$ With the melody maintaining the consistent rhythms, the accompaniment would display more complex rhythmic patterns. Though he was not overly concerned with text painting, he did use the piano to present actions and scenery in an unfolding and changing way. Another folk song influence that is seen consistently throughout his songs is the avoidance of long piano introductions and postludes. He abandons this at moments in his song writing like in his Magelone-Lieder (1861-1869) (which will be discussed in more detail in the next section), but for the most part, this feature is another that is maintained in his later songs. Examples 6a and Example $6 \mathrm{~b}$ demonstrate Brahms's use of short introductions and conclusions to Lieder.

${ }^{73}$ Stark, A Guide to the Solo Songs, 3. 
Example 3.6a Op. 95, no. 6, “Mädchenlied” (Am jüngsten Tag), mm. 1-3._ ${ }^{74}$

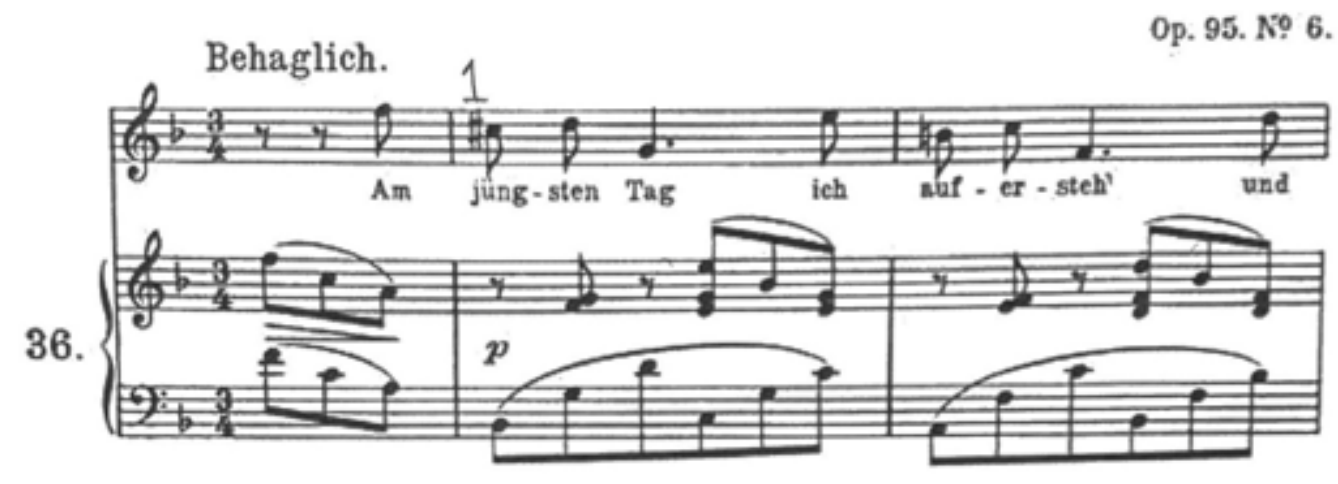

Example 3.6b Op. 95, no. 6, “Mädchenlied” (Am jüngsten Tag), mm. 27-31. ${ }^{75}$

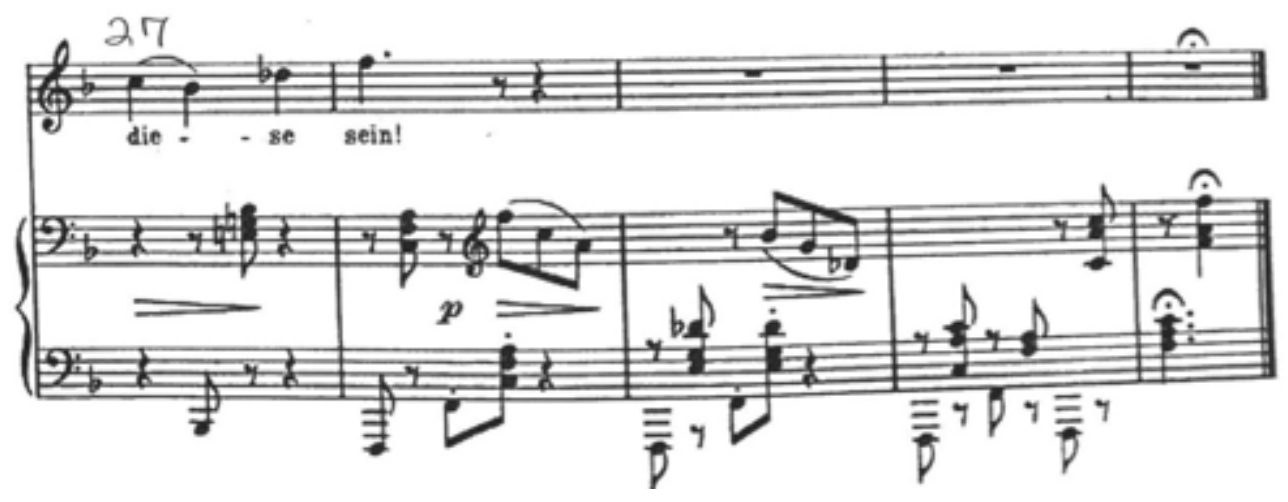

In Examples 6a, the singer has only 3 beats before they start singing in measure 1. In

Example 3.6b the song ends with 3 short and rather sparse measures in the piano. In Example

3.7a we see him implementing the same technique in "O Tod, wie bitter bist du." In this example the singer begins the song immediately on the first beat of measure 1. Once again, in Example 3.7b, Brahms finishes the song with a short postlude just one measure after the singer ends their phrase.

\footnotetext{
${ }^{74}$ Brahms, Forty Songs, 114.

${ }^{75}$ Brahms, Forty Songs, 115.
} 
Examples 3.7a Vier ernste Gesänge, "O Tod, wie bitter bist du," mm. 1-4. ${ }^{76}$

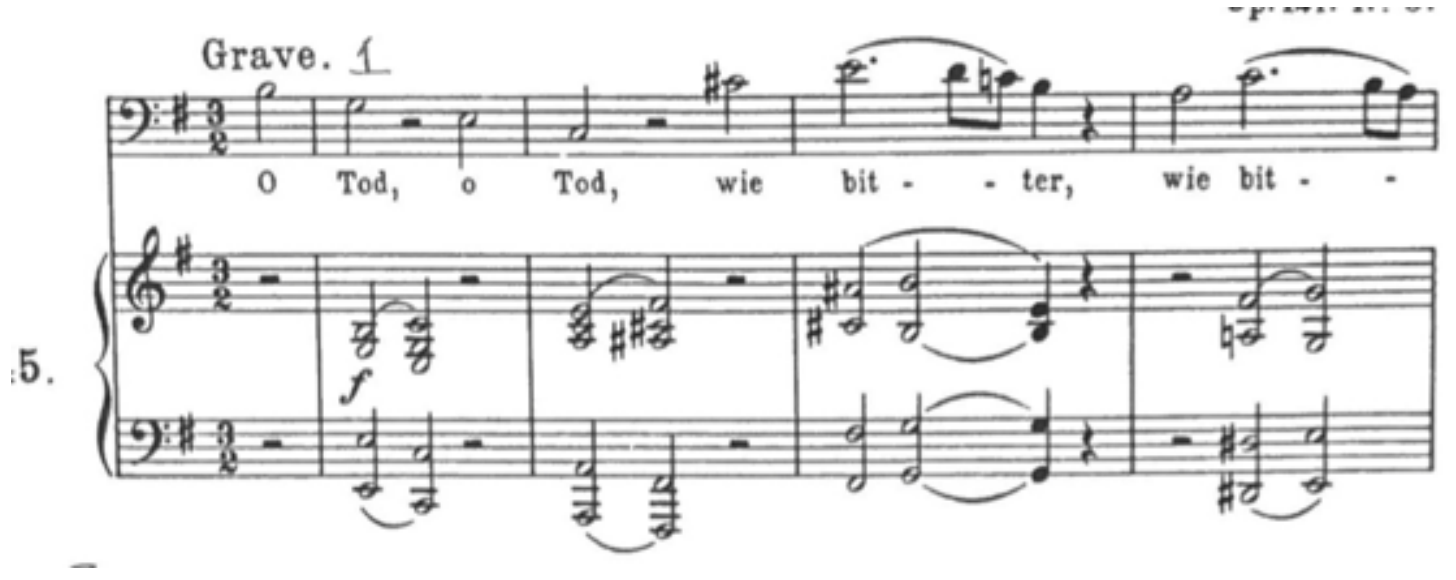

Example 3.7b Vier ernste Gesänge, "O Tod, wie bitter bist du," mm. 37-40. ${ }^{77}$

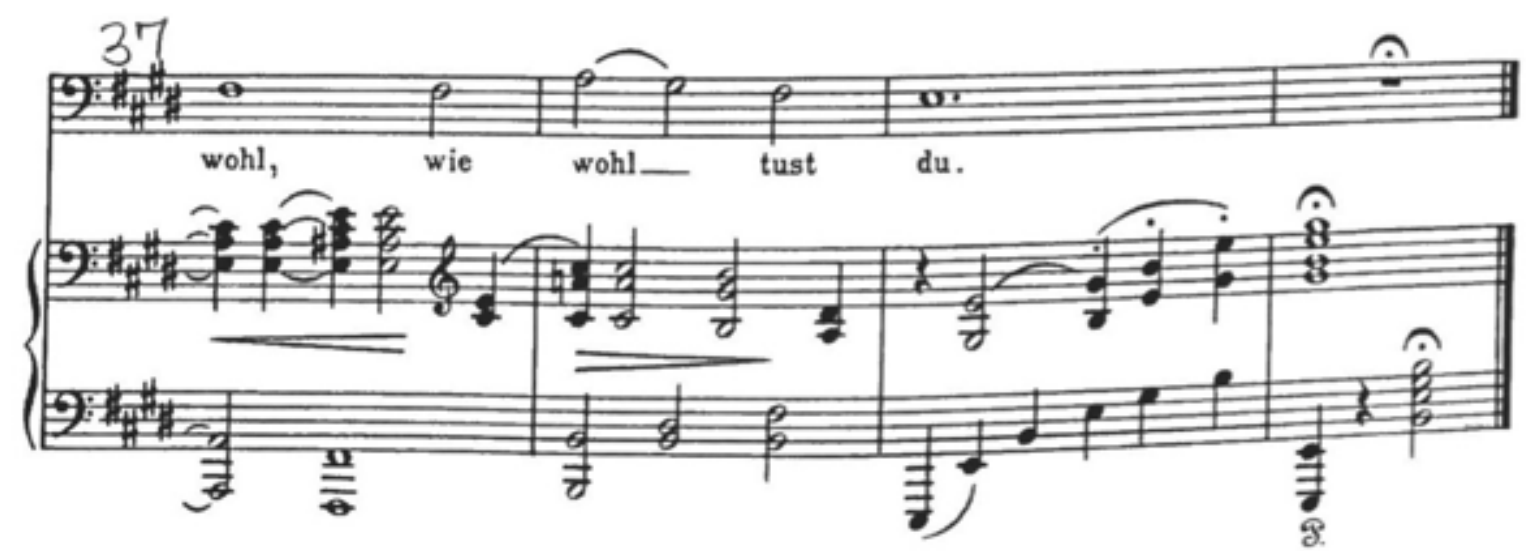

\section{Dynamics, Expression, and Form}

There is an interesting difference between Brahms's early songs and his later songs when it comes to his use of dynamics and expression. In his early publications his songs would be filled with dynamics and expression marks for the voice. Karl Geiringer observes that in the first edition of his Op. 3, the voice part was "fairly sprinkled" with expression marks. ${ }^{78}$ However, in his later years, when the same songs were published in a new edition, Brahms had cleared nearly all of the expression marks. At his maturity, his desire was to allow the singer to have the

\footnotetext{
${ }^{76}$ Brahms, Vier Ernste Gesänge, 146.

${ }^{77}$ Brahms, Vier Ernste Gesänge, 148.

${ }^{78}$ Karl Geiringer, Brahms, His Life and Work, (Garden City, New York: Doubleday, 1961).
} 
freedom to express themselves as the music lead them to do so. Each performance would have the opportunity to be different and unique and bring new beauty in this way.

In Example 3.8a, "Treue Liebe" is filled with expression marks. Brahms is in control of the singer in almost every measure and provides expression marks, or dynamics for each of them.

Example 3.8a Op. 7, no. 1, "Treue Liebe”, mm. 8-14. ${ }^{79}$
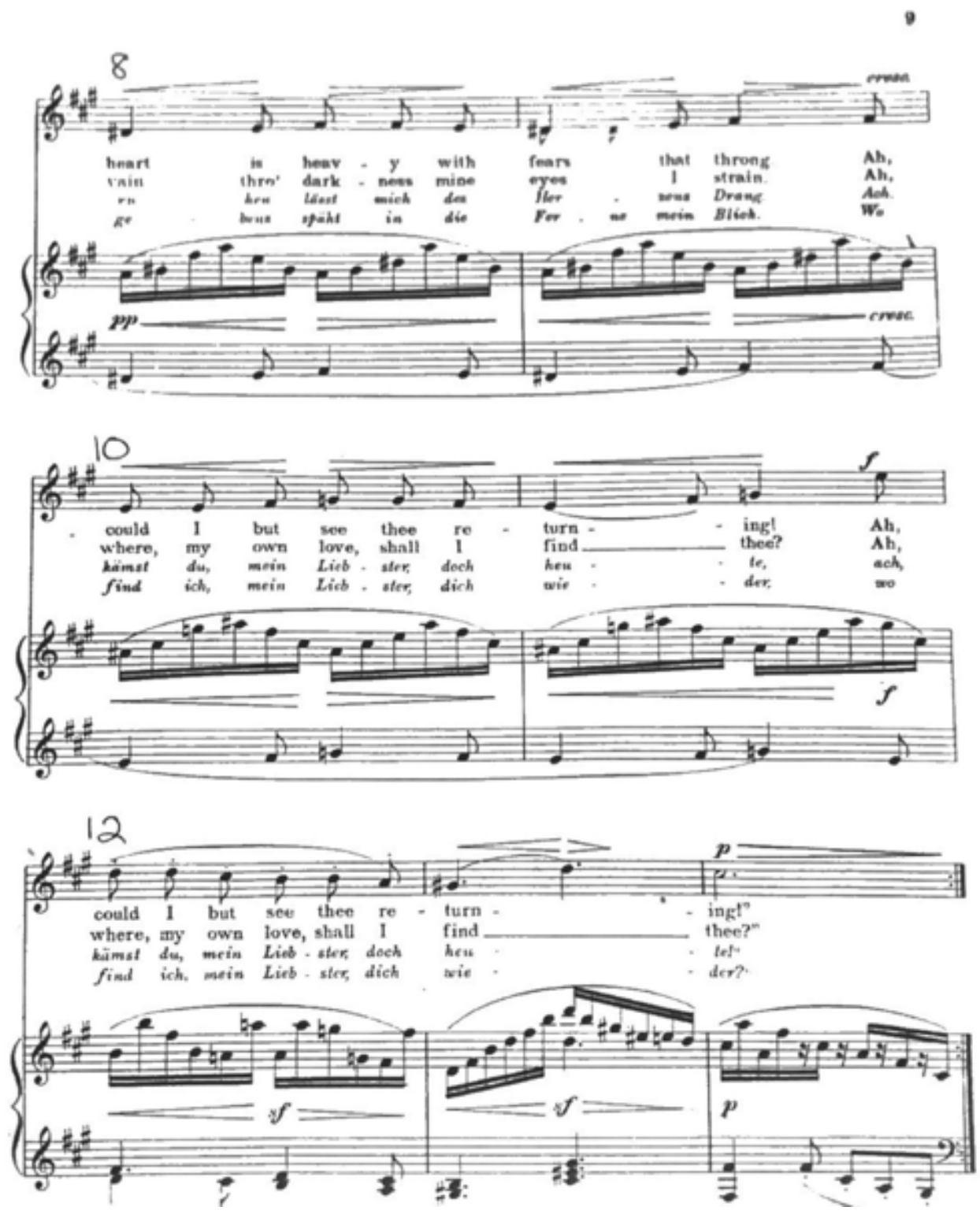

${ }^{79}$ Brahms, Forty Songs, 9. 
In Example 3.8b, you start to see his hold on the singer lift in "Mädchenlied," where out of the entire first page he provides expression and dynamics for mm. 10-12.

Example 3.8b Op. 95, no. 6, "Mädchenlied," mm. 1-14. ${ }^{80}$

\section{Mädchenlied.}

(Heyse. Nach dem Italieniscben.)
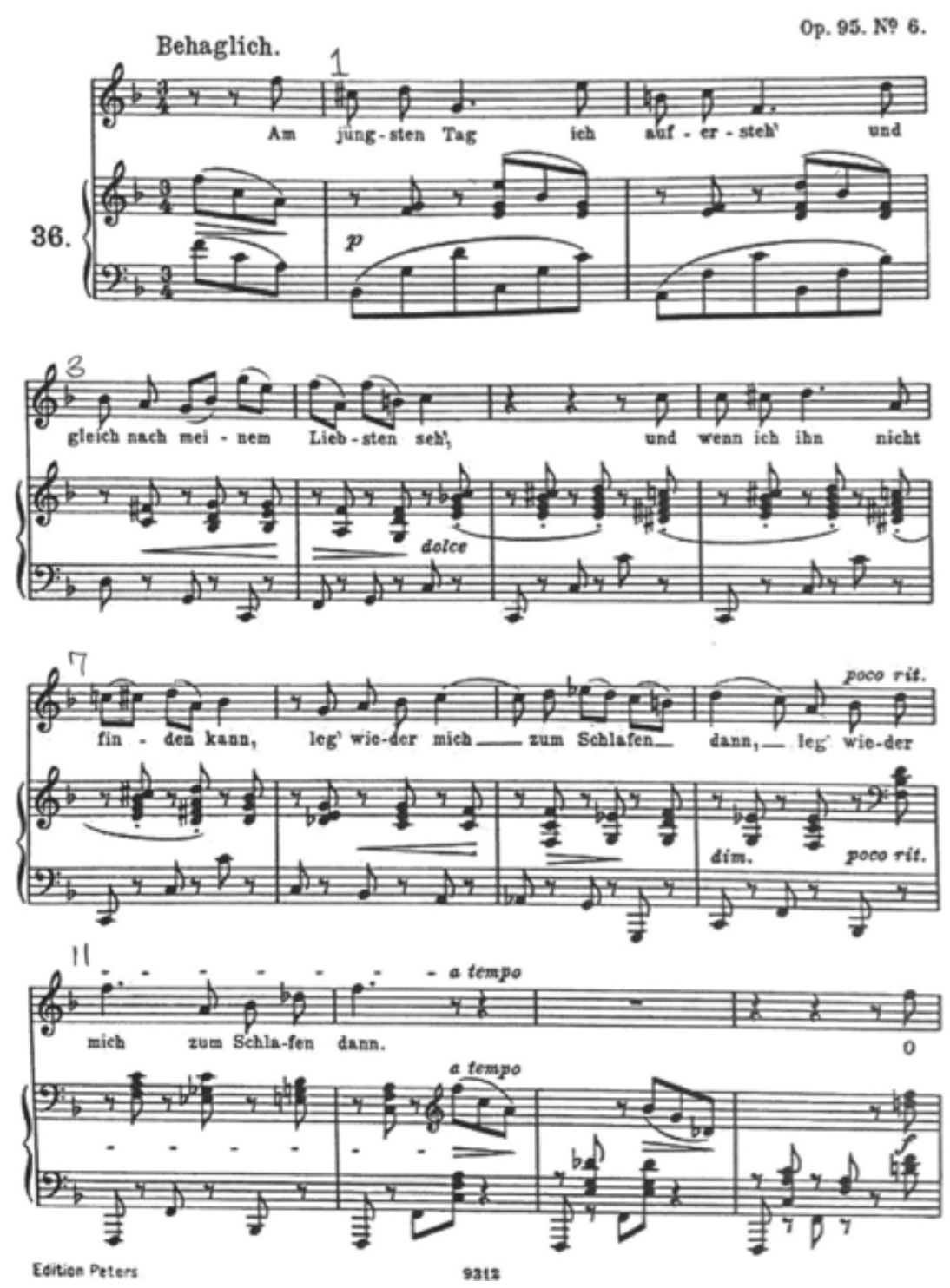

${ }^{80}$ Brahms, Forty Songs, 114. 
By the time you get to his final works like "O Tod, wie bitter bist due" in Example 3.8c, most of the dynamics and expression marks for the voice are not present in the same way.

\section{Example 3.8c Vier ernste Gesänge, "O Tod, O Tod," mm. 1-12. ${ }^{81}$}

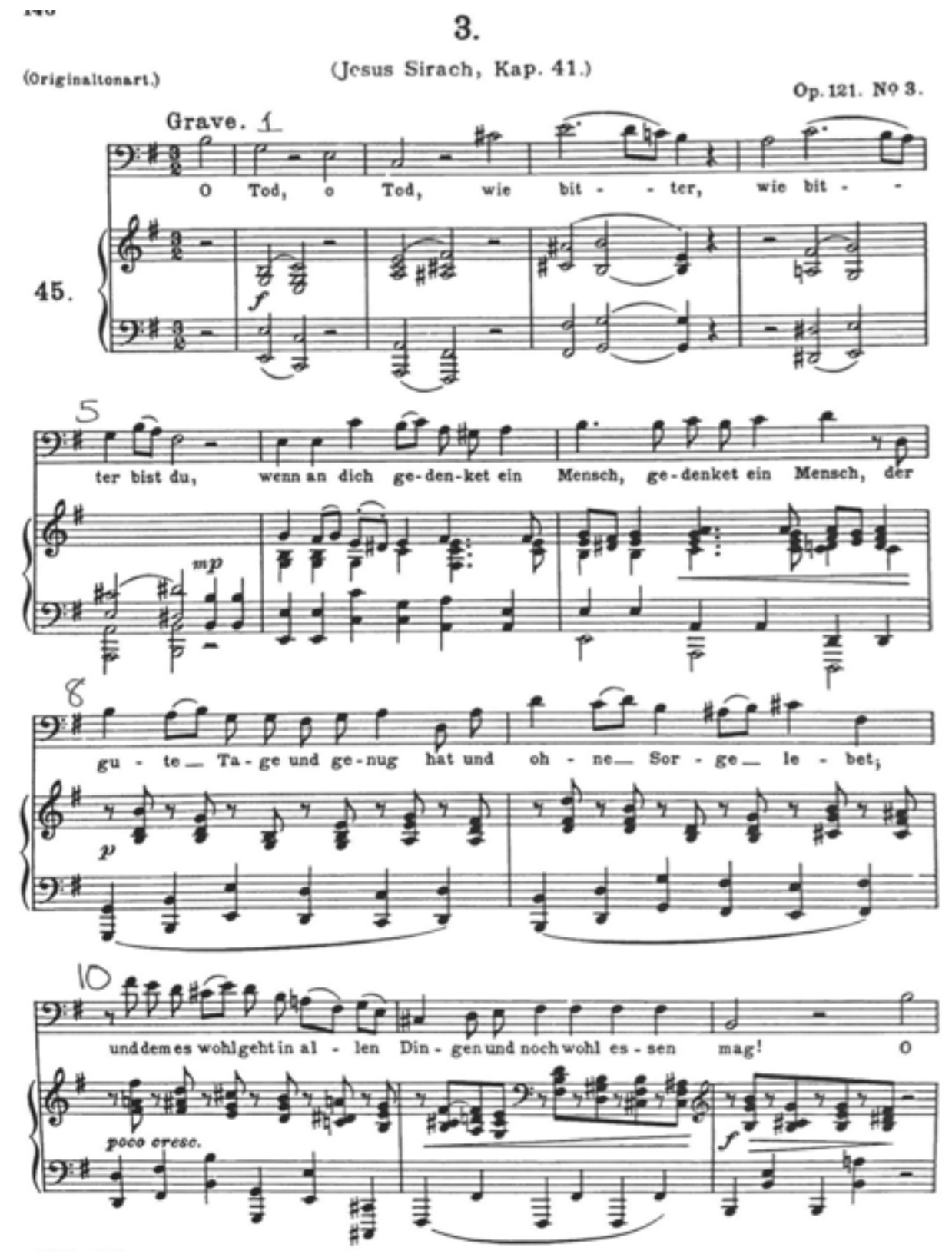

${ }^{81}$ Brahms, Vier Ernste Gesänge, 146. 
When it comes to the form of Brahms's songs we see once again the influence of folk song arrangement. Most of his early arrangements are in strophic form which he would branch out of and come back to later in his mature works. Brahms used the simplicity of strophic form and then slowly started to experiment with different forms eventually composing songs that were modified strophic, through-composed, and more. He would change and modify the form based on the poem and his musical ideas. Stark points out that in his late 1850s and 1860s he is prompted to break away from his folk song influence and use through composed formats to create songs with greater emotional complexity and diversity ${ }^{82}$ Eric Sams calls this period between 1861-1869 his "Song Cycle" period where he composed his only song cycle, The Magelone-Lieder. ${ }^{83}$

The Magelone-Lieder is one of the monumental collections of songs of this period. These songs repeat and flow freely like operatic arias. It is also within this work that we see his music become more condensed and concentrated with thick textures. In this set, Brahms breaks away from his beloved strophic form and calls on more elaborate forms that we would most likely see in instrumental works. Example 3.9 provides a chart that lays out some examples of musical forms Brahms incorporated into the Magelone-Lieder.

\footnotetext{
${ }^{82}$ Stark, A Guide to the Solo Songs, 1.

${ }^{83}$ Eric Sams and British Broadcasting Corporation., Brahms Songs., BBC Music Guides (London: BBC, 1972).
} 
Example 3.9 Form Chart of Op. 33, nos. 1, 3, 4, and 6. ${ }^{84}$

\section{Opus 33/1}

The form is in a large rondo-like form and features a long introduction and postlude.

$\begin{array}{lllllll}\mathbf{A} & \mathbf{B} & \mathbf{A} & \mathbf{C} & \mathbf{D} & \mathbf{A}^{\prime} & \mathbf{A}^{\prime \prime}\end{array}$

$\begin{array}{lllllll}\text { mm. } 41-59 & 60-81 & 82-100 & 101-119 & 120-151 & 152-189 & 190-241\end{array}$

Opus 33/3

This song is laid out in bipartite form with an introduction and postlude.

\begin{tabular}{|c|c|c|c|c|c|c|c|c|c|}
\hline \multirow{3}{*}{$\begin{array}{r}\text { (Intro) } \\
\text { mm. 1-9 }\end{array}$} & \multicolumn{3}{|c|}{$\mathbf{A}$} & \multicolumn{5}{|c|}{ B } & \multirow[b]{2}{*}{ (Post) } \\
\hline & $\longdiv { a }$ & $\mathrm{b}$ & $\overline{b^{\prime}}$ & $\sqrt{c}$ & $\mathrm{c}^{\prime}$ & $\mathrm{d}$ & & $\mathrm{c}^{\prime \prime \prime}$ & \\
\hline & $\|: 10-19$ & :|| 20-32 & $33-44$ & $45-56$ & $67-70$ & $71-85$ & $86-96$ & $97-108$ & $109-115$ \\
\hline
\end{tabular}

This song is in a truncated tripartite form with a postlude at the end.

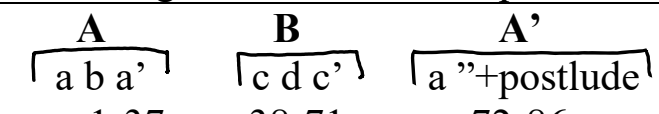

mm.1-37 38-71 72-86

\section{Opus 33/6}

This song is through composed and is structured like a sonata with a succession of connected contrasting movements.

\begin{tabular}{|c|c|c|c|c|c|c|c|}
\hline \multicolumn{3}{|c|}{$\mathbf{A}$} & \multicolumn{2}{|c|}{ B } & \multicolumn{3}{|c|}{ D } \\
\hline $1 \mathrm{a}$ & & $\mathrm{b}$ & & $\mathrm{c}^{\prime}$ & develops a & $\Gamma$ & $\mathrm{d}^{\prime}$ \\
\hline mm. $1-10$ & $11-2$ & $23-43$ & $35-65$ & $66-97$ & $98-108$ & $109-142$ & $143-187$ \\
\hline
\end{tabular}

One could look at the "Magelone" songs as the peak of Brahms's experimentation and concentration. Most of the songs in this set are long, divided into multiple sections, and operatic in its drama and extravagance. It is full of his youthful exuberance and stands alone among the other songs he composed during this time. By 1870s, he had created his own hybrid form that combined the rigor of strophic recurrence with the freedom of through-composition. These adaptations eventual lead to his use of developing variation which Brahms made his own by combining it with a varied strophic form. With Brahms's Varied strophic form, the opening material is varied or developed to provide contrast before it reappears more recognizably to

\footnotetext{
${ }^{84}$ Stark, A Guide to the Solo Songs, 80-90.
} 
round out the design. This allowed him to bring his fondness for strophic song together with his desire for minimal dramatic underlining.

\section{Rhythm and Meter}

Brahms's rhythmic invention is another aspect of his style that is established at an early age. When it comes to his Lieder, most studies that have been done have attributed his metric manipulations to his adaptation of the texts that he used. However, considering that you can find a lot of his rhythmic manipulation in his instrumental works as well these views are a bit shallow. We have already established that Brahms did not lack knowledge in literature and proper text declamation procedure. Throughout his career you see him pushing the boundaries on accent and phrase structure, hypermeter, phrase modifications, syncopation, cross rhythms, and hemiolas. Although his reasoning for implementing these devices did at times have to do with the text setting, that was not always the case. Wing Lau explains that Brahms would use what she calls "Notated Meter Changes" (NMCs) to reorder the strong and weak beats, create hypermetric ambiguity, and vary the pace of poetic declamation for expressive purposes. ${ }^{85}$ Brahms's variety of rhythmic procedures is another one of his style features that was used for expressive purposes. Brahms uses these procedures in his early and his later works.

In her dissertation, Deborah Adams Rohr provides ample detail on the different types of rhythmic inventions that Brahms explored throughout his life. ${ }^{86}$ The examples provided below are just a few of those found in his songs. In "Nachtigallen schwingen" (Op. 6, no. 6), Rohr explains how Brahms's use of syncopation could be a way of demarcating form of the middle

\footnotetext{
${ }^{85}$ Wing Lau, “Composing Declamation Notated Meter Changes in Brahms's Lieder," Music Theory Online 21, no. 2 (2015), 1.

${ }^{86}$ Deborah Adams Rohr, "Brahms's Metrical Dramas: Rhythm, Text Expression, and Form in the Solo Lieder" (Ph.D., University of Rochester, Eastman School of Music, 1997).
} 
section and creating some text painting. ${ }^{87}$ In addition to his use of syncopation, one of his favorite metrical and hypermetrical devices, the use of $3+2$, surfaces. Example 10 provides the three stanzas of text. As we explored in chapter 2, the outer stanzas, the poet describes a happy and exciting environment. However, in the middle stanza the poet shifts their focus inward to describe their unfulfilled longings. In this ABA' song form, the A section has continuous triplets in both hands of the piano. When you couple this with the moments that the voice has eighth notes, you feel the 3 against 2 effect.

\section{Example 3.10 "Nachtigallen schwingen" (August Heinrich Hoffmann von Fallersleben).}

Nachtigallen schwingen lustig ihr Gefieder, Nachtigallen singen ihre alten Lieder.

Und die Blumen alle, sie erwachen wieder

Bei dem Klang und Schalle aller dieser Lieder.

Und meine sehnsucht wird zur Nachtigall

Und fliegt in die blühende welt hinein,

Und fragt bei den blumen überall,

Wo mag doch mein, mein Blümchen sein?

Und die Nachtigallen schwingen ihren reigen

Unter Laubeshallen zwischen blütenzweigen, Von den blumen allen aber ich muß schweigen.

Unter ihnen steh' ich Traurig sinnend still:

Eine Blume she ich, die nicht blühen will.

Example 3.11a provides the first three full measures of "Nachtigallen schwingen." In measure 3, Brahms uses a 3 against 2 rhythmic pattern between the voice and piano.

\footnotetext{
${ }^{87}$ Rohr, "Brahms’s Metrical Dramas," 113-114.
} 
Example 3.11a Op. 6, no. 6, "Nachtigallen schwingen," mm.1-3. ${ }^{88}$

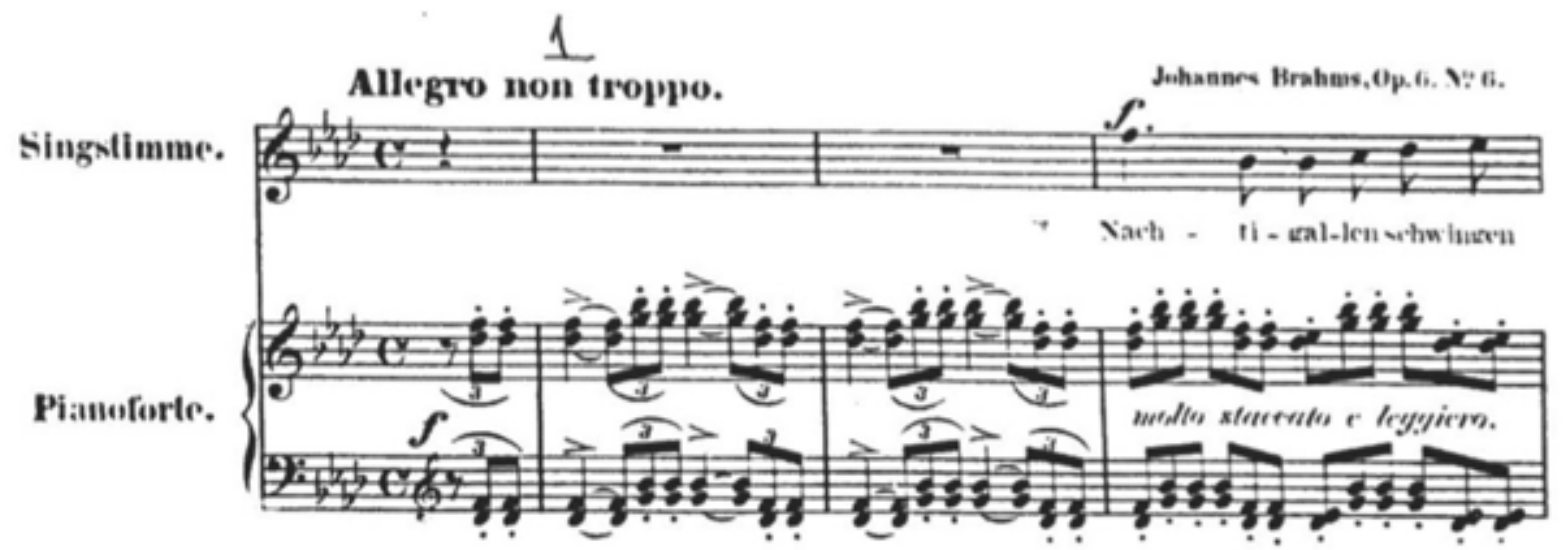

If we recall Eric Sams translation of the poem, we see that the poet is singing in wonder and joy of all the beauty of nature they are beholding. When the singer ventures into the second stanza, Brahms's musical setting completely changes. In this section of the song the text has moved from joy to longing for a loved one. Example 3.11b shows the B section of "Nachtigallen schwingen," when music slows and becomes less thick and excited as the A section. Low pulsing chords in the bass have not been present until now, as well as a syncopation that comes out the piano. ${ }^{89}$ When juxtaposed with the voice, it creates a bewildering tension that is appropriate when you consider that the singer is in the midst of all this beauty and at the same time longing for her own flower (beloved).

\footnotetext{
${ }^{88}$ Brahms, Sechs Gesänge, 20.

${ }^{89}$ Rohr, "Brahms’s Metrical Dramas," 113-114.
} 
Example 3.11b Op. 6, no. 6, "Nachtigallen schwingen" mm. 16-26. ${ }^{90}$
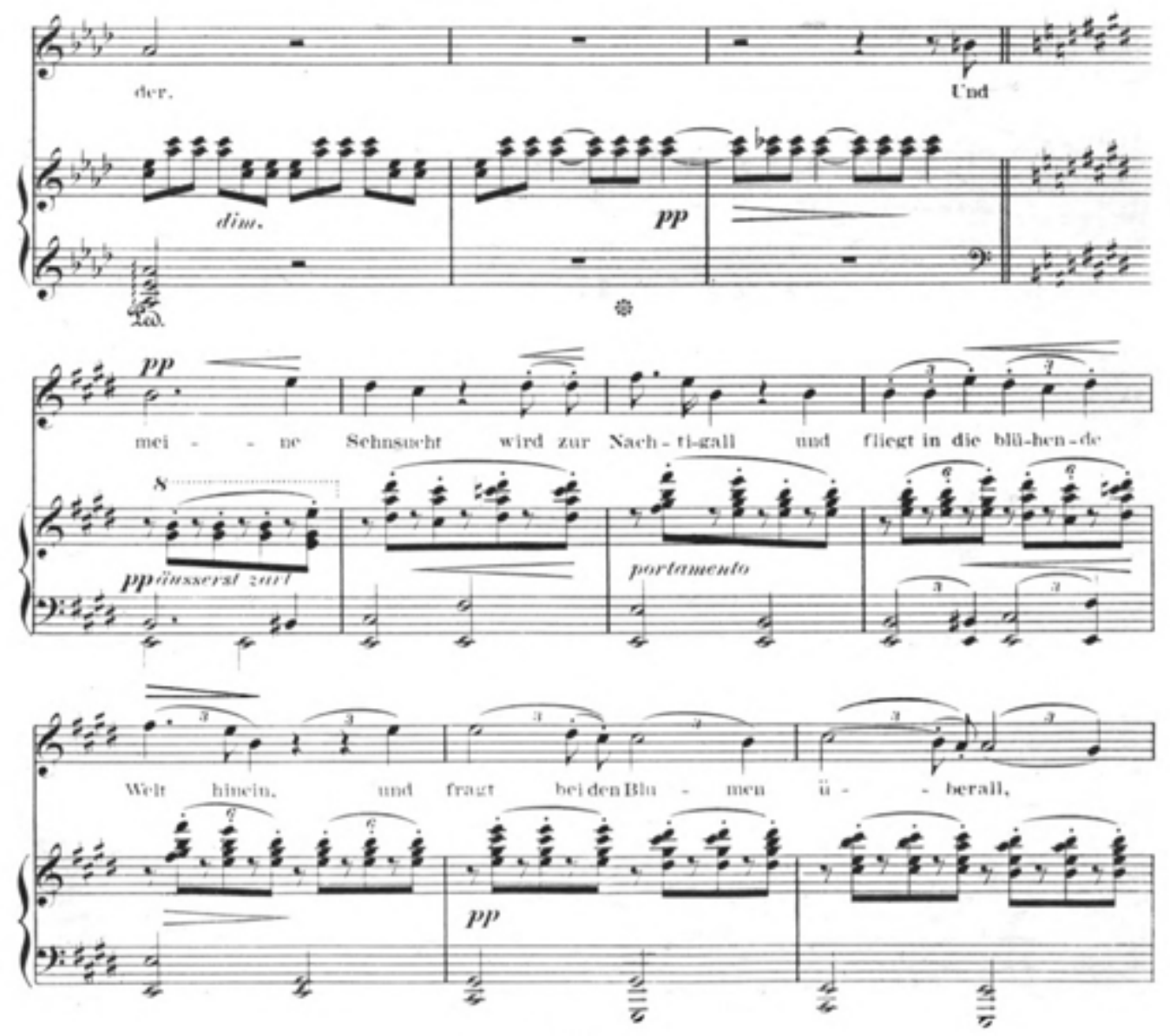

In Example 3.11c, we see the last four measures of "Nachtigallen schwingen," when this point is solidified at the end of the song after the maiden sings that she can see one flower that refuses to bloom. After she sings this longing phrase, the piano recalls the syncopation that occurred in the B section as a reminder of the longing that was experienced in the B section.

${ }^{90}$ Brahms, Sechs Gesänge, 21. 
Example 3.11c Op. 6, no. 6, "Nachtigallen schwingen" mm. 48-53. ${ }^{91}$

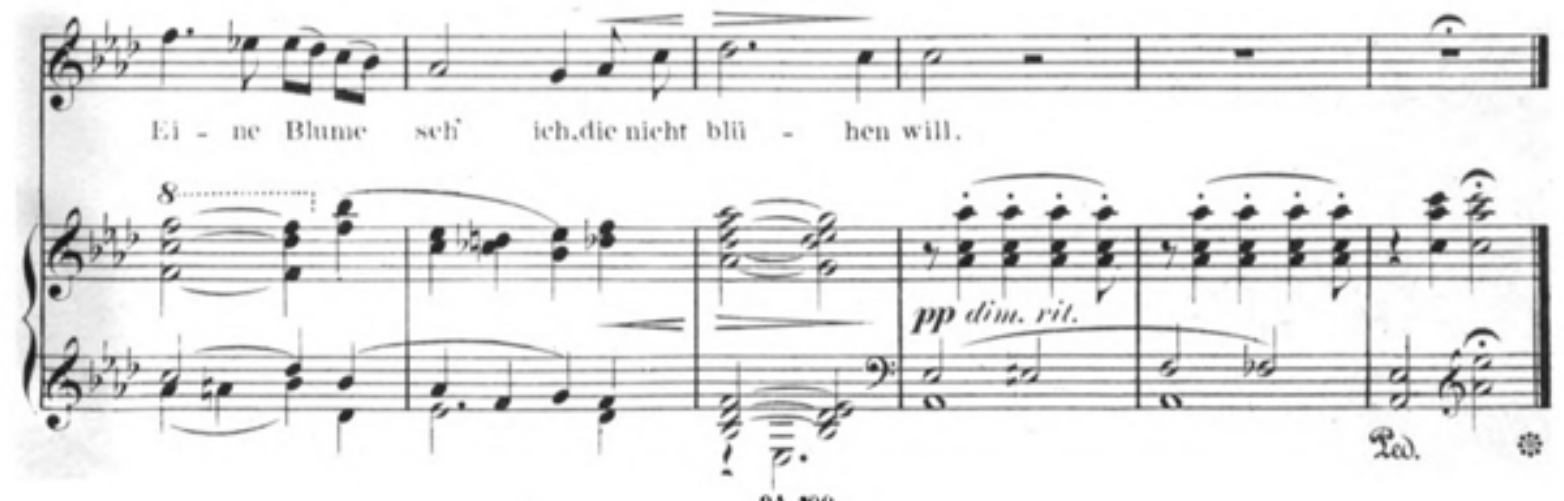

Another interesting manipulation of rhythm that Brahms implements is the use of phrase

expansion. In "O kühler wald” (Op. 72, no. 3), Brahms extends the image of expansion even further to mirror the echo and expanse of the forest that the poem is about. Rohr provides a helpful chart in Example 3.12a to show how Brahms continuously expands the phrases of the poem.

Example 3.12a Phrase Structure of Op. 72, no. 3, "O kühler Wald."992

Phrase

I

2

3

4
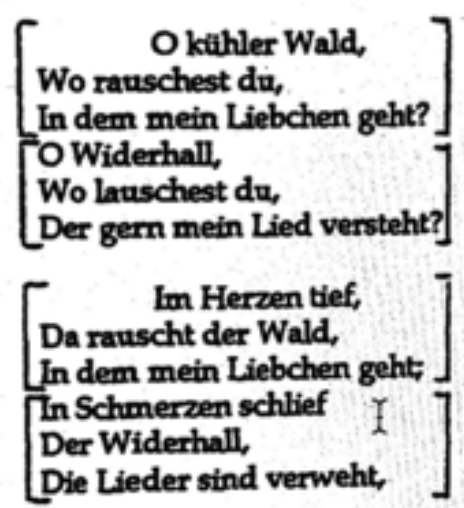

number of bars

4

5

6

7
(6)

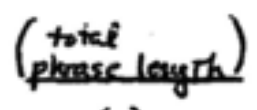

(5)

(6)

(8)

${ }^{91}$ Brahms. Sechs Gesänge, 23.

92 Rohr, "Brahms's Metrical Dramas," 94. 
Brahms expands each phrase by a measure, augmenting the rhythm of the melody and repeating text. In Example 3.12b you see how Brahms sets the first phrase of the text. As you can see it is balanced in 4 bars. In Example 3.12c, Brahms has stretched the last phrase out to 7 bars that takes up the entire page.

\section{Example 3.12b Op. 72, no. 3, "O kühler Wald," mm. 1-5. ${ }^{93}$}

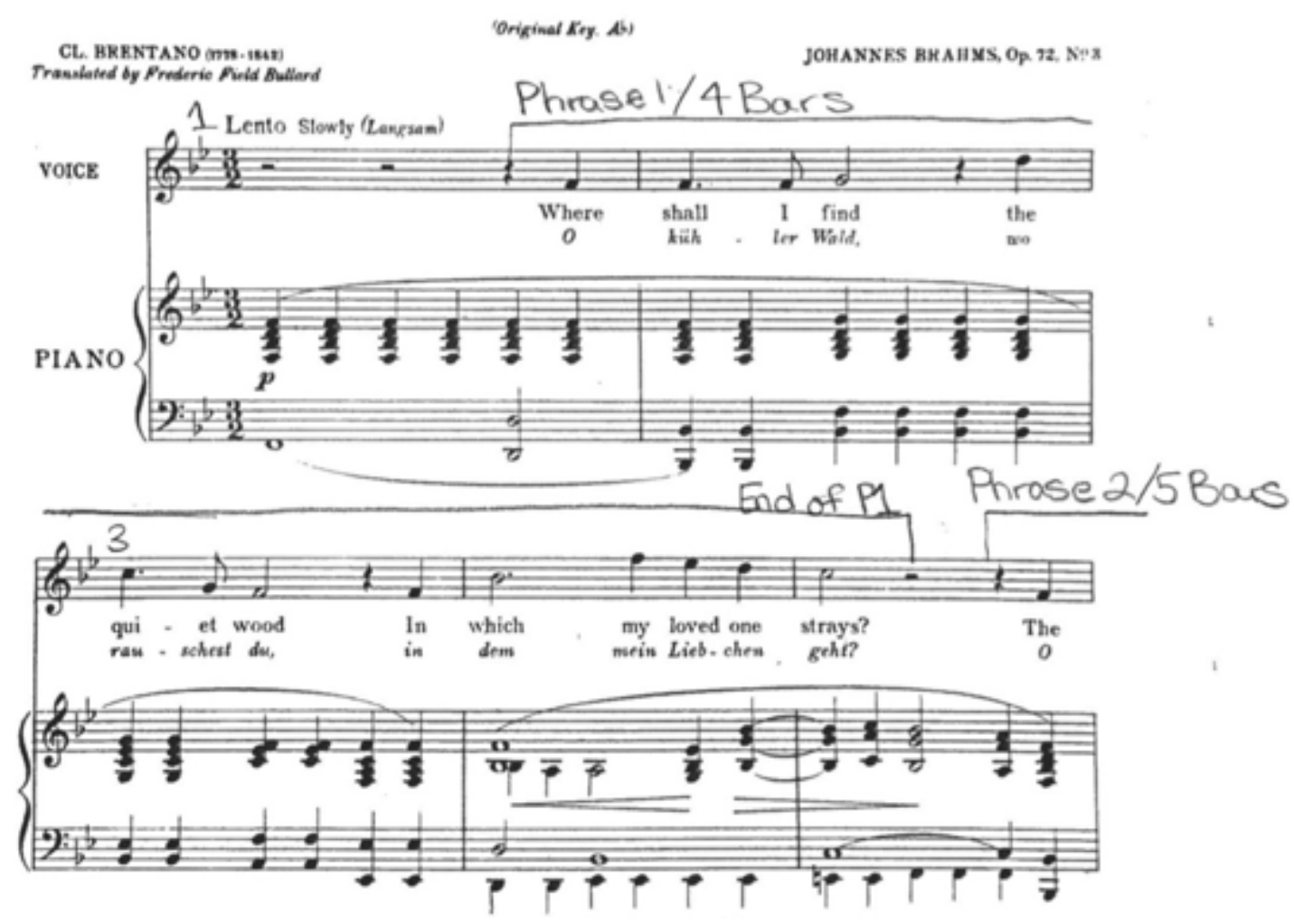

In this example we can see a trait that really does typify or encompass Brahms's entire compositional process. To many, Brahms is seen as a bridge between the Classical era, of which he held so dear, and the Romantic and beyond. It is easy to see the evidence of this in his rhythmic use. Brahms is 44 at the time that he composed "O kühler Wald," and he is still tapping

\footnotetext{
${ }^{93}$ Brahms, Forty Songs, 86.
} 
into the many different ways that he can stretch the balanced and even structures that the Classical era promoted, while still not to the point that it breaks away from it entirely.

Example 3.12c Op. 72, no. 3, “O kühler Wald," mm. 18-25..$^{94}$
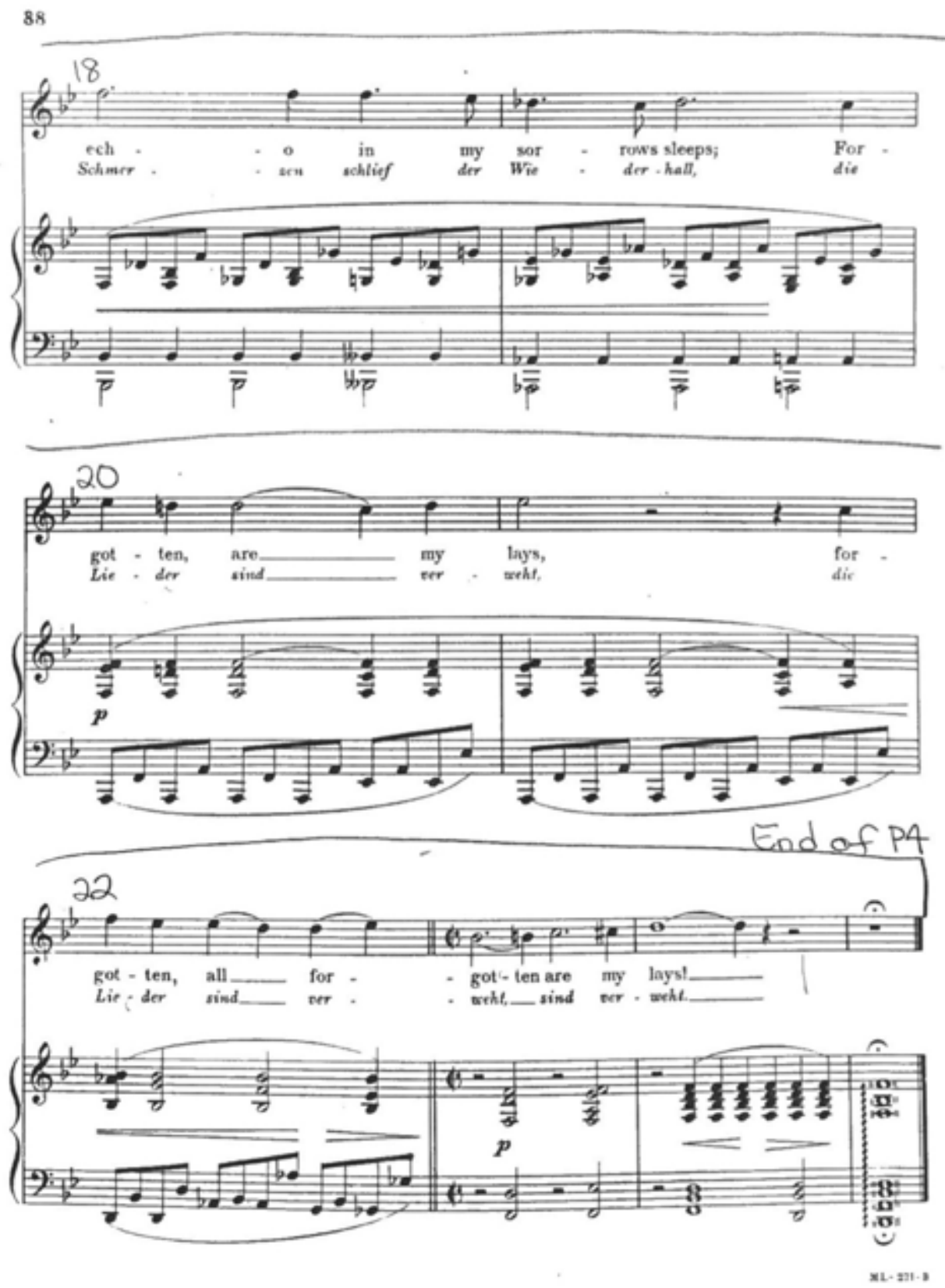

${ }^{94}$ Brahms, Forty Songs, 88. 
These rhythmic manipulations and devices are present from the beginning and end of his art songs. In Example 3.13, we see his uses of rhythmic displacement in "O Tod, wie bitter bist du." In Example 3.13a, Brahms displaces the anacrustic rhythm by moving the start of the line from the upbeat to the downbeat in $\mathrm{m}$. 4. Okuda suggests that to the ear this creates what seems to be a meter change. ${ }^{95}$ We perceived the $3 / 2$ meter in the first two measures, but in measure 4 , we perceive it as $4 / 2$, and then $5 / 2$ from the second beat of measure 4 to measure 8 .

Example 3.13a Vier ernste Gesänge, "O Tod, O Tod," mm. 1-7.96

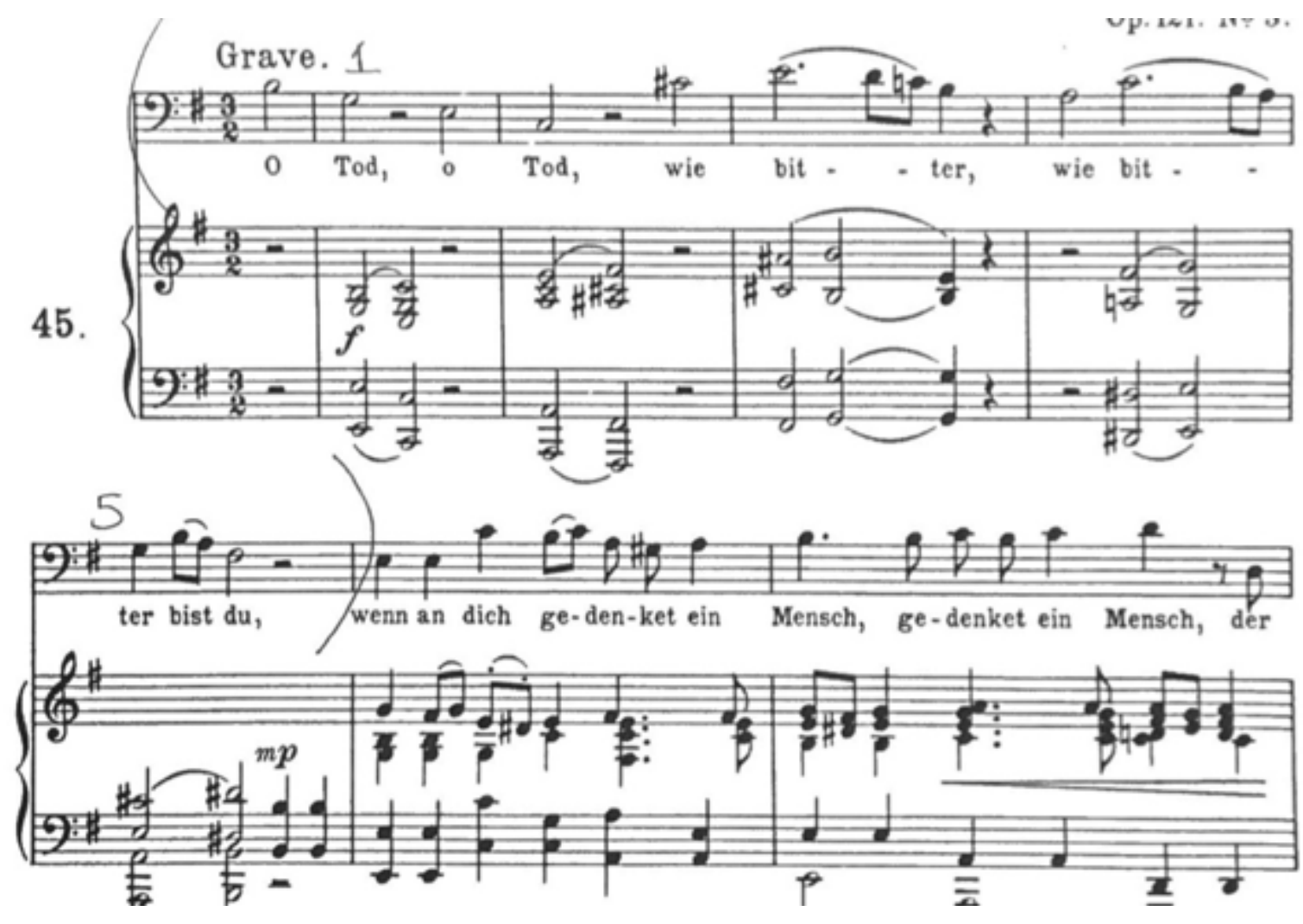

${ }^{95}$ Okuda, "Brahms's Late Song Style," 71.

${ }^{96}$ Brahms, Vier Ernste Gesänge, 146. 
In Example 3.13b, Brahms brings back his use of syncopation to create tension again between the voice and piano in $\mathrm{mm}$. 8-9. He intensifies this in $\mathrm{mm}$. 29-32 where he creates a hemiola in the piano to provide a $2+3$ feeling between the voice and piano.

Example 3.13b Vier ernste Gesänge, "O Tod, O Tod," mm.8-9.97

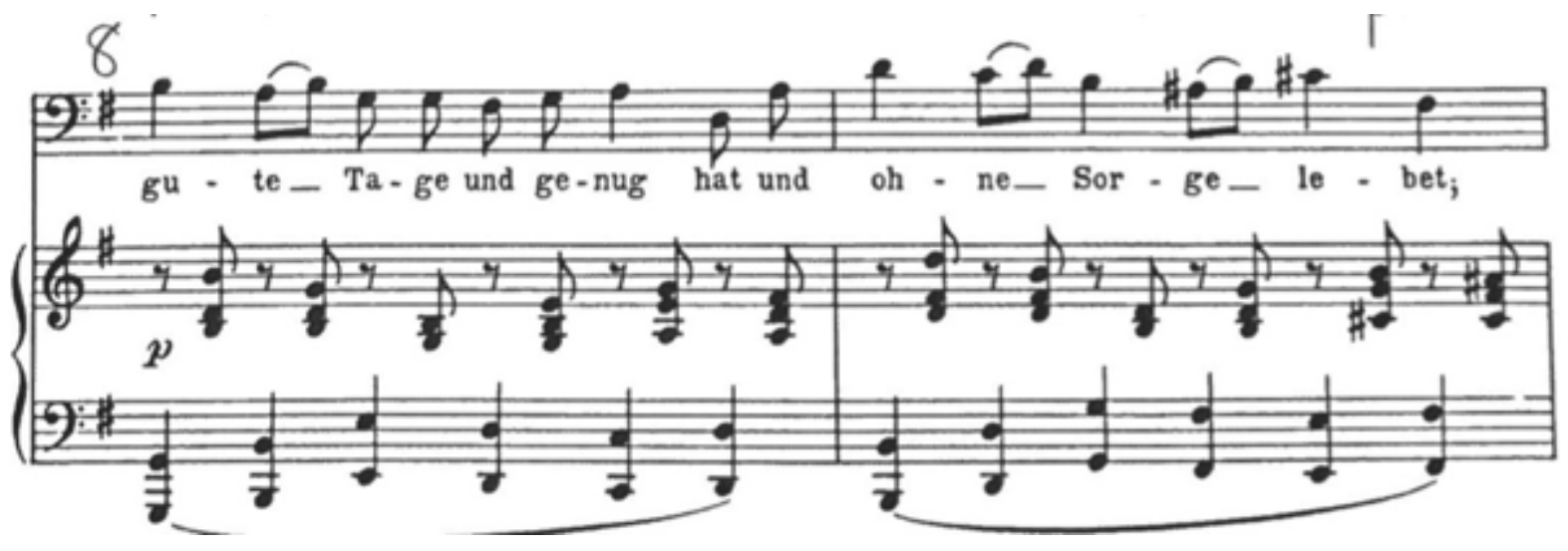

Example 3.13c Vier ernste Gesänge, “O Tod, O Tod,” mm.29-32. ${ }^{98}$

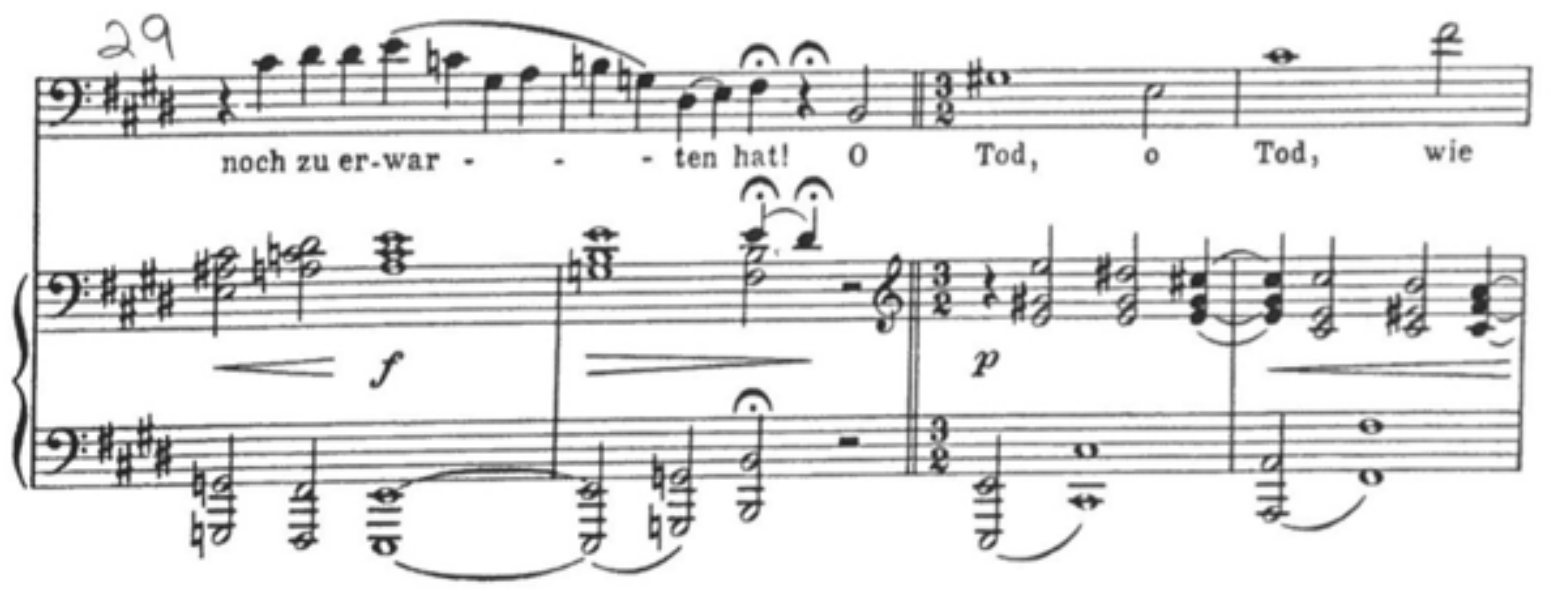

\footnotetext{
${ }^{97}$ Brahms, Vier Ernste Gesänge, 146.
}

98 Brahms, Vier Ernste Gesänge, 148. 


\section{Conclusion}

After reviewing all of these examples, it seems that, although there are moments in Brahms's Lieder output when he refined and even branched out into different styles, his later art song style did not undergo a drastic shift or rupture of musical style. Yes, he had moments of refinement in some features of his style like harmonic development. He also broke away from the beloved strophic and varied strophic forms found in the Magelone-Lieder and many of his other songs. However, it would seem that the foundation on which he built his style during his early years or "first maturity" continued to serve as the foundation for the rest of his career. Brahms has many interesting features of his Lieder style that he used depending on the needs of the songs or particular musical project. The completely different direction found in the Magelone-Lieder was not necessarily a style change. When he tapped into different rhythmic patter and manipulations or ventured into different texts sources like his does in the Vier ernste Gesänge, it is hard to mark these moments in his works as stylistic changes considering that Brahms seems to call on these unique techniques whenever they suit his particular compositional needs. The devices that we see Brahms consistently calling on have already been part of his musical arsenal well before his later years. In the next chapter, we will explore some possible reasons why Brahms did not feel the need to be more experimental or exploratory when considered in the context of the broader nineteenth-century Lieder repertoire and how the songs of Brahms might be compared to those of Franz Liszt and Hugo Wolf. 


\section{Chapter 4}

\section{Brahms among Other Lied Composers}

The history of the $19^{\text {th }}$ Century lied is a story of how composers chose to balance the forces of poetry and music. ${ }^{99}$

The nineteenth century has been seen in many ways as what Lorraine Gorrell calls the "verbal age." 100 During this time, music periodicals became popular as articulate composers were eager to write about themselves, their music, and their ideas. Composers such as Schumann, Berlioz, and Wolf often served as music critics in periodicals. Franz Liszt wrote biographies of Chopin and others, and many composers also kept diaries, and wrote countless letters and autobiographies. There were strong musical changes that developed during the "verbal age." This growth that occurred in the nineteenth century was made possible because of literary events in the eighteenth century. At the end of the eighteenth century, there was an outpouring of lyric poetry that culminated in the works of Johann Wolfgang von Goethe (1749-1831) and others. A new importance grew out of exploring the link between poetry and music in the German Lied. This of course, became part of the nineteenth century trend of blending different art forms. Although the art of blending literature and music was not new, the culminating events of the nineteenth century brought the relationship between poetry and music to a new level. For composers such as Schumann and Wolf the search for suitable texts proved to be an exhaustive and frustrating task at times. Wagner chose to solve this problem by writing his own libretti. Most lieder composers tended to stay away from opera as a medium of inspiration. Most felt that their gifts flowed better in more intimate settings and were not necessarily equipped to take on

\footnotetext{
${ }^{99}$ Gorrell, The Nineteenth-Century, 19.
}

${ }^{100}$ Gorrell, The Nineteenth-Century, 10. 
the skills that opera required. As we know, Brahms wrote no operas, and the operas of Schubert, Schumann, and Wolf were not especially well received.

Nineteenth-century musicians, unlike musicians of the previous centuries, were normally not progenies of great musical families. They did not come from parents who could pass along the musical knowledge of generations. While Brahms received training from his father who was a string and wind player, other composers and musicians were note so fortunate. Robert Schumann's father was a doctor, while Hugo Wolf was the son of a leather manufacturer. Gorrell points that some this lack of early music education could have led to the free treatment of musical form, extension, or the breakdown of tonal harmony in the music of many notable musicians of this time. Many song composers during this time viewed the song as a free form that demanded little sophistication or long-term development.

Gorrell defines the lied "as a genre that melded poetry and music into a unique relationship in which piano and voice were closely linked to the poetic phrase, and the musical elements such as melody, harmony, and rhythm of the music were crafted to create the mood of the poem they interpreted." ${ }^{101}$ Each composer had their own individual way they would tap into these elements. However, in bringing together these two different art forms, a controversy was born as poets, musicians, and critics debated on how to maintain a balance between the two. Some scholars believed that a poem carried more authority than a libretto, and that it had rights that should not be ignored. If you think about the fact that a libretto is written specifically for the purpose of an opera, and a poem is written to stand alone as its own art form, you can see the validity of this argument. However, there were many composers who did not feel this way and took many liberties with the poems they used. Throughout the history of music, there have been

${ }^{101}$ Gorrell,The Nineteenth Century, 15. 
many debates and discussion over how the music and poem should weigh against each other in a

song. While both should be important and equal partners in creating the song, can one carry more weight and importance? Arnold Schoenberg shares his strong opinion on the subjects of text vs. music in his book, Style and Idea:

I discovered in several Schubert songs, well-known to me, that I had absolutely no idea what was going on in the poems on which they were based. But when I had read the poems it became clear to me that I had gained absolutely nothing for the understanding of the songs...since the poems did not make it necessary for me to change my conception of the musical interpretation.... On the contrary,... without knowing the poem, I had grasped the content, the real content, perhaps even more profoundly than if I had clung to the surface of the mere thoughts expressed in words.... Inspired by the sound of the first words of the text, I...composed many of my songs straight through to the end without troubling myself in the slightest about the continuation of the poetic events, without even grasping them in the ecstasy of composing... Only days later I thought of looking back to see just what was the real poetic content of my song...To my greatest astonishment,... I had never done greater justice to the poet than when, guided by my first direct contact with the sound of the beginning, I divined everything that obviously had to follow this first sound with inevitability.... It became clear to me that the work of art is like every other complete organism. It is so homogenous in its composition that in every little detail it reveals its truest, inmost essence. ${ }^{102}$

There is some truth and also some issues with this opinion. Although it is true that one could most likely grasp the subject of the poem just from reading the first couple of lines, you run the risk of missing out on details of the poem (analogies, metaphors, simile, etc.) by taking a superficial approach to it. Perhaps this is one of the issues that the text vs. music debate is stemmed from. Where some composers felt that setting a poem to the overall subject matter of the poem was enough, others realized that by doing this you miss out on all the ways you can bring the poem to life through the music by having more intimate knowledge of it. By choosing

${ }^{102}$ Arnold Schoenberg, Style and Idea (New York,: Philosophical Library, 1950), 4. 
to only grasp the subject and structure of the poem superficially, you are not in fact doing equal justice to both mediums.

When words are brought into a musical composition, listeners are automatically drawn to certain ideas. A composer can choose to enhance the meaning of words with their music and even emphasize the quality of particular words, making the music the dominant force between the poetry and music. It can have the ability to enhance, remove, or obscure the words of the poem. Here is where the debate begins. While you have some composers, who want to honor the integrity and artistry of the poem, others would prefer to have the freedom to use the poem how they pleased. At the end of the nineteenth century, Wolf and other composers like him would give more authority to the poem, while some composers like Brahms didn't mind obscuring the text a bit a fit his musical ideas. Gorrell states that Brahms would reflect on the poem for a while before he began the process of composing a song. ${ }^{103}$ The text would stimulate his creative process and bring him many musical ideas that often reflected the rhythm of the poem itself. He had an appreciation and respect for poetry, but he did not allow it to hinder his journey into a manipulative direction. He allowed it to inspire him, but not restrict him. These types of liberties have caused some critics to go as far as to question whether musicians should even be allowed to set a fine poem to music, arguing that if the poem is already a fine work of art then why should anyone feel the need to improve it.

\section{Politics and Movements (Rationalism, Nationalism, Romanticism)}

There were many movements that influenced the nineteenth century. The rejection of the eighteenth-century rationalism spurred a desire for fantasy, individuality, isolation from society,

${ }^{103}$ Gorrell, The Nineteenth-Century, 19. 
nature, love of the past. This glorification of love and nature led to the movement of Romanticism. Although historians point out that those qualities which are defined as either classic or romantic can be found in all musical eras, Romanticism was a very important concept in the German art song. A wanderer outside of society, immersing oneself in nature, love of the past, and love itself are all romantic themes that saturate the German lied. Two good examples that represent this are Franz Schubert's Winterreise and Die schöne Müllerin.

Another factor that influenced nineteenth-century musicians was nationalism. The political world during this time was in the midst of revolutionary tension which had an effect on the development of opera and song. Most German-speaking people had little awareness of their own identity since the French culture had been the most admired and influential. However, toward the end of the $18^{\text {th }}$ Century, German-speaking people began experiencing a phenomenal literary and philosophical revival with the help of Gotthold Lessing. Lessing helped move German authors away from their imitation of French literary models. They now had at their disposal prominent figures of literature, theatre, philosophy, music, and theology. Some of these figures include, but are not limited to; Goethe, Schiller (1759-1805), Immanuel Kant (1724-1804), Georg Wilhelm Friedrich Hegel (1770-1831), Ludwig van Beethoven (1770-1827), Friedrich Schleiermacher (1768-1834), and many others. This movement inspired people to immerse themselves in their own heritage, folk poetry, folk music, myths, and history. Lessing also helped them find interest and embrace Shakespeare, Classical Greece, and Rome. German writers now started to pursue their own linguistic and intellectual identity and got rid of the bonds of the French Enlightenment, and the movement that encouraged human intellect, reason, and science.

These factors contribute to the development of the German Lied. Composers such as Robert Schumann, Robert Franz, and Johannes Brahms would take these traditions and 
incorporate them into their songs in their own individual way. The growth of the nineteenthcentury German Lied would begin to stimulate the development of other national styles of song including French melodies, and Italian art songs

The 1848 revolution in France took place and begin to affect the whole of Europe a new movement known as Realism would appear. Realism would take its hold on both politics, literature, and poetic subject. The dreamy sentiments of Romanticism would start to wane having an interesting effect on the German lied. Gorrell stated, "Hugo Wolf's early poetic choices reflect an ambivalence to the romanticism of the past and a move toward the pragmatism of the present." ${ }^{\prime 104}$ Even when he chose poetry by Eichendorff or Goethe, he would often choose poetry that presented a more realist message.

\section{Brahms's Place in the Nineteenth Century}

It is believed that Brahms's private nature had a strong impact not only on how he presented himself to the world, but also how he presented his music to the world. Some scholars have felt that the only way to judge him, was to find his personality in his music. Gorrel states that, "Brahms holds a unique place in the history of the nineteenth century art song because he presents the listener with so many contradictions." ${ }^{105}$ One of these contradictions that has been pointed out is how the poetry seemed to function in a secondary place in the song. He is recognized as one of the most technically skilled composers of the century, and yet he kept himself bound to the folk song models and considered them to be the superior form. While his contemporaries were venturing into experimental and modern models of song, Brahms continued to call on the classic models of the past. About half of his songs are harmonized folk melodies or

\footnotetext{
${ }^{104}$ Gorrell, The Nineteenth-Century, 50.

105 Gorrell, The Nineteenth-Century, 258.
} 
songs based on folk poems. He continuously incorporates Baroque techniques such as pedal point, counterpoint, and augmentation. At times his contrapuntal techniques were modified to suit the nineteenth-century vocabulary. Gorrell explains that his chord progressions recall a Renaissance quality in their simplicity and in how he avoided $7^{\text {th }}$ chords. ${ }^{106}$ The examples in chapter 3 show Brahms carrying and refining these techniques from the beginning to the end of his career. From the imitation that is shared between the bass line and voice in "Liebestrue," to the pedals that occur on the dominant of "Denn es gehet," Brahms took the models from previous eras, incorporated some of the bold harmonic vocabulary of the nineteenth century, and yet kept it all within the boundaries of traditional or Classical tonality. He showed only a minor glimpse of beauty, love, and humor. He was subtle in the way that he used his wealth of skill and knowledge which in a way was a mirror of his personality. With Brahms, you only saw, or heard the tip of the iceberg.

During the summer of 1896, Brahms was diagnosed with jaundice, however toward the end of that same year his doctor re-diagnosed him with cancer of the liver. His last public appearance was on 3 March 1897. He attended a concert where Hans Richter conducted Brahms's Fourth Symphony. With it being his last public performance, it was fitting that there was a standing ovation after every movement. His condition would gradually get worse until he died on 3 April 1897 in Vienna.

\section{A Brief Look at Franz Liszt's Late Song Style}

The Hungarian Franz Liszt (1811-1886) is counted as another monumental figure of the nineteenth-century Lied. Gorell explains that his many travels introduced German art song to the

${ }^{106}$ Gorrell, The Nineteenth-Century, 271. 
rest of Europe ${ }^{107} \mathrm{He}$ traveled from England to Russia where he played transcription of songs written by Schubert, Schumann, Franz, Beethoven and Mendelssohn. Like Brahms, he frequently incorporated arpeggiated chords as the foundation for his accompaniments. However, his piano writing often exploited the range and color possibilities of the piano more successfully than Brahms. Gorrell explains how Liszt desired to have tonal freedom. "Through sequences, chromaticism, enharmonic spellings of notes and chords, and sudden shifts into keys that are a third away form the home key, he achieved amazing tonal freedom."108 Another feature that became prominent in his accompaniment was the way he would leave the piano out to create silence and isolation of the singer. He most commonly wrote songs about love and death. In his later songs the subjects of death, depression and religion would take over his output. In both the early and late songs, there is a love of harmonic exploration, intense chromaticism and tonal ambiguity. As he got older this harmonic experimentation increased. Like Brahms, Liszt was seen as a composer who could be careless with how he set poetry, however this improved as his works matured.

Towards the end of his life, Liszt suffered through the deaths of many of his family members and close acquaintances including his son and daughter. After these events Liszt turned to a life of solitude at the monastery Madonna del Rosario where he received several minor orders. His physical health would start to deteriorate from suffering from many different ailments including dropsy, and towards the end of this life, cataracts. This caused him a tremendous amount of distress when he tried to read, write letters, and above all compose. Despite suffering through all these circumstances, Liszt continued to composed songs up until the year of his death in 1886 .

\footnotetext{
${ }^{107}$ Gorrell, The Nineteenth-Century, 244.

${ }^{108}$ Gorrell, The Nineteenth-Century, 251.
} 


\section{Late Songs of Liszt}

Below are some examples of Liszt late songs and their poems. The musical examples display some of his late style traits presented in the previous discussion. "Ihr Glocken von Marling" is one of the most unique songs of Liszt late song collection. In the translation provided by Emily Enzust, the narrator praises the church bells of Marling where Emil Kuh spent the last years of his life. ${ }^{109}$ Carol Kimball explains that during this time in Liszt life, he had received minor orders in the church, and that this could be the reason the text and the music both reflect a "religious mysticism."110

\section{Example 4.1 Liszt, “Ihr Glocken von Marling” (Emil Kuh).}

Ihr Glocken von Marling, wie braust ihr so hell

Ein Wohliges Lauten, als sänge der Quell

Ihr Glocken von Marling, ein heil' ger Gesang

Unwallet wie shützend den weltlichen Klang,

Nehmt mich in die Mitte der tönenden Flut

Ihr Glocken von Marling, behütet mcih gut

Example 4.2 shows how Liszt brings the text to life in the score of "Ihr Glocken von Marling." The bells of the poem are represented in note clusters in the piano accompaniment. He also sets the accompaniment almost entirely in treble clef. Kimball points out that this song contains his late songs traits in his implementation of unresolved $7^{\text {th }}$ and $9^{\text {th }}$ chords and a few moments where voice in unaccompanied on the last page from $\mathrm{mm} .43-48 .^{111}$ This song is also a good example of how his style is moving toward impressionism. With the repeated eight note

\footnotetext{
${ }^{109}$ Emily Enzust, "The liederNet Archive: Texts, and Translations to Lieder, Mélodies, Art Songs, Choral Pieces, and Other Vocal Music," http://www.lieder.net/.

${ }^{110}$ Kimball, A Guide to Art Song, 97.

${ }^{111}$ Kimball, A Guide to Art Song, 97.
} 
clusters being blurred by the use of pedal, this song creates a serene, tranquil and impressionistic quality. 


\section{Example 4.2 Franz Liszt, "Ihr Glocken von Marling," mm 1-20.112}

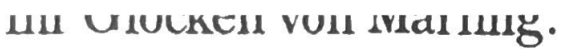

Gedicht ron Emil Kuh.

Fürstin Marie von Hohenlohe-Schillingsfürst gewidmet.
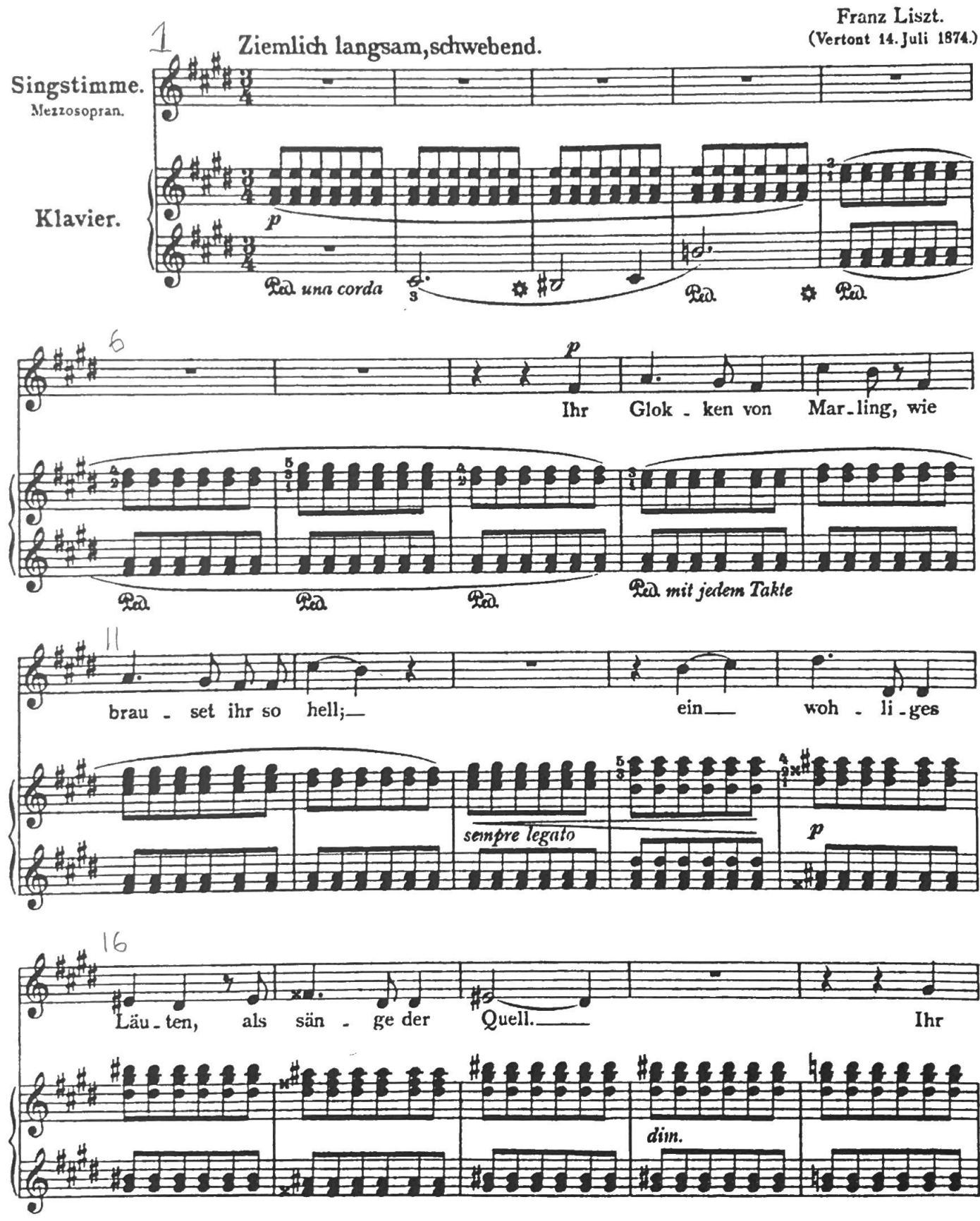

F. L.V11 81.

${ }^{112}$ Franz Liszt, Franz Liszt: Musikalische Werke, ed. Peter Raabe (Leipsig: Breitkof\&Härtel, 1922). 
Example 4.2, continued. Liszt, "Ihr Glocken von Marling” mm. 21-40.113
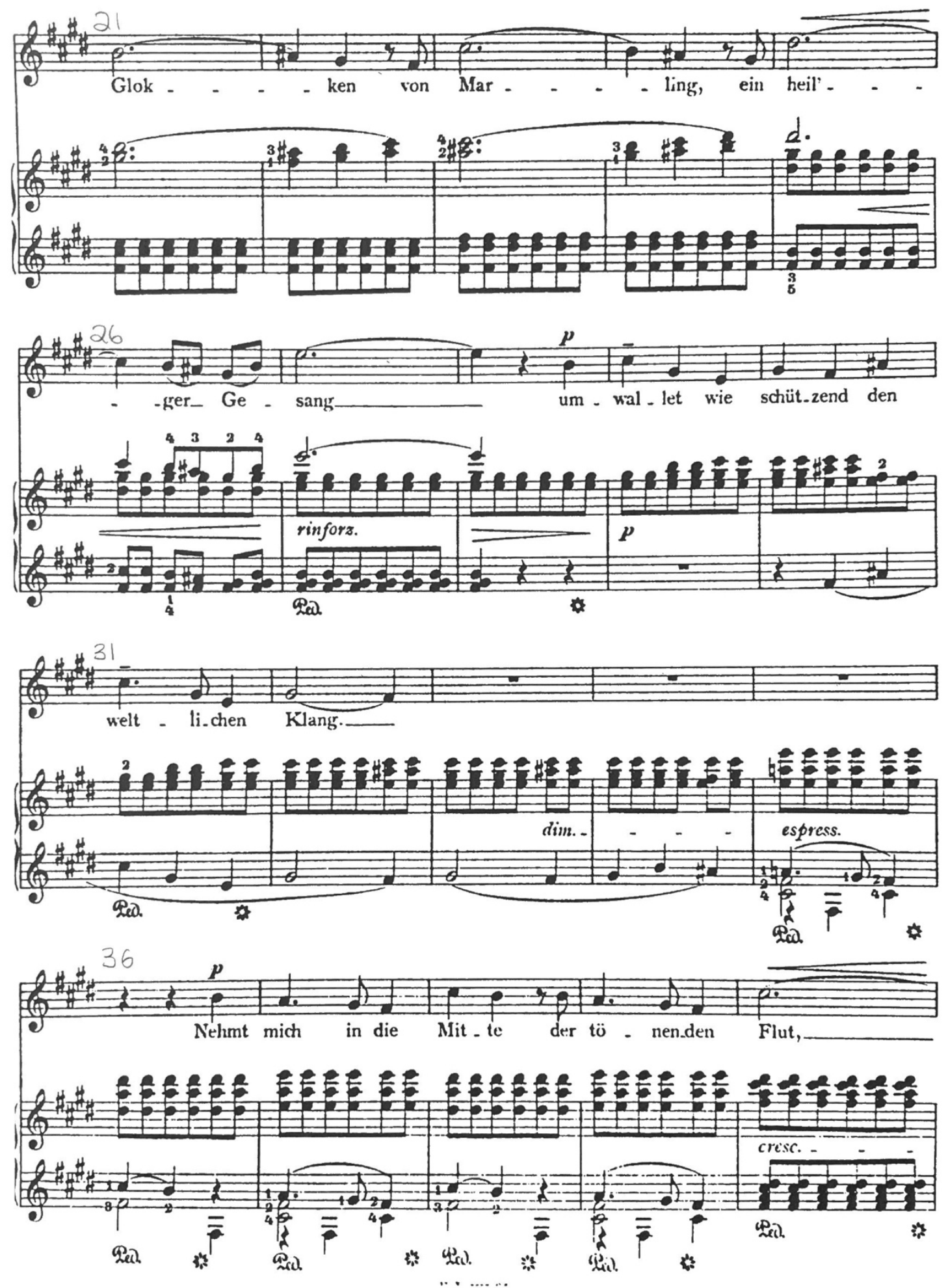

${ }^{113}$ Liszt, Musikalische Werke. 
Example 4.2, continued. Liszt, "Ihr Glocken von Marling” mm. 41-66. ${ }^{114}$
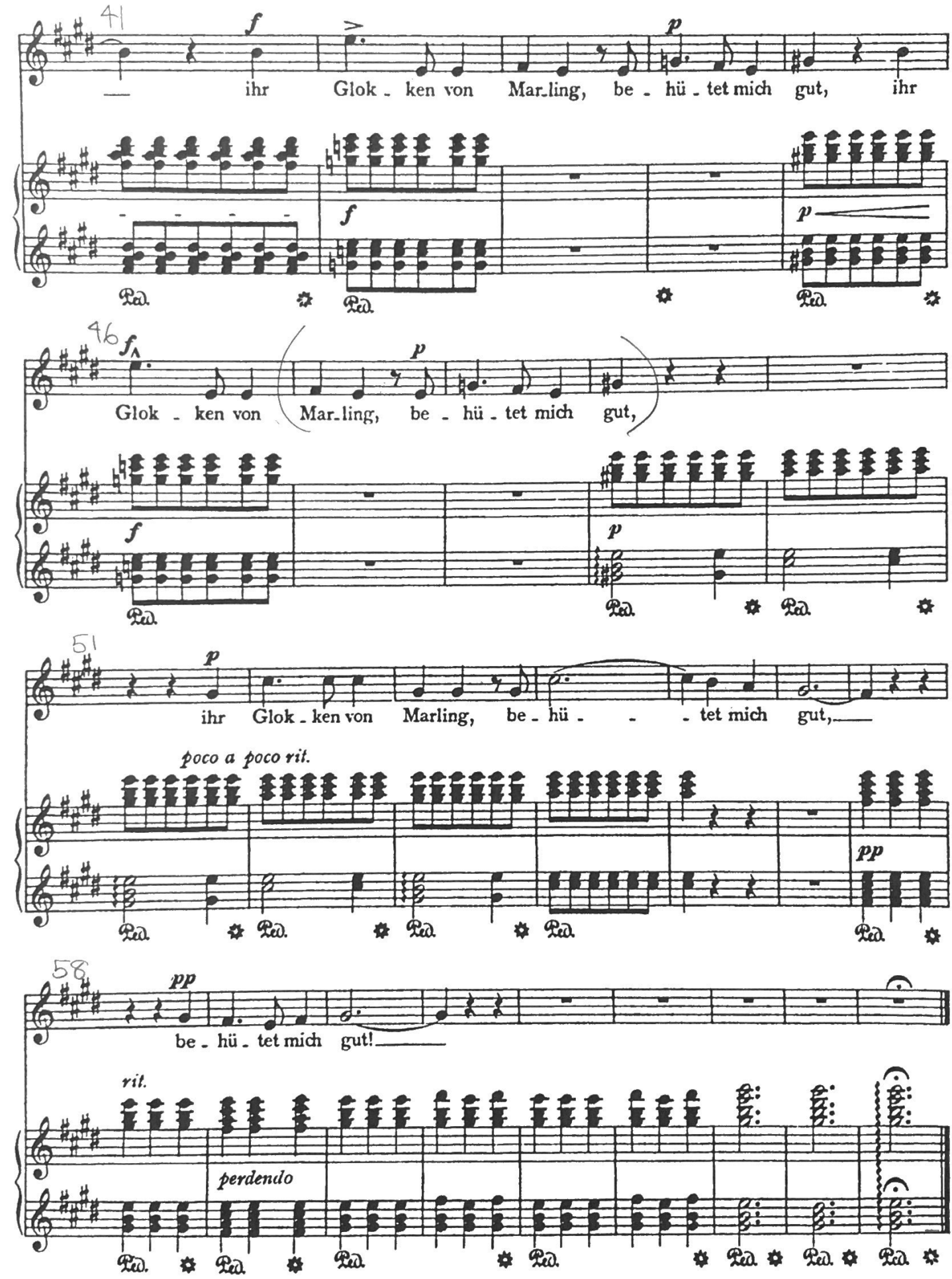

F. L.VII 81 .

${ }^{114}$ Liszt, Franz Liszt:Musikalische Werke. 


\section{Example 4.3. Liszt, "Verlassen" (Gustav Michell)}

Mir ist die Welt so Freudenleer, So kalt als sollte nimmermehr

Die Sonne wieder scheinen;

Seit ich sein Auge nicht mehr seh', Ist mi rim Herzen gar zu weh, Ich weine, ach, muß weinen.

Weiß nicht, was ihn zum Wandern trieb

Weiß nur, daß ich verlassen blieb

Zum Trauern und zum Leiden;

Weiß nur, daß ich bis an das Grab

Ihn ewig lieb im Herzen hab',

Ich weine, ach, muß weinen.

Un wenn die sonn' im Morgen steigt,

Und wenn der Tag zum Schlummer neigt,

Zum Himmel will ich weinen,

$\mathrm{Daß}$ er mir einst ihn wiedergibt,

Der mir das Herz so schwer betrübt,

Ich weine, ach, muß weinen.

In "Verlassen", we get a taste of some of the darker moods Liszt adopts in his poetry

choices. In the text, the maiden speaks of being joyless, and abandoned by her lover. ${ }^{115}$ In her coldness, and solitude she weeps in her loss of him. Liszt uses this poem to take advantage again of his use of silence in the music of "Verlassen" in Example 4.4. In this example, Liszt goes even further to embrace the silence that he was keen to create in his late songs. He uses it in a strategic way. Each time the singer sings of weeping at the end of each stanza there is no accompaniment underneath. These moments take place in mm.18-19, 33-34, and 49. It happens again at measure 40. This time the singer is weeping to the heavens. All the instances where the singer is weeping, Liszt leaves the accompaniment out to further create the depressing image of

\footnotetext{
${ }^{115}$ For full translation see, Emily Enzust, "The liederNet Archive: Texts, and Translations to Lieder, Mélodies, Art Songs, Choral Pieces, and Other Vocal Music,” http://www.lieder.net/.
} 
her being alone in her grief. This is not Liszt's only display of text painting. In each stanza of the poem, Liszt changes the texture of the piano to match what the singer is saying. In the first stanza in the text is more meditative, and the singer is feeling the coldness of her loneliness. To mirror this, Liszt only has music in the left hand of the piano. This creates a very solemn and somber mood. In the second stanza in, the singer sings of her confusion and frustration after losing her love. The piano adds the right hand back in and is given the expression mark, un poco agitato. The third stanza in contains the most hope out of the entire poem. Here this singer sings of the sun rising in the morning and having hope that the Heavens will one day return her love to her again. Where Liszt has been using pulsing eighth notes in the accompaniment, he now switches to whole and half notes being sustained under the singer. This could represent the eternity of heaven or her waiting for her love to come back. 


\section{Example 4.4 Liszt, "Verlassen," mm.1-15. ${ }^{116}$}

\section{Verlassen}

Lied aus dem Schauspiele "Irrwege" von Gustav Michell.

Franz Liszt.
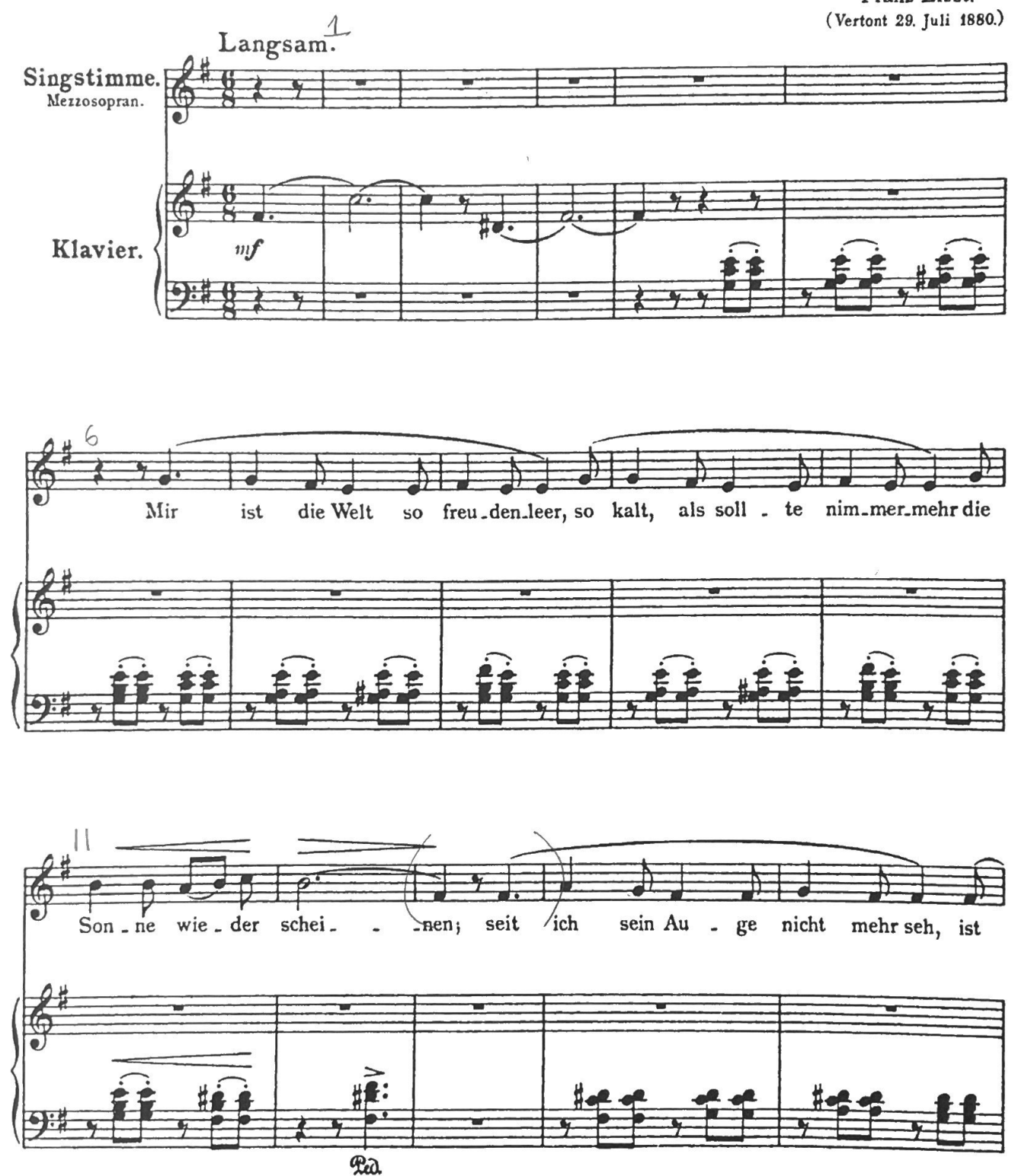

F. L.VII 94.

116 Liszt, Franz Liszt: Musikalische Werke. 
Example 4.4, continued. Liszt, "Verlassen," mm.16-34. ${ }^{117}$
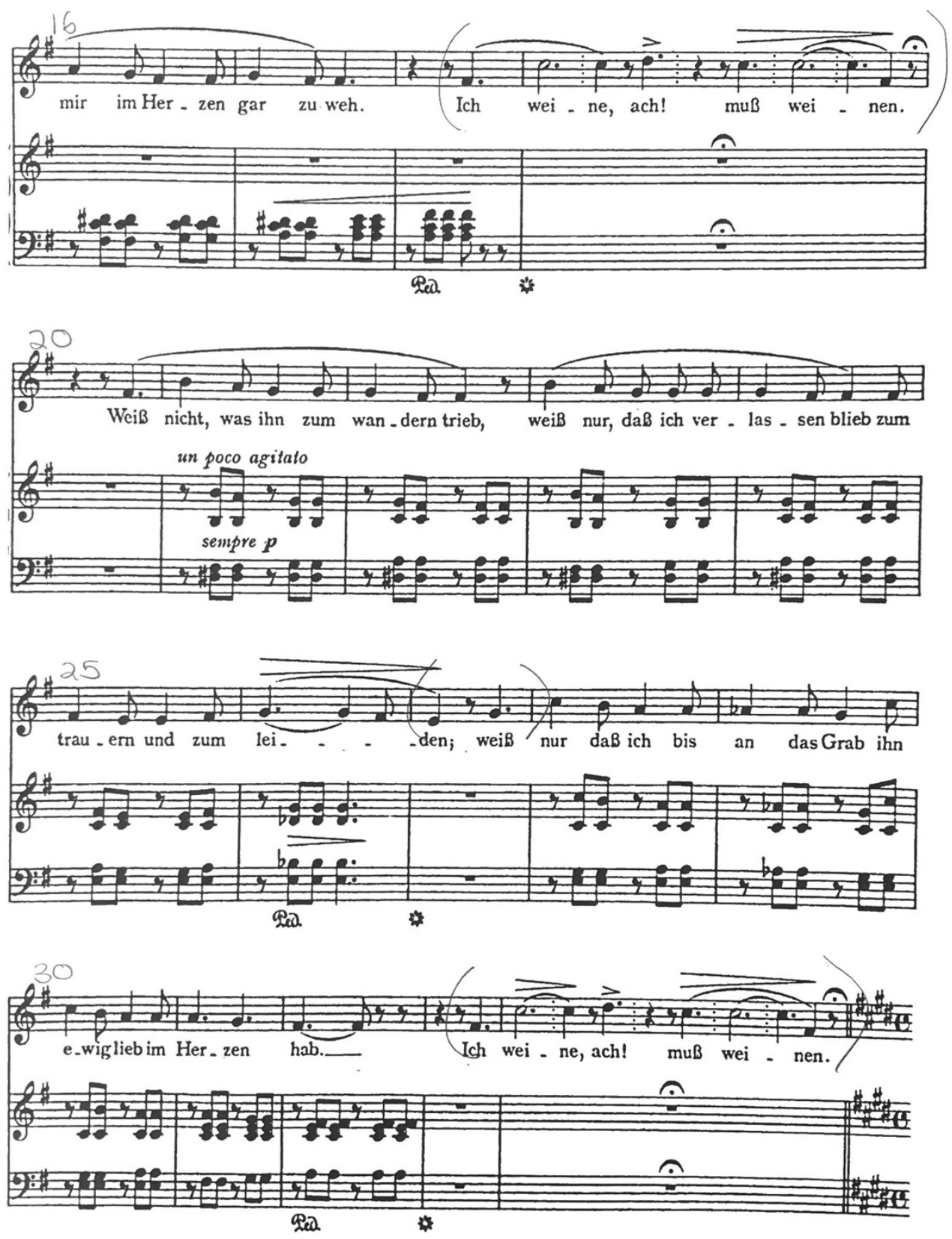

${ }^{117}$ Liszt.Franz Liszt: Musikalische Werke. 
Example 4.4, continued. Liszt, "Verlassen," mm.35-54. ${ }^{118}$
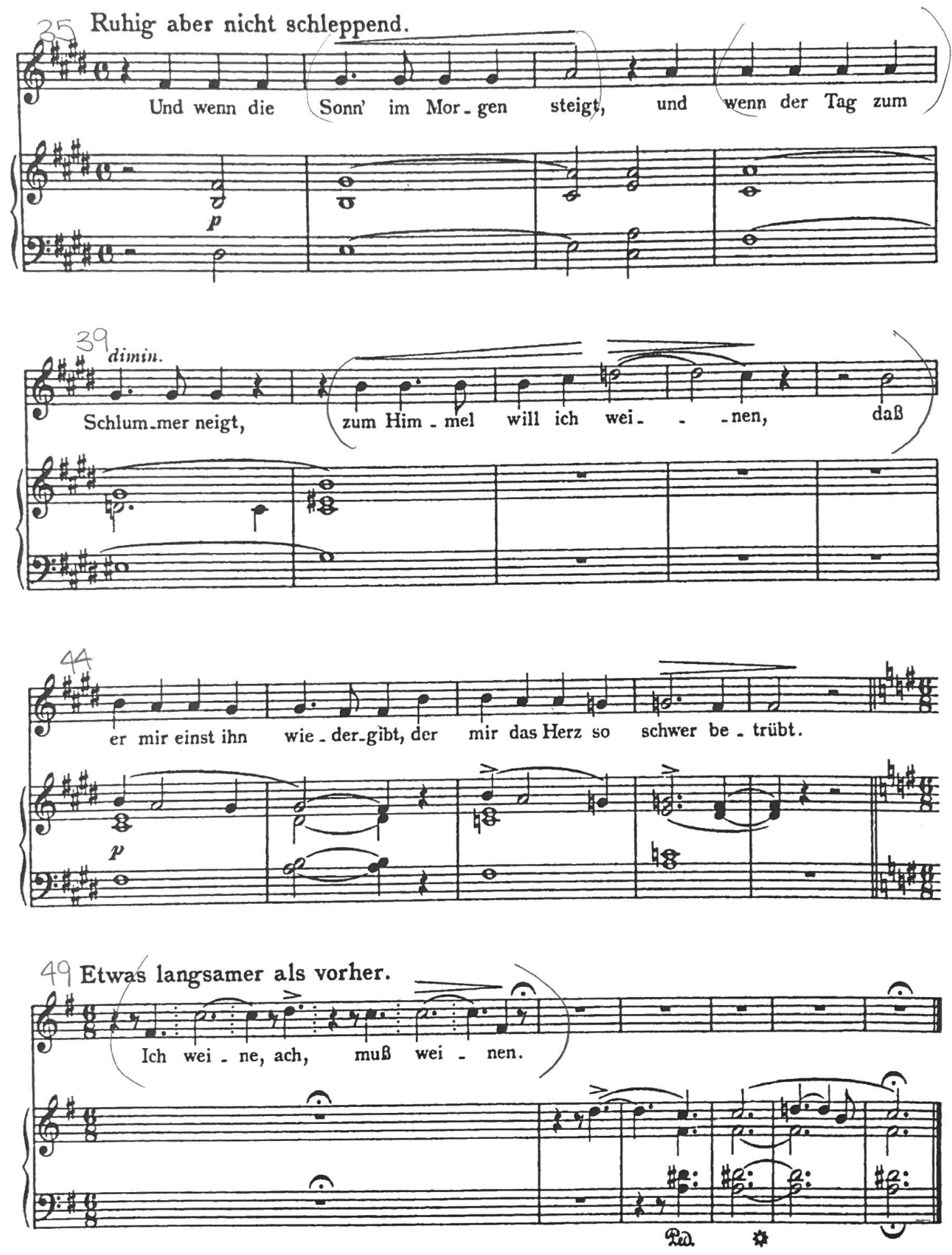

F. L. va 94 .

${ }^{118}$ Liszt, Franz Liszt: Musikalische Werke. 


\section{A brief look at Hugo Wolf's mature song style}

Like Brahms, it is harder to find literature that goes in depth on the late style of Hugo Wolf (1860-1903). The reason behind this could be attributed to the fact that he lived only to be 43 years of age. On top of that, Wolf's creative period was possibly the shortest and most sporadic known to music history.

\section{Example 4.5 Timeline of Hugo Wolf's creative output. ${ }^{119}$}

\begin{tabular}{|l|l|}
\hline Dates & Events \\
\hline $1888-1891$ & $\begin{array}{l}\text { Wolf composed over 200 songs using the poems of Mörike, Eichendorff, } \\
\text { Goethe, Geibel, Keller, and Heyse. }\end{array}$ \\
\hline $1892-1894$ & Silence \\
\hline $1895-1897$ & $\begin{array}{l}\text { He composed an opera (Der Corregidor), around thirty more songs, and an } \\
\text { unfinished opera (Manuel Venegas). }\end{array}$ \\
\hline $1897-1903$ & Madness- death \\
\hline
\end{tabular}

Even in this short span of time his reputation is secured, and he became known as one of the most innovative composers of the nineteenth-century Lied. He is often considered to be the "Wagner of the Lied" as Carol Kimball puts it. ${ }^{120}$ This was mainly due to the fact that he admired the musical techniques of Wagner and as able to incorporate them into the way he composed his art songs. In his songs, his goal was to bring the poem and music together in a complete way, which was similar to Wagner's treatment of operas. Wolf's reputation rests entirely on his songs even though his songs are praised more than they are performed.

When it came to subject matter within his poem choices, Wolf had a wide variety subjects that included; nature, love, religion, war, and the struggles of life. However, all of his

\footnotetext{
119 Eric. Sams, The Songs of Hugo Wolf, 1st Midland ed. (London: Methuen and Co LTD, 1961), 1.

${ }^{120}$ Kimball, Song: A Guide to Art Song, 111.
} 
choices were portrayed in a light of Realism. The texts he chose regardless of subject matter was more realistic than romantic or fanciful.

Wolf's mature works (which we could view now as his late) contain displays of merging traditional and modern elements. As a composer that was so devoted to the poetry, Wolf's implementation of melodic, rhythmic, and harmonic ideas is were usually associated with the poem. This was a distinctive feature that became solidified in his mature songs. The rise and fall of the melody line, it's rhythm, and declamation all stem from the poem that he was setting it to. The voice and the piano can contain separate material, but still be essential to one another for completeness. He embraced blurring the lines of tonality, and his harmonic development often created the tension in the poetry. Susan Youens explains that in "Wire haben beide lange Weit geschwiegen," Wolf's exploration of extended tonality represents the tension between the lovers in the poem. ${ }^{121}$ In his rhythmic development, he would create motives to represent themes or moods within the poetry. In "Auf einer wanderrung," he uses lilting dotted rhythms which he often used to represent the outdoors or a mood of nature.

The formal structure of his songs was more explorative and experimental than Brahms. He was interested in folk music, but he ventured into many different forms to adapt and create his own. He was also very specific in how he gave directions to singers in his Lieder. In his accompaniment, he would associate the way that he manipulated the texture and register of the accompaniment with the mood of the poem. For example, he would set certain songs with the piano centered in a very high register with different levels of textual density gradually shaping the music.

\footnotetext{
${ }^{121}$ Eric Sams and Susan Youens, "Hugo Wolf," Grove Music Online, https://doi.org/10.1093/gmo/9781561592630.article.52073.
} 
At the end of Hugo Wolf's life, he started to suffer mentally. His inspiration would falter, come back and falter again. In the years leading up to his death, he was obsessed with trying to conquer larger forms in an attempt to achieve success in composing operas. After 1899, Wolf was unable to compose music of any kind. He spent some time in an asylum where he died on February 22, 1903.

\section{Wolf's Mature Songs and their Texts}

The following examples of Wolf's mature (what we know now as late) songs and their poems display some of Wolf's traits for text setting, tonality and text painting. In Example 6, in the song "In dem Schatten meiner Locken," the narrative is spoken from the perspective of a maiden pondering whether to wake her love who has fallen asleep beneath the locks of her hair. ${ }^{122}$ Throughout the song, she is contemplating waking him while recalling in a teasing manner his nagging nature. There is an element of sexuality that is implemented in a subtle way in the text. Wolf was known to pick poems that had undertones of sexuality and lust. We see this in the poem where the maiden talks about her lover pining for her and the description of her disheveled hair is supposed to be an indicator that the two of them have been intimate. As the singer recounts her excited and yet reflective soliloquy, Wolf implements his mastery of excellent text declamation and text painting to bring the song to life. Wolf takes this simple text and expands every minute element of it musically. His excellent declamation comes into play as he sets the text within the natural stresses of the language.

\footnotetext{
${ }^{122}$ For full translations see, Eric Sams, The Solo Song of Hugo Wolf, 176.
} 


\section{Example 4.6 Wolf, "In dem Schatten meiner locken," (Anonymous, trans. Paul Heyse)}

In dem schatten meiner locken

Schief mir mein geliebter ein.

Weck' ich ihn nun auf?-Ach nein!

Sorglich strählt' ich meine krausen

Locken tälich in der frühe,

Doch unsonat ist meine Mühe,

Weil die winde sie zerzausen.

Lockenschatten, windessausen

Schläferten den Liebsten ein.

Weck' ich ihn nun auf?-Ach nein!

Hören muß ich, wie ihn gräme,

$\mathrm{Da}$ er schmachtet schon so lange,

Daß ihm leben [geb' und nehme]

Diese meine braune wange,

Und er nennt mich seine Schlange,

Und doch schlief er bei mir ein.

Weck' ich ihn nun auf/--Ach nein!

In Example 4.7, you have the score of "Im dem Schatten meiner locken". One excellent example of his declamation is how he sets the phrase "Weck ich ihn nun auf? Ach nein!". This is where the singer asks whether or not she should wake her lover up and says no. Wolf's love for opera shines through in the recitative way he sets the question. ${ }^{123} \mathrm{He}$ also sets the text musically to mimic the inflection the voice has when you ask a question. In Example 4.7, you can see the first time the singer asks this question in measure 6 . As the singer is asking the question, the melody line goes up. When she answers the question, the melody goes down in measure 10 . He has the singer do this each time she asks the question placing only a single chord under to not draw attention away from the recitative moment. The music in the accompaniment between mm.

\footnotetext{
123 "Musical Analysis: Wolf's 'In Dem Schatten Meiner Locken,'” accessed March 5, 2019,
} https://poptug.com/musical-analysis-wolfs-in-dem-schatten-meiner-locken/. 
7-9, and act almost like her mind thinking and trying to decide. This same scene plays out from mm.28-31, and gain in mm. 49-53. It is also important to note how he changes the dynamic of each of these questions throughout the song. In the first question, the dynamic is set at "pp" as if she is trying to be very quiet while she decides whether or not to wake him. In the second stanza, the dynamic is now at "p" when she asks the question and then moves back to "pp" when she decides not to. This could represent her actually getting ready to wake him this time, and then changing her mind. In the third stanza the question and answer is back at "pp" to indicate her resolve in letting him sleep.

Like Lizst did in "Verlassen" Wolf changes the piano texture in each stanza to mirror the action of the poem. In the first and shortest stanza, the singer is setting the scene. The melody is simple and long, and in turn the piano part is light and supportive of the voice. It starts at "p" to indicate that she is trying to be quiet and not wake him. In the second stanza, she distresses over how no matter how much attention she spends on her hair it always gets disheveled. The piano begins with the same material, but expands, thickens and becomes more animated. The vocal line begins in a higher register at "f" and her phrases become shorter to create more of an image of panic or anxiety. After all the excitement of her expression the piano changes register, and the dynamic goes down to "pp" to represent her love being lulled back to sleep. The third stanza starts in the same frenzied mood that the second started with the rhythmic activity and chromaticism heightened in the piano as she speaks of listening to him complain and pine after her. It is also important to note that Wolf is constantly changing key centers throughout the song, perhaps to mirror how the singer is bouncing back and forth between different thoughts in her narrative. As we've discussed before, his rich harmonic pallete is also at time tide to the text and not just for experimentation. 
Example 4.7 Wolf, “In dem Schatten meiner Locken,” mm.1-15. ${ }^{124}$

\section{Wolf}

In dem Schatten meiner Locken

(Anon., trans. Heyse)
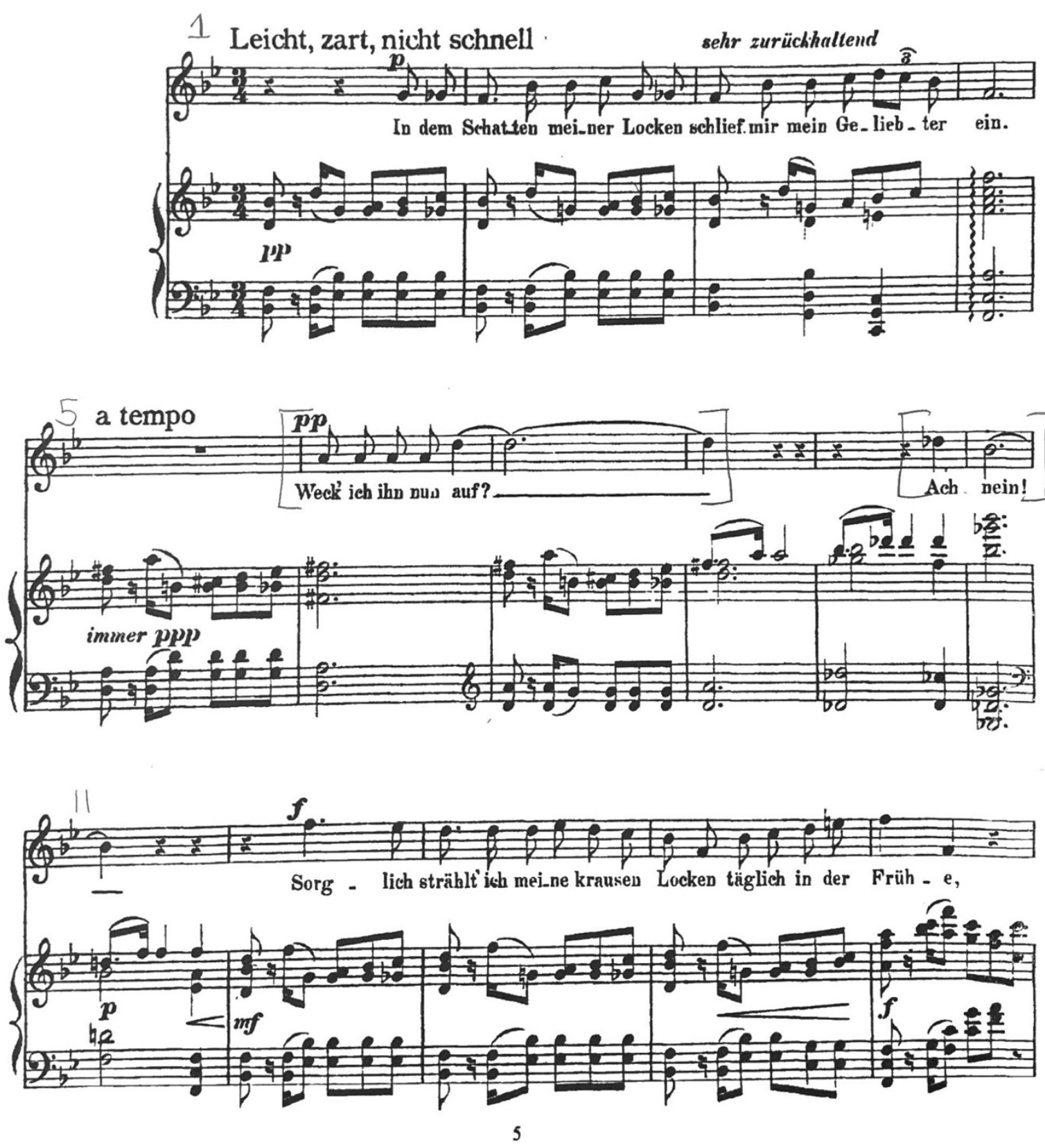

${ }^{124}$ Hugo Wolf, Spanisches Liederbuch (Mainz: Schott Music, 1891), 5. 
Example 4.7, continued. Wolf, “In dem Schatten meiner locken" mm.16-37. ${ }^{125}$
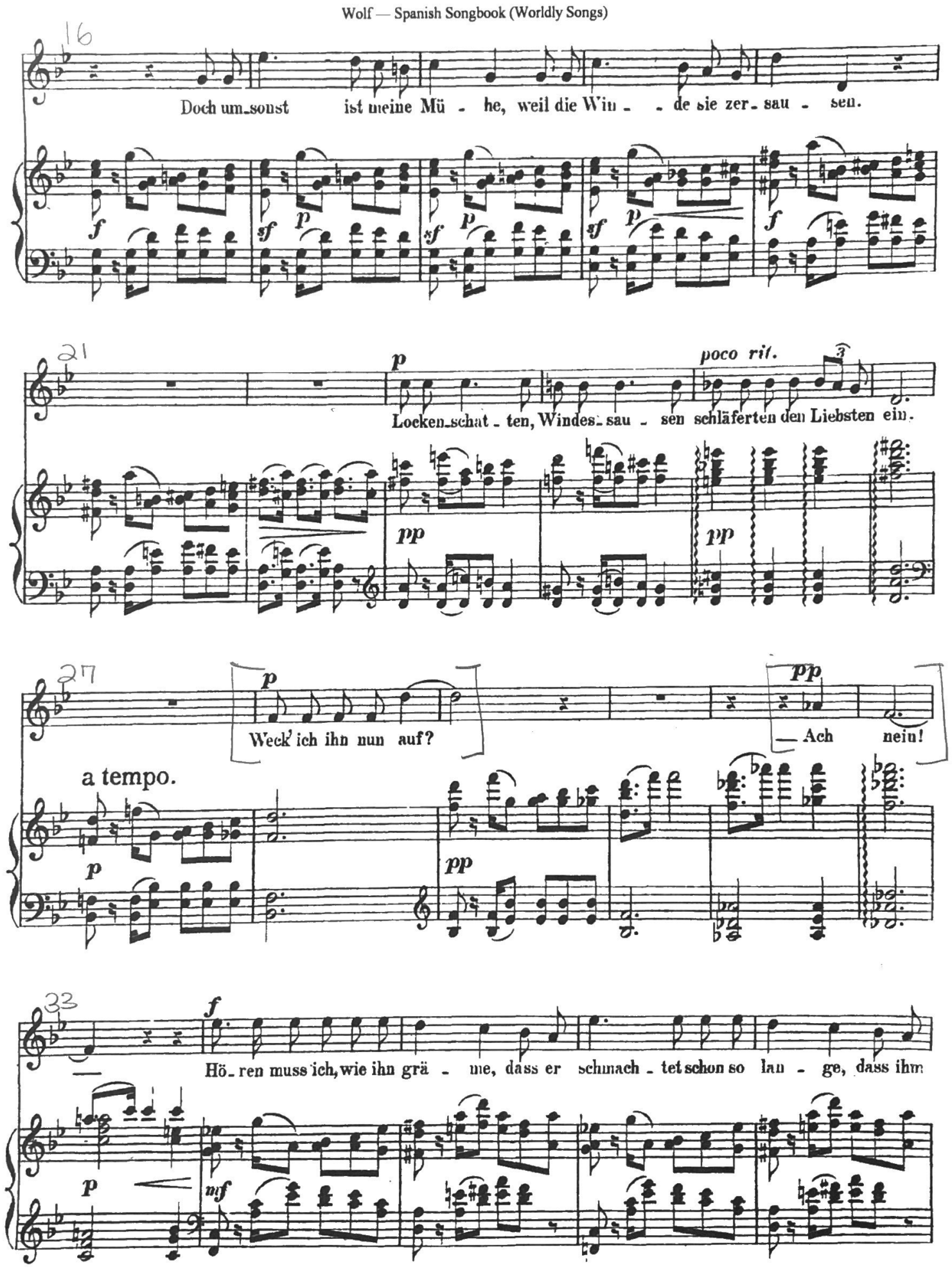

${ }^{125}$ Wolf, Spanisches Liederbuch, 6. 
Example 4.7, continued. Wolf, “In dem Schatten meiner locken" mm. 38-58. ${ }^{126}$
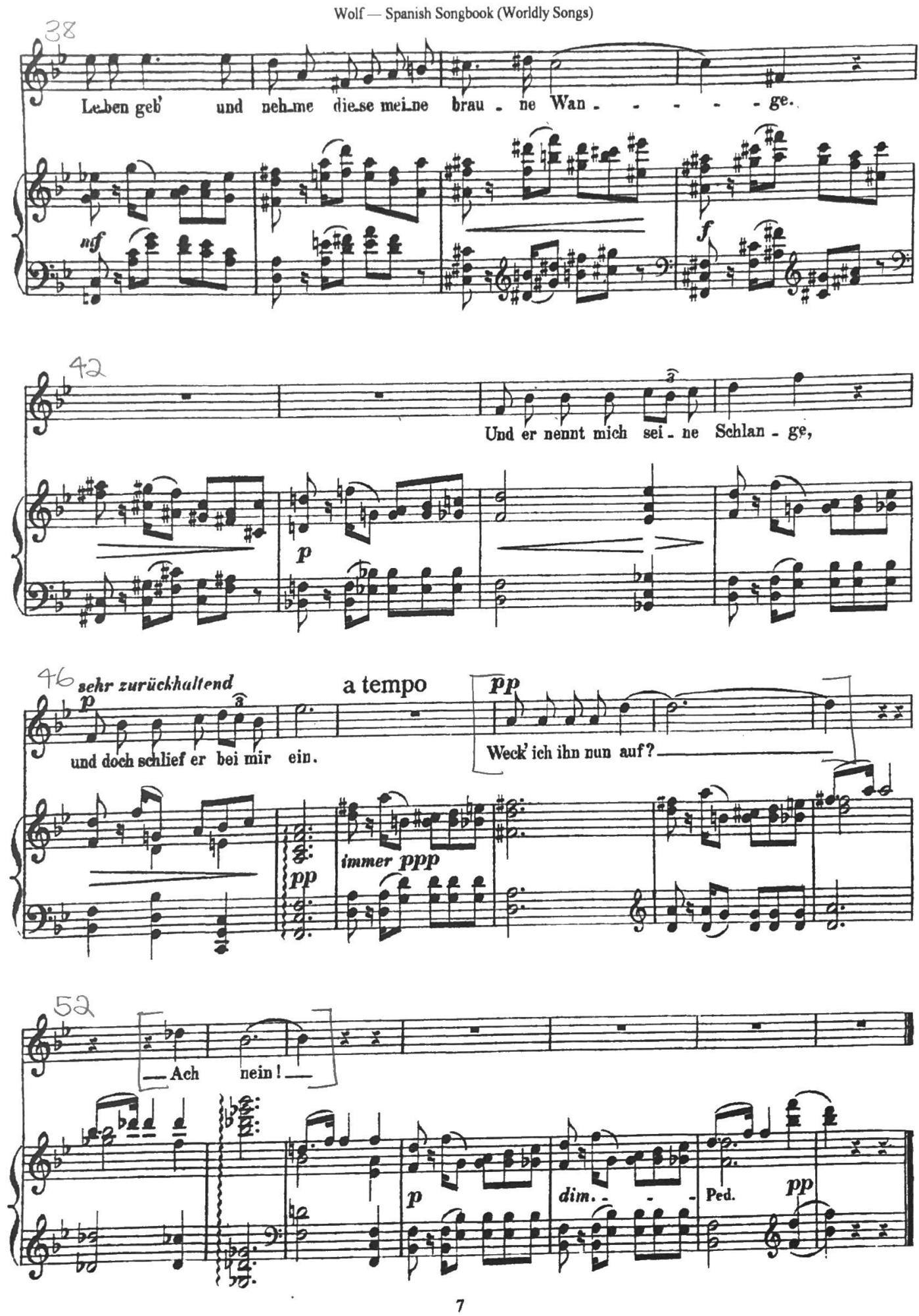

${ }^{126}$ Wolf, Spanisches Liederbuch, 7. 
"Alles endet, was entstehet" is the second song of Wolf"s last set, Michelangelo-Lieder. As it has been stated, these songs are not seen as holding the same mastery as his Italian Songbook. However, when compared to Brahms's Vier ernste Gesänge, one cannot help but see the similarities. The text has a very carries a very dark message about life and death. It speaks about all created things coming to an end in same way that the first three songs of Vier ernste Gesänge does. ${ }^{127}$ Since Wolf was not yet old in age, it is a curious that he set this song about death and decay.

\section{Example 4.8 Wolf, "Alles endet, was entstehet" (Michelangelo, trans. Walter Heinrich Robert-Tornow)}

Alles endet, was entstehet. Alles, alles rings vergehet, Den die zeit flieht, und die sonne Sieht, daß alles rings vergehet, Denken, reden, schmerz, und wonne; Und die wir zur enkeln hatten Schwanden wie bei tag die schatten, Wie ein dunst im windeshauch. Menschen waren wir ja auch, Froh und traurig, so wie ihr, Und nun sind wir leblos hier, Sind nur erde, wie ihr sheet. Alles ended, was entstehet. Alles, alles rings vergehet.

If you look at Example 4.9, you see the first page of "Alles endet, was enstehet." The dark octaves present the same brooding mood that we get in "Denn es gehet." Eric Sams explains that the entire song seems devoid of life in the melody and the accompaniment, which is probably what Wolf was trying to convey. ${ }^{128}$ The song starts off lifeless, and slowly begins to

\footnotetext{
${ }^{127}$ For a full translation of the text see, Sams, The Songs of Hugo Wolf, 269.

${ }^{128}$ Sams, The Songs of Hugo Wolf,
} 
show sparks of life as the song progresses. However, in the end the warmth dies away again as the singer states again "Alles, Alles ring vergehet." Most scholars agree that this song is strange and terrifying when compared to his others works. His style and devices are present, but the mood is much different than what we've seen of Wolf. Was this the start of a new phase is Wolf's style that might of come to be known as his late style? 
Example 4.9 Wolf, “Alles endet, was entstehet," mm. 1-14. ${ }^{129}$

Wolf

Alles endet, was entstehet

(Michelangelo, trans. Berhhoff)
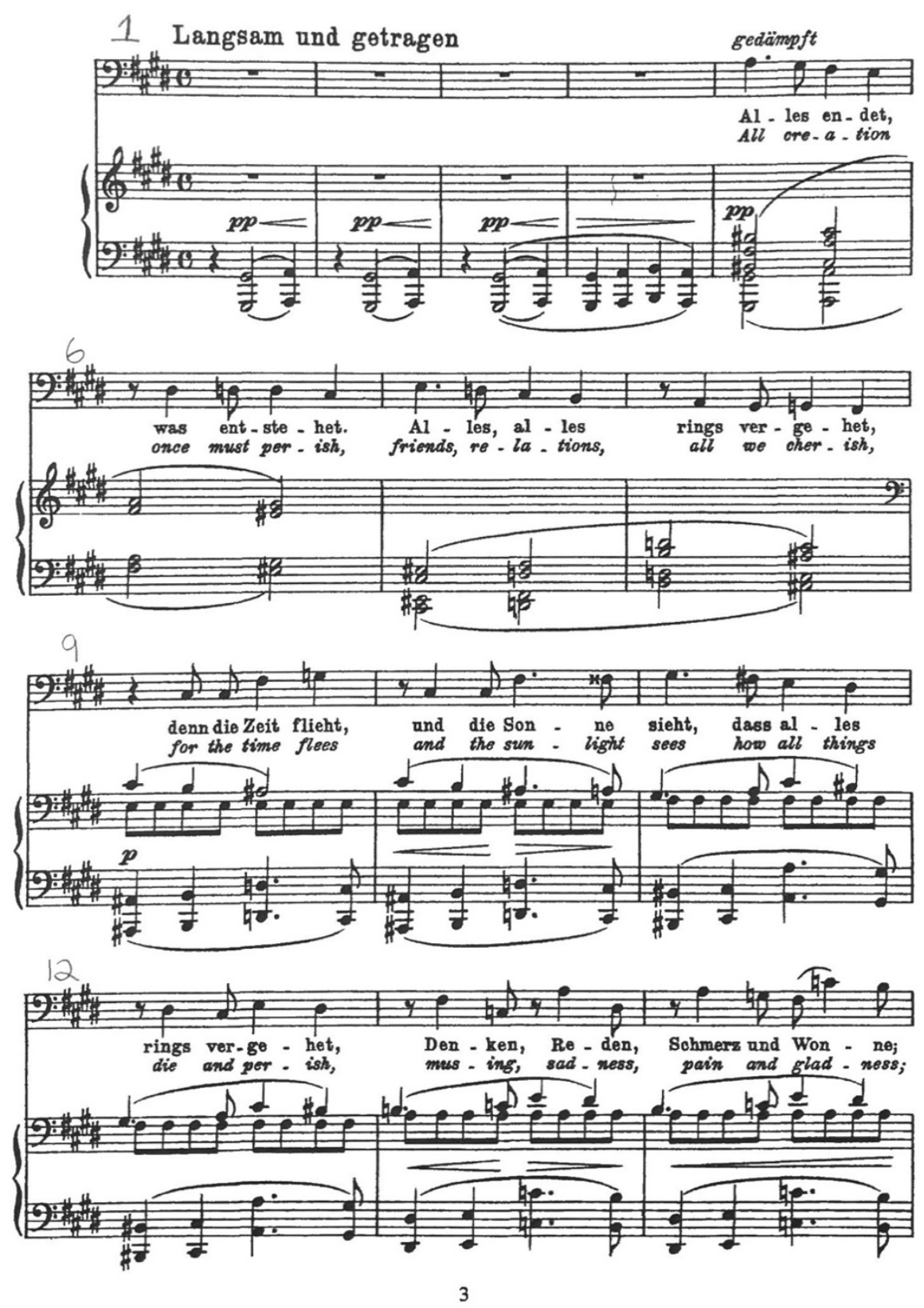

${ }^{129}$ Hugo Wolf, Michelangelo-Lieder, (Leipsig: C.F. Peters, 1908), 3. 


\section{Comparing Brahms to his contemporaries}

Looking back at these nineteenth-century trends and composers, there are many threads that weave in and out of each other. It is clear that all of them were affected by the $19^{\text {th }}$ Century in some way. However, they each took hold of the $19^{\text {th }}$ Century and incorporated it into their music in their own ways. They all shared similar literary choices in subject matter, and in the poets that they chose. However, they each chose their subjects and poets to suit very different reasons. Brahms chose his text for music inspiration, Wolf chose his text based on quality, Liszt chose the text that spoke to the emotion of his heart. Where Wolf, and Liszt fully embraced the trends of the time and evolved as those trends did, Brahms took bits and pieces of the them, but still held true to the traditions of the past centuries. Where Wolf chose to uphold the integrity of the poem within his songs, Brahms chose to manipulate and use the poem to fit his inspiration. If we compare Brahms with Wolf, perhaps we could look at Wolf being born later than Brahms as a possible reason for why he embraced breaking the barriers of tonality more than Brahms did. However, if we compare Brahms's with Liszt, who was born 22 years earlier than Brahms it would seem that Liszt would have more reason to hold to tradition of the past. However, he too pushed the bounds of tonality until he was at the door of impressionism. To know the exact reason for why they made the choices that they did, we would have to ask them. What we do know are possible influences that nurtured and developed the way they chose to allow their styles to be molded by the nineteenth-century. Nationality, family, background, training, life, love, loss, and death molded them all in different and similar ways and yielded different and equally important styles. 


\section{Chapter 5}

\section{Conclusion: Reconsidering Brahms's Late Style}

With age and experience came not only greater ambition but also greater expectations. And so their self-fashioning of their late persona was in part conditioned by their worries, different as they were, about their final artistic legacy. ${ }^{130}$

As we have seen in the previous chapters, Brahms's late style was a culmination of his early and mature periods refined by life, growth, and experience. Unlike Beethoven, Liszt and other similar composers, Brahms's style did not change drastically in his late years. In chapter 2, we saw that his interest in texts dealing with contemplation of life, loss, and death grew in his later years. Although many scholars felt that his change of subject preference in his late years, possibly pointed to an adoption of pessimistic views toward life and death, we saw evidence that that wasn't necessarily true. Brahms did not completely give over to darkness of mortality in his last years but allowed the thoughts and feelings to flow freely in and out of his creative process. He was aware of the inevitable, but he did not let it consume his creative output in his last years.

In chapter 3, we discovered that a lot of his stylistic traits that he established in his youth were maintained in his late years. In some cases, he refined and tighten certain features in a more organized way, and in some cases his employment of certain musical features mirrored that of his youth. Chapter 4 showed us where Brahms's stood in the nineteenth century when compared to some of his contemporaries. Wolf and Liszt both allowed their creative style to change with the more modern trends that were spreading from the mid-nineteenth century forward. Brahms's style on the other hand was still trying to breathe new life into tradition. More important we see a significant piece of evidence when it comes to how some late style views are tied to age. Wolf

\footnotetext{
${ }^{130}$ Linda Hutcheon, Michael Hutcheon, Four Last Songs : Aging and Creativity in Verdi, Strauss, Messiaen, and Britten, 2015, 108.
} 
lived a much shorter life than Brahms, and surpassed him in experimentation and expansion of his style. This may have more to do with the fact that Wolf was born later in the nineteenth century and may not have had as close of a connection to the tradition of the past as Brahms and Liszt. However, as it was pointed out in the previous chapter, Liszt was born earlier than Brahms, and yet he too surpassed him in experimentation and expansion. This could be a circumstance of his many travels around Europe and adoption of different techniques. In the end, the most important thing it shows us is that what a composer chooses to adopt in their late style is not necessarily tide to how long they live. Let's now take a look at what this study contributes to the notions of late style.

\section{Challenging the notions of late style in general and as it pertains to Brahms}

As it was said in chapter 1, there are many mixed views when it comes to the concept of late style. Some scholars such as Edward Said see the late style as a period where the effects of aging automatically pull the artist into a new realm that could be negative or positive. ${ }^{131}$ Others like Theodore Adorno have seen it as a period of rebellion, and roughness as he did in his study of Beethoven. ${ }^{132}$ The issue that we can run into is where our personal views of the concept of late style or of what a late style should be, get in the way of us experiencing and appreciating it the way it is. The Hutcheons lay out many arguments in regard to this very issue. ${ }^{133}$ One of the points that that they explain is how we all construct narratives for what we want our lives to be. Our goal in the end of this construction is a legacy that we can leave behind when we are gone. As we get older, this narrative can grow, evolve or completely change depending on our personal

\footnotetext{
${ }^{131}$ Edward W. Said, Music at the Limits (New York: Columbia University Press, 2008), 6.

132 Said, Music at the Limits, 302.

${ }^{133}$ Hutcheon and Hutcheon, Four Last Songs, ch 7.
} 
and professional life experiences. An artist can lose or stop their creativity due to failing health, or because they no longer need the financial support it provides. An artist can also continue, increase, or evolve their creative output due to thoughts of mortality, going deaf or blind, or for financial needs. The point that Hutcheon is constantly making is that every narrative is completely different and yields a completely different legacy. Where illness can cripple some artists, it can became fuel to others. Where others ended or slowed their creative output because they didn't need the financial support, others increased theirs because they did.

The defining moment in a person's narrative and what shows you the most about a person is how their narrative changes when pressure from the world comes against them. What does an artist do when the narrative that they have created for themselves comes up against the expectations of their admirers or critics? They undergo, what Elliott Jaques coined in 1965 as a "Late-life crisis." ${ }^{34}$ As an artist gets older, they start to perceive the changing times and assess how they can continue to stay relevant. At the same time, their audiences begin to expect greater, and final staples of their creativity. They are expected to deliver to their audiences culminating and advanced works that will forever solidify their place in their medium. How does an artist combat this pressure when the narrative that they have created for themselves goes in a completely different direction? In most cases if they do not follow this narrative, they are dismissed as an artist that is past their prime. Here is where one of the main issues with the late style concept arises. In Brahms, we saw an artist who decided to hold true to the narrative that he created for his life. In spite of criticism from his contemporaries, and the public, he chose not to alter his narrative to stay relevant in the changing time. This does not mean that those who decided to change their narrative were more weak or impressionable. Who's to say that the

${ }^{134}$ Hutcheon and Hutcheon, Four Last Songs, 102. 
change or evolutions wasn't already part of the narrative? Some artists from the beginning are constantly looking to stretch the limits and move their medium forward. The point of the entire late style concept is that each one is unique. The challenges and changes of aging are different for each individual composer which makes it impossible to make generalizing about what a late style should look like. In their study of the late works of Verdi, Strauss, Messiaen, and Britten, the Hutcheons discovered that these composers all maintained the creativity of their late years in their own individual ways, and, in the end, their final works were a result of their different life experiences and circumstances. ${ }^{135}$

The most important point to take from this study is that the concept of late style cannot and should not be used to make generalizations of what an artist's final works or period should produce. Although it may be easier to put people and things in boxes where we can easily identify them and categorize them, you will never see the truth of them this way. When you come to any type of analysis of study with boxes instead of an open mind, you are immediately hindering you own growth and understanding.

\section{Benefits of this type of analysis for scholars and performer}

The late style concept and analysis is a great and even vital concept that all scholars will tap into at moments in their scholarly research. Any time we look into the biographical information and the works of a composer's life, we are tapping into a study the style period that that piece came from. However, a late style analysis sheds a different light, because a composers last works can show you a lot about how they viewed their own narrative and place in the world. Did they hold onto the foundation of their traditions, push the boundaries into new trends, or

${ }^{135}$ Hutcheon and Hutcheon, Four Last Songs, 105-108. 
combine the two? Knowing this about a composer can also tell one how they may have affected other composers, their students, and society in the time that followed. One can see a composer's autobiography of creativity within their late works, regardless of whether their style changed a lot, a little, or none at all. Knowing where a composer's journey ended can say a lot about the journey itself. As scholars, it is always important to know the backdrop of a piece of music. Knowing the circumstances that a piece was birthed out of gives you a deeper understanding of it. When we look into the personal, professional, social, and mental circumstances that produced a piece of art, we ourselves learn all the different ways that these circumstances that effect one's creative output. In this study, especially, we have learned that the outcome can be vastly different even if multiple artists undergo similar circumstances in their lives. Learning how to put this type of analysis to practice will aid us continually throughout our professional careers. If we are familiar with a composer and come across a song that contrasts to their other works for some reason, we now have steps we can take to try and understand why this particular piece stands out from the rest of their output

As a performer, it is very important that you know the context of the piece that you are performing so that in your interpretation of it, (even if you want to take creative liberties) you can bring the performance of the piece as close as possible to how the composer intended it to be performed. For example, we might say that someone is preparing to perform one of Brahms's late folk songs. When the performer looks at it and sees that it is devoid of expression marks for the singer (which Brahms was known to do in his late song setting) they could take that as an indicator that they should be rather even and mellow throughout the song. One would hope that they would be creative and make their own expressions for the song, but it would be good to know that Brahms left the expression marks out for the singer to be as creative as they wanted to. 
If you were giving a recital that had early and late works of a single composer, it would be good to know what was going on during the two different periods that those works were composed in. It may or may not make a difference in how you perform them, but at least you will have that much more confidence in knowing that you are doing them justice.

The main issue there seems to be right now, that still needs clarification is how we label and define late style. Some scholars view the late style as the works composed during a composers old age. However, that leaves out composers such as, Mozart, Schumann, Wolf who died at a relatively young or middle age. Once again this is one of those issues of getting away from the box and allowing room for circumstances that are not so black and white. If we looked at the late style concept as an analysis of a composers last works regardless of age, that opens the conversation up to included everyone regardless of age, or style. As we have seen, a composer having a groundbreaking or monumental late period does not always happen even in those who live long lives. The important thing is approaching each composer with the same amount of consideration regardless of their circumstances. Composers who died young can still have a lot to say in their last works, regardless of how old they were when they composed them.

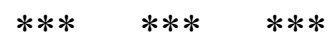

In essence, the late style analysis it is one of the many ways that we connect the dots of our music history knowledge. We can add our late style analysis to what we already know about their contemporaries to help us continue to make connections throughout history. If knowledge were like a puzzle we were trying to put together, a late style analysis would be a technique that we could use to help us put some of the tricky pieces together. It is not the end of the process, but 
it helps us fill in some of the gaps. The gifts and talents within each composer are unique and special because they're the only ones that can create them. No one can step into Brahms's life and have the same outcome in their late years as he did, because their response to his life circumstances would be completely different from his and yield a different result. This is the important thing to remember about any type of analysis. We must remain open to what we are presented regardless of our personal preferences or views. There must be respect of that individuals work and an understanding that their views, differences, and similarities work together to create the history that we now know. 


\section{Bibliography}

Adorno, Theodor W. Beethoven: The Philosophy of Music: Fragments and Texts. Edited by Rolf. Tiedemann. Stanford, Calif.: Stanford University Press, 1998.

Alexander, Bryce. "The Rivalry Between Hugo Wolf and Johannes Brahms." EzineArticles. Accessed February 20, 2019. https://ezinearticles.com/?The-Rivalry-Between-Hugo-Wolf-and-JohannesBrahms\&id $=5427409$.

Arnold, Ben. The Liszt Companion. Westport, CT: Greenwood Press, 2002.

Beard, David, and Kenneth Gloag. Musicology: The Key Concepts, 2016. http://public.eblib.com/choice/publicfullrecord.aspx?p=4355127.

Beller-McKenna, Daniel. "Brahms, the Bible, and Post-Romanticism: Cultural Issues in Johannes Brahms’s Later Settings of Biblical Texts, 1877-1896.” Harvard University, 1994.

-. Brahms and the German Spirit. Cambridge, Mass.: Harvard University Press, 2004. http://www.h-net.org/review/hrev-a0e5z8-aa.

_. 'How 'Deutsch' a Requiem? Absolute Music, Universality, and the Reception of Brahms's 'Ein Deutsches Requiem,' Op. 45.” 19th-Century Music 22, no. 1 (1998): 3-19.

Boylan, Paul Charles. "The Lieder of Hugo Wolf: Zenith of the German Art Song,” 1968.

Bozarth, George S., and Walter Frisch. Brahms, Johannes. Oxford University Press, 2001. http://www.oxfordmusiconline.com/grovemusic/view/10.1093/gmo/9781561592630.001.0001/o mo-9781561592630-e-0000051879.

Brahms, Johannes. 49 Deutsche Volkslieder. First Edition. Berlin: N.Simrock, 1894. https://imslp.org/wiki/49_Deutsche_Volkslieder\%2C_WoO_33_(Brahms\%2C_Johannes).

—. Forty Songs. Edited by James Huneker. Boston,: Oliver Ditson Company, 1903. https://catalog.hathitrust.org/Record/008326029.

—_. Sechs Gesänge :Für Eine Sopran-Oder Tenor-Stimme Mit Begleitung Des Pianoforte : Op. 6. Leipzig: B. Senff, 1853. http://hdl.handle.net/2027/uc1.c034145258.

—. Vier Ernste Gesänge. Edited by Max Friedlaender. Leipzig: Edition Peters, 1920. https://imslp.org/wiki/4_Serious_Songs,_Op.121_(Brahms,_Johannes).

Brahms, Johannes, and Styra. Avins. Johannes Brahms: Life and Letters. Oxford ; Oxford University Press, 1997. http://catdir.loc.gov/catdir/enhancements/fy0725/97005417-b.html. 
Eckhardt, Maria, Rena Charnin Mueller, and Alan Walker. Liszt, Franz. Oxford University Press, 2001.

http://www.oxfordmusiconline.com/grovemusic/view/10.1093/gmo/9781561592630.001.0001/o mo-9781561592630-e-0000048265.

Ezust, Emily. "Bells of Marling (Kuh, Set by Franz Liszt) (The LiederNet Archive: Texts and Translations to Lieder, Mélodies, Canzoni, and Other Classical Vocal Music)." Accessed March 20, 2019. http://www.lieder.net/lieder/get text.html?TextId=9678.

"Mein Herz Ist Schwer, Mein Auge Wacht (Geibel, Set by Johannes Brahms, Anna Stubenberg, Gräfin) (The LiederNet Archive: Texts and Translations to Lieder, Mélodies, Canzoni, and Other Classical Vocal Music)." Accessed February 12, 2019. http://www.lieder.net/lieder/get text.html?TextId=5971.

- "The LiederNet Archive: Texts and Translations to Lieder, Mélodies, Art Songs, Choral Pieces, and Other Vocal Music.” Accessed March 16, 2019. http://www.lieder.net/.

Friedlaender, Max. Brahms's Lieder: An Introduction to the Songs for One and Two Voices. New York: AMS Press, 1976.

Gál, Hans. Johannes Brahms: His Work and Personality. London: Severn House, 1975.

Geiringer, Karl. Brahms, His Life and Work. 2d ed., rev. And enl., with A new appendix of Brahms's letters. Anchor Books ; 248. Garden City, New York: Doubleday, 1961.

Gelbart, Matthew. The Invention of "Folk Music" and "Art Music": Emerging Categories from Ossian to Wagner. Cambridge, UK ; Cambridge University Press, 2007.

Gorrell, Lorraine. The Nineteenth-Century German Lied. Portland, Or.: Amadeus Press, 1993. http://www.h-net.org/review/hrev-a0e3o2-aa.

Hallmark, Rufus E. German Lieder in the Nineteenth Century. Second edition. Routledge Studies in Musical Genres. New York: Routledge, 2010. http://bvbr.bib-

bvb.de:8991/F? func $=$ service \&doc library $=$ BVB01\&doc number $=018007996 \&$ line number $=00$ 01\&func code=DB_RECORDS\&service type=MEDIA.

Hirsch, Marjorie Wing. Romantic Lieder and the Search for Lost Paradise. Cambridge, UK; Cambridge University Press, 2007. http://catdir.loc.gov/catdir/enhancements/fy0834/2008295676-t.html.

“Home: Oxford English Dictionary, s.v. "art(n.),.” Accessed March 18, 2019. http://www.oed.com/.

Horgan, Sally. "The Spirit of Folk Song in the Lieder of Johannes Brahms," n.d., 3. http://www.calstetela.edu/sites/default/files/centers/Wagner/documents/Brahms.pdf 
Hutcheon, Linda, and Michael Hutcheon. Four Last Songs: Aging and Creativity in Verdi, Strauss, Messiaen, and Britten, 2015.

Hutcheon, Michael, and Linda Hutcheon. "Late Style(s): The Ageism of the Singular," Occasion: Interdisciplinary Studies in the Humanities v.4, 2012. http://occasion.stanford.edu/node/93.

Jacobson, Bernard. The Music of Johannes Brahms. London: Tantivy Press ;, 1977. https://baclac.on.worldcat.org/oclc/715459102.

Johnson, Paul. “World English Bible with Deuterocanon.” Accessed March 29, 2019. https://ebible.org/web/.

Kimball, Carol. Song: A Guide to Art Song Style and Literature. Revised Edition. Milwaukee, WI: Hal Leonard Corporation, 2005.

Lau, Wing. “Composing Declamation Notated Meter Changes in Brahms's Lieder." Music Theory Online 21, no. 2 (2015). https://doi.org/10.30535/mto.21.2.6.

Liszt, Franz. Franz Liszt: Musikalische Werke. Edited by Peter Raabe. Leipsig: Breitkof\&Härtel, 1922. https://imslp.org/wiki/Ihr_Glocken_von_Marling,_S.328 (Liszt,_Franz).

- Franz Liszt: Musikalische Werke. Edited by Peter Raabe. Leipzig: Breitkof\&Härtel, 1922. https://imslp.org/wiki/Verlassen,_S.336_(Liszt,_Franz).

MacDonald, Malcolm. Brahms. 1st American ed. Master Musicians Series. New York: Schirmer Books, 1990. http://www.gbv.de/dms/hbz/toc/ht004758411.PDF.

Musgrave, Michael. The Music of Brahms. Oxford: Clarendon Press, 1994.

http://www.gbv.de/dms/bowker/toc/9780198164012.pdf.

Newman, Ernest. Hugo Wolf. New York: Dover Publications, 1966.

Notley, Margaret Anne. Lateness and Brahms: Music and Culture in the Twilight of Viennese Liberalism. AMS Studies in Music. Oxford; Oxford University Press, 2007. http://catdir.loc.gov/catdir/toc/ecip0610/2006008848.html.

Okuda, Sue S. “Brahms's Late Song Style: The Vier Ernste Gesänge, Op.121.” M.A. thesis, California State University, 1981.

Pop Tug. "Musical Analysis: Wolf's 'In Dem Schatten Meiner Locken.'” Accessed March 5, 2019. https://poptug.com/musical-analysis-wolfs-in-dem-schatten-meiner-locken/.

Rohr, Deborah Adams. "Brahms's Metrical Dramas: Rhythm, Text Expression, and Form in the Solo Lieder." Ph.D., University of Rochester, Eastman School of Music, 1997. http://search.proquest.com/pqdtglobal/docview/304434325/abstract/9380AC6ED1604253PQ/8. 
Ross, Alex. "Blessed Are the Sad: Late Brahms." In Listen to This, 293-311. New York, NY: Farrar, Straus,\& Giroux, 2010.

Said, Edward W. On Late Style: Music And Literature Against the Grain. Vintage Series. New York: Vintage Books, 2007. https://books.google.com/books?id=2pOODQAAQBAJ.

_. Music at the Limits. New York: Columbia University Press, 2008. http://catdir.loc.gov/catdir/toc/ecip079/2007002276.html.

Sams, Eric. The Songs of Hugo Wolf. 1st Midland ed. London: Methuen and Co LTD, 1961. http://www.gbv.de/dms/bowker/toc/9780253207906.pdf.

—. The Songs of Johannes Brahms. New Haven, Conn.: Yale University Press, 2000.

Sams, Eric. Brahms Songs. BBC Music Guides. London: BBC, 1972.

—_. "Wolf, Hugo | Grove Music." Accessed March 29, 2019. https://doi.org/10.1093/gmo/9781561592630.article.52073.

Sams, Eric, and Susan Youens. Wolf, Hugo. Oxford University Press, 2001. http://www.oxfordmusiconline.com/grovemusic/view/10.1093/gmo/9781561592630.001.0001/o mo-9781561592630-e-0000052073.

Schmid, Mark-Daniel. "Book Review: Brahms and the German Spirit.” The Historian 68, no. 1 (2006): 180-81.

Schoenberg, Arnold. Style and Idea. New York: Philosophical Library, 1950.

Stark, Lucien, and Johannes Brahms. A Guide to the Solo Songs of Johannes Brahms. Bloomington: Indiana University Press, 1995.

Van Rij, Inge. Brahms's Song Collection. Cambridge: Cambridge University Press, 2006.

Wolf, Hugo. Michelangelo-Lieder. Translated by John Bernhoff. 3155th ed. Leipsig: C.F. Peters, 1908. https://imslp.org/wiki/Michelangelo-Lieder_(Wolf,_Hugo).

—. Spanisches Liederbuch. Mainz: Schott Music, 1891. https://imslp.org/wiki/Spanisches_Liederbuch_(Wolf,_Hugo).

Youens, Susan. Hugo Wolf: The Vocal Music. Princeton, N.J.: Princeton University Press, 1992. http://catdir.loc.gov/catdir/toc/prin031/91045446.html. 